\title{
WestVirginiaUniversity
}

THE RESEARCH REPOSITORY @ WVU

Graduate Theses, Dissertations, and Problem Reports

2019

\section{Soil Health Assessment in Reclaimed Mine Soils}

Katie Danielle Stutler

kdstutler@mix.wvu.edu

Follow this and additional works at: https://researchrepository.wvu.edu/etd

Part of the Natural Resources and Conservation Commons, and the Other Environmental Sciences

Commons

\section{Recommended Citation}

Stutler, Katie Danielle, "Soil Health Assessment in Reclaimed Mine Soils" (2019). Graduate Theses, Dissertations, and Problem Reports. 4021.

https://researchrepository.wvu.edu/etd/4021

This Thesis is protected by copyright and/or related rights. It has been brought to you by the The Research Repository @ WVU with permission from the rights-holder(s). You are free to use this Thesis in any way that is permitted by the copyright and related rights legislation that applies to your use. For other uses you must obtain permission from the rights-holder(s) directly, unless additional rights are indicated by a Creative Commons license in the record and/ or on the work itself. This Thesis has been accepted for inclusion in WVU Graduate Theses, Dissertations, and Problem Reports collection by an authorized administrator of The Research Repository @ WVU. For more information, please contact researchrepository@mail.wvu.edu. 
West VirginiaUniversity
THE RESEARCH REPOSITORY @ WVU

Graduate Theses, Dissertations, and Problem Reports

2019

Soil Health Assessment in Reclaimed Mine Soils

Katie Danielle Stutler

Follow this and additional works at: https:// researchrepository.wvu.edu/etd

Part of the Natural Resources and Conservation Commons, and the Other Environmental Sciences Commons 


\title{
SOIL HEALTH ASSESSMENT IN RECLAIMED MINE SOILS
}

\author{
Katie Danielle Stutler
}

Thesis submitted

to the Davis College of Agriculture, Natural Resources \& Design at West Virginia University

in partial fulfillment of the requirements for the degree of

Master of Science

in

Environmental Soil \& Water Sciences

Eugenia M. Pena-Yewtukhiw, Ph.D., Chair

Jeffrey Skousen, Ph.D.

Nicole Waterland, Ph.D.

Department of Plant and Soil Sciences

Morgantown, West Virginia

2019

Keywords: soil health, mine soils

Copyright 2019 Katie Danielle Stutler 


\title{
ABSTRACT \\ SOIL HEALTH ASSESSMENT IN RECLAIMED MINE SOILS
}

\begin{abstract}
Katie Stutler
West Virginia is one of the top coal-producing states in the nation, which has resulted in over 500,000 acres of highly disturbed, anthropogenic mine soils caused by surface mining. Mine soils are often rocky and contain low organic matter content, low plant-available nutrients, and toxic metals, which could result in poor soil health and low productivity. Soil health has been defined as the continued capacity of soil to function as a living ecosystem that sustains plants, animals, and humans. It is assumed that with time since reclamation, mine soil properties and related functions may change, and soil health will improve due to the process of soil development. The objectives of this study were to evaluate and compare NRCS Soil Quality Test Kit measurements to standard laboratory and field methods; to assess and compare soil health related properties also called indicators, plant diversity and productivity in reclaimed mine soils of different ages; and to assess mine soil health related to time since reclamation. The hypotheses were that NRCS Quality Test Kit measurements would yield comparable results to standard methods; that time since reclamation would positively influence soil properties related to soil health as well as plant productivity; and that response to fertilization management would be an indicator of soil health. Four West Virginia reclaimed mine soils were selected for this study based on age: WV32 -32 years, WV16 -16 years, WV11 -11 years, and WV2 -2 years. Three experiments were designed to test the hypotheses: Experiment I compared NRCS and standard methods in assessing soil health indicators on reclaimed mine sites; Experiment II compared the soil health indicators between WV16, WV11, and WV2 sites using 50 soil sampling points per site; Experiment III compared the effect of management (fertilization) on different mine soil health indicators and biomass production. For Experiment I, soil bulk density (BD), wet aggregate stability (WA), slaking, $\mathrm{pH}$, electrical conductivity (EC), soil respiration, and saturated hydraulic conductivity (saturated water infiltration, Ks) were measured using the NRCS Soil Quality Test Kit and standard laboratory procedures on all sites. The results indicated that measurements made with the NRCS Soil Quality Test Kit compared to those obtained with standard research laboratory methods, yielded statistically comparable results for saturated hydraulic conductivity (NRCS: $0.117 \mathrm{~cm} \mathrm{~min}^{-1}$; Standard: $0.114 \mathrm{~cm} \mathrm{~min}^{-1}$ ), for $\mathrm{pH}$ (NRCS: 6.4; Standard: 6.4), and for soil respiration (NRCS: $40.4 \mathrm{lb} \mathrm{CO}_{2}-\mathrm{C} \mathrm{ac}^{-1}$ day $^{-1}$; Standard: $50.6 \mathrm{lb} \mathrm{CO}_{2-}$ $\mathrm{C} \mathrm{ac}^{-1}$ day $^{-1}$ ). However, NRCS measured BD (NRCS: $1.30 \mathrm{Mg} \mathrm{m}^{-3}$; Standard: $1.46 \mathrm{Mg} \mathrm{m}^{-3}$ ), and NRCS measured EC (NRCS: $0.113 \mathrm{dS} \mathrm{m}^{-1}$; Standard: $0.227 \mathrm{dS} \mathrm{m}^{-1}$ ) showed similar trends to the standard methods, but tended to underestimate values. There was an effect of time since reclamation on the performance of NRCS Soil Quality Test kit as compared to standard methods. For Experiment II, soil health indicators (BD, aggregate stability, $\mathrm{pH}, \mathrm{EC}$, bioavailable nutrients) and vegetation surveys conducted using standard field and laboratory methods showed significant differences on surface soil $(0-15 \mathrm{~cm})$ health indicators. Wet aggregation and BD improved with time since reclamation, with higher water-stable aggregates and lower BD observed for WV16 $\left(6.1 \mathrm{~mm} ; 1.46 \mathrm{Mg} \mathrm{m}^{-3}\right)$ and WV11 $\left(5.8 \mathrm{~mm} ; 1.47 \mathrm{Mg} \mathrm{m}^{-3}\right)$ compared to WV2 $\left(5.7 \mathrm{~mm}\right.$; $\left.1.51 \mathrm{Mg} \mathrm{m}^{-3}\right)$. Soil $\mathrm{pH}$ was lower on WV11 (5.8), which related to lower SOM (42.2 $\left.\mathrm{mg} \mathrm{kg}^{-1}\right)$ compared to WV2 (52.8 $\left.\mathrm{mg} \mathrm{kg}^{-1}\right)$ and WV16 (55.1 $\left.\mathrm{mg} \mathrm{kg}^{-1}\right)$. Vegetation varied
\end{abstract}


between sites, with WV2 containing more forbs (36\%), WV11 containing more grasses (50\%), and WV16 containing less variation between legumes (31\%), forbs (18\%), and grasses $(39 \%)$. Experiment III (with or without urea fertilization) was conducted using a completely randomized factorial block design (time of application $\mathrm{x}$ urea application rate $\mathrm{x}$ replications/blocks). Results indicated that urea application positively affected biomass production on the youngest (WV2) and oldest sites (WV16), with a continuous increase in biomass with each harvest (regrowth). Site WV16 had the highest amount of biomass accumulation (4.14 $\left.\mathrm{Mg} \mathrm{ha}^{-1}\right)$ compared to WV2 $\left(2.86 \mathrm{Mg} \mathrm{ha}^{-1}\right)$ and WV11 (2.54 Mg ha $\left.{ }^{-1}\right)$ by the end of the study in fall 2018, as expected with increased soil development with time since reclamation. In summary, this study increased our knowledge of suitable methods to be used in the assessment of soil health in mine soils by determining that the NRCS Soil Quality Test Kit methods can be suitable in mine soils with adjustments to some measurement processes. This study also increased our knowledge in the effect of time on disturbed soils, and the potential for productivity on these reclaimed areas. The results of this research will expand understanding on reclaimed mine soil health and will aid in determining best future land use post-mining. 


\section{ACKNOWLEDGEMENTS}

First, I would like to thank Dr. Eugenia Pena-Yewtukhiw, the chair of my committee, for all of her time, support and patience throughout my time as her graduate student. I am fortunate to have called her my graduate advisor, as well as being able to now call her a life-long friend in and out of the academic realm. She never let me give up, and was always there for me no matter the time day or night. I would like to thank Dr. Jeffrey Skousen and Dr. Nicole Waterland, my committee members, not only for their time, but for their wisdom and much needed input throughout the process of my research. I would also like to thank Dr. James Thompson for always pushing me to be my best, and for truly guiding me toward my love of soil science and pedology. Dr. John Grove (University of Kentucky) and Dr. Domingo Mata-Padrino also supported my research by providing expertise and help whenever they saw the opportunity. I am truly blessed to have had such a wonderful support system within academia to guide me along this wild and wonderful journey.

I was fortunate enough to have many helping hands during my field sampling and laboratory work. I would like to thank the undergraduates who took time out of their busy summers and semesters to help me keep my research on schedule. I would not have been able to complete as much as I did without James McCain, Justice Price, Taylore Brown, Erin Mates, Dominic Ragusa and Connor Portner. They were always eager to learn and were a complete joy to work with.

Last, but certainly not least, I want to thank my family. My mother, Laura Stutler, has always supported me along with all of my dreams, no matter what they might be. My father, Daniel Stutler, has taught me to challenge myself and to never back down, even when times get tough. My sisters, Cristin and Nicki, have supported me since I can remember, and never forget to give me an extra dose of sisterly love. I'd also like to thank my boyfriend, Carter Smith, for his unconditional love and support, and the late-night library dates and infinite amount of food he delivered to my office and lab. The little things really made all the difference. I am grateful and beyond blessed to have so much love and support surrounding me. Thank you all. 


\section{TABLE OF CONTENTS}

CHAPTER 1. INTRODUCTION AND JUSTIFICATION ...................................................... 1

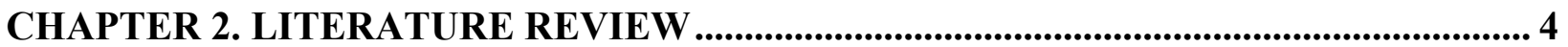

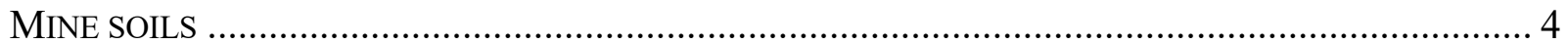

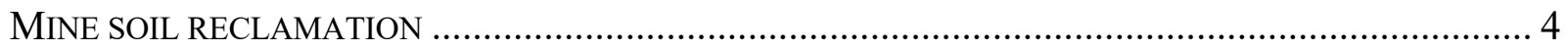

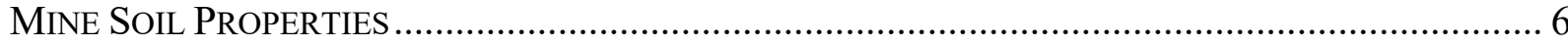

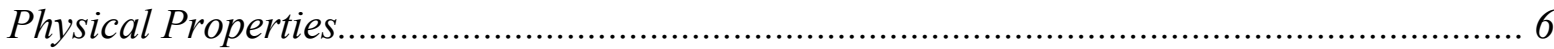

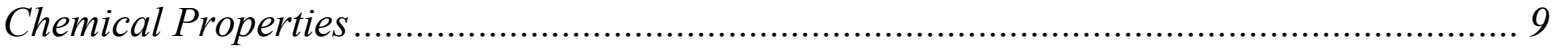

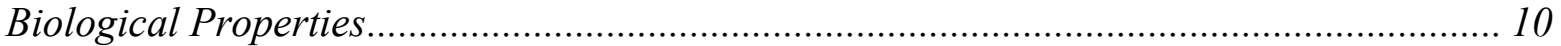

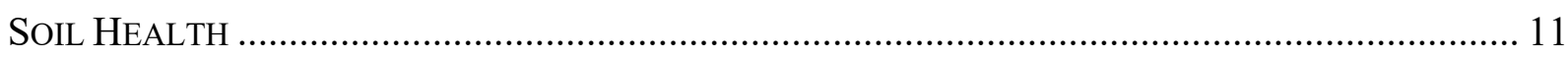

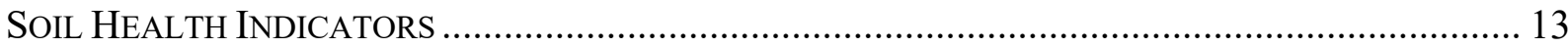

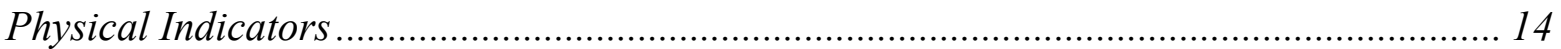

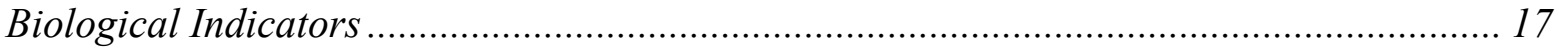

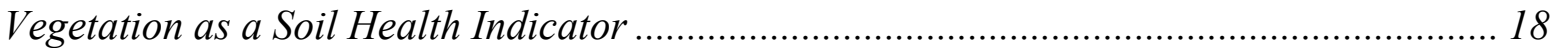

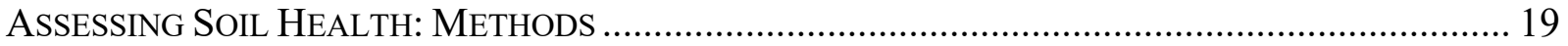

STUDY EXPERIMENTS’ OBJECTIVES AND HYPOTHESES ........................................................ 22

Experiment I: Soil health indicator characterization using the NRCS Soil Quality Test Kit

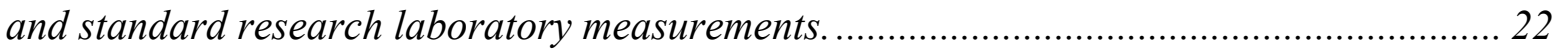

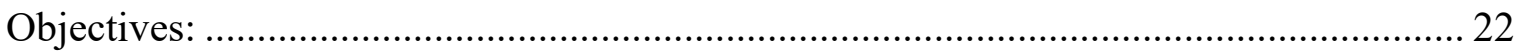

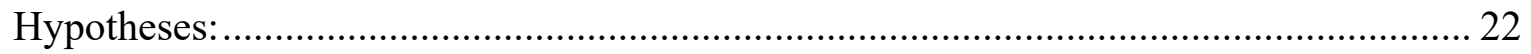

Experiment II: Soil health analysis based on plant indicators.......................................... 22

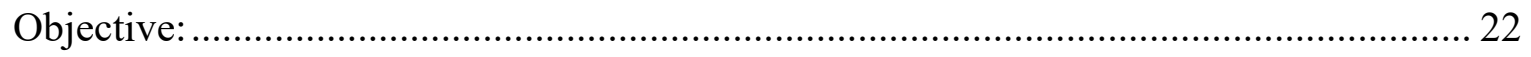




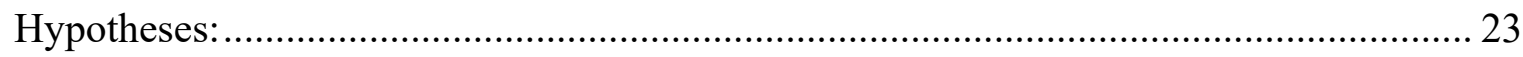

Experiment III: Soil health response to management practices..................................... 23

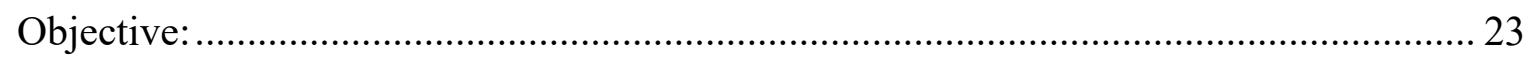

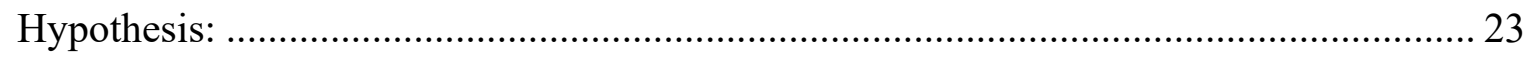

CHAPTER 3. MATERIALS AND METHODS.................................................................... 24

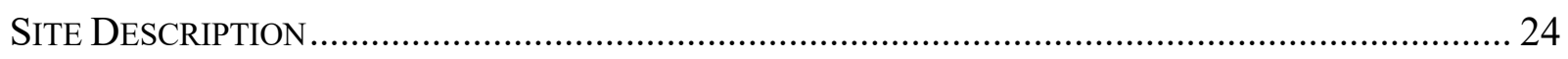

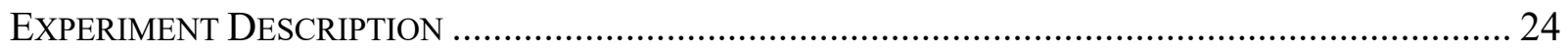

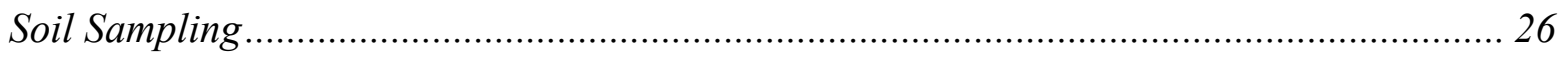

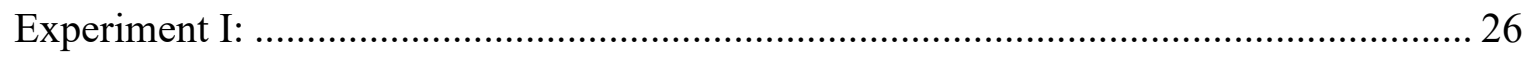

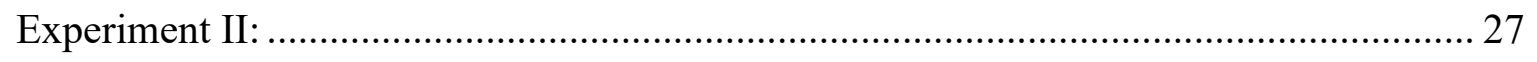

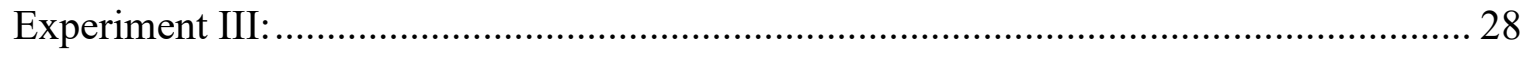

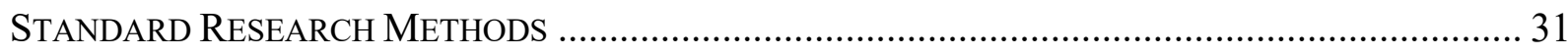

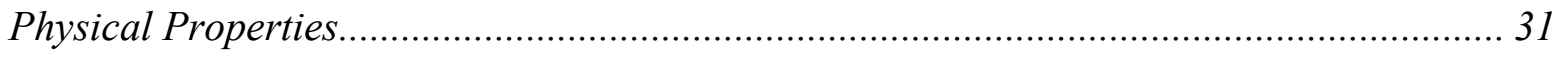

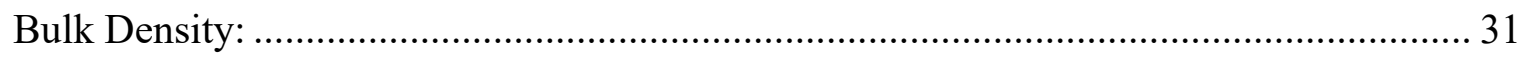

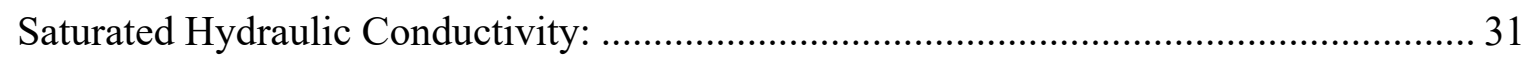

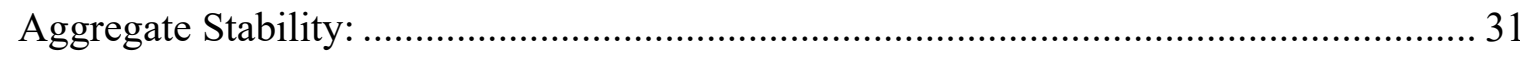

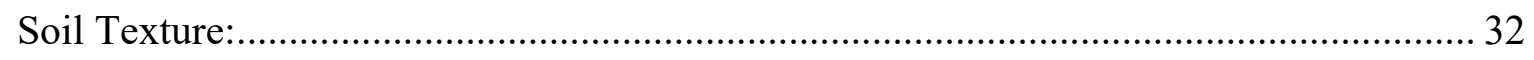

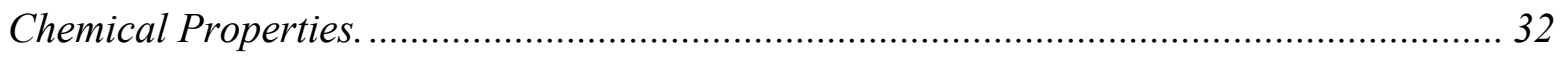

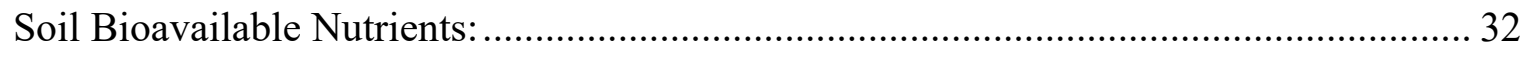

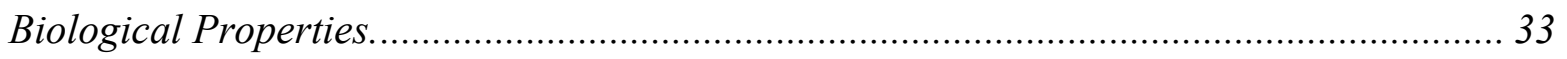

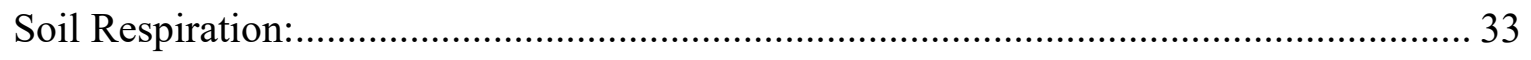

NRCS SOIL QuALITY TEST Kit MethodS .................................................................. 33

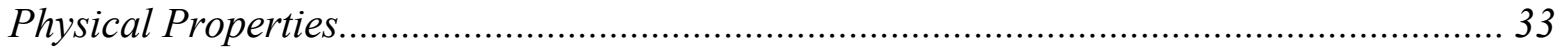




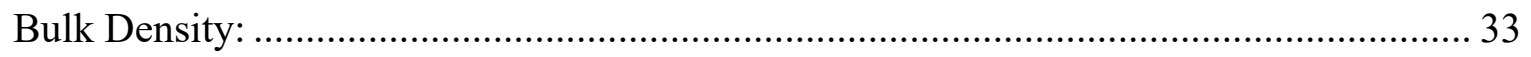

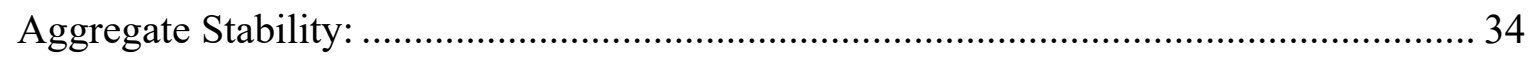

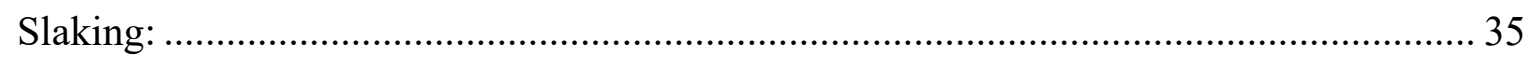

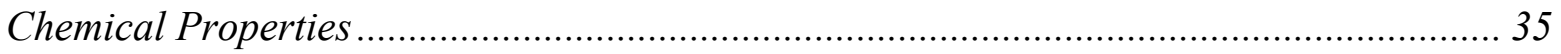

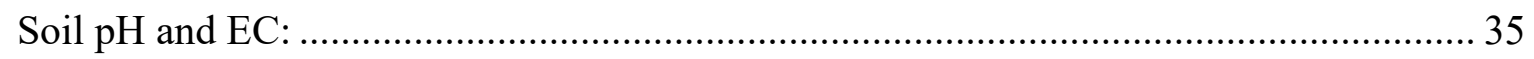

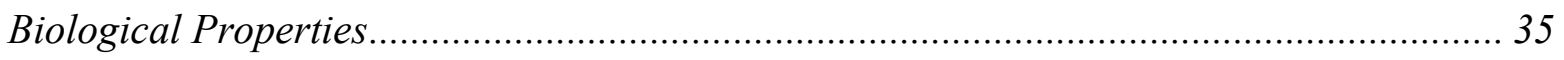

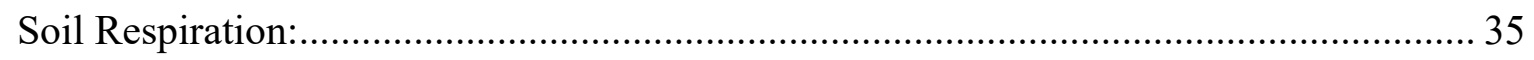

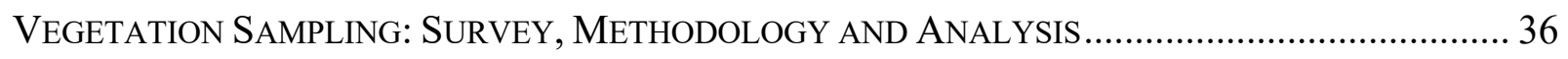

EXPERIMENTAL DESIGN AND DATA ANALYSIS ............................................................. 36

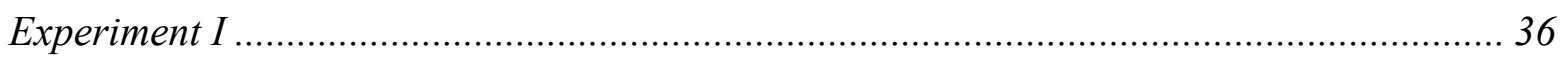

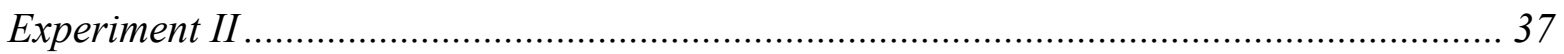

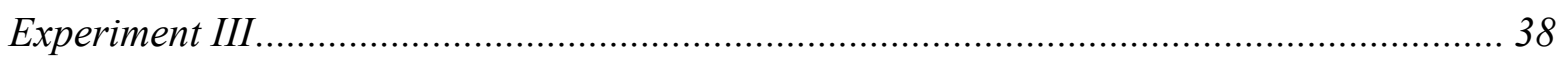

CHAPTER 4. RESULTS AND DISCUSSION ........................................................... 39

EXPERIMENT I: SOIL QUALITY TEST Kit EVALUATION .................................................... 39

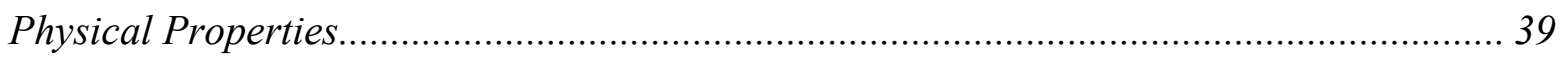

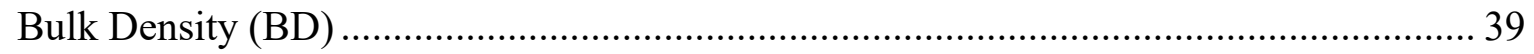

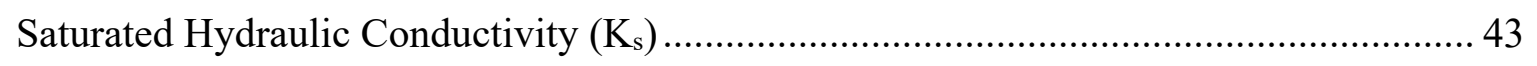

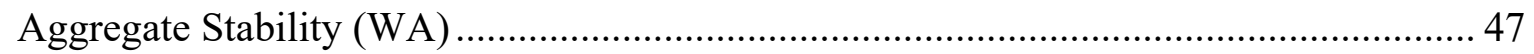

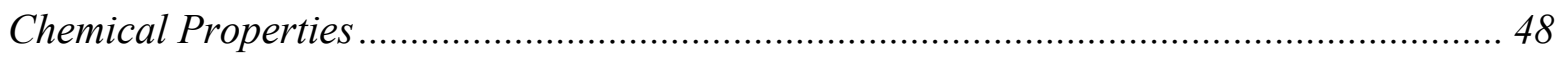

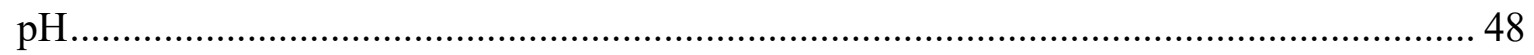

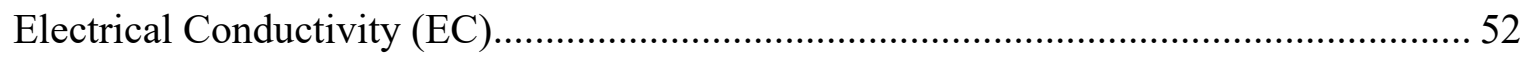

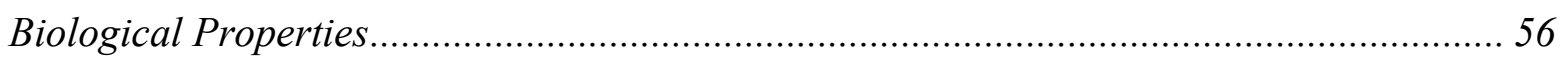

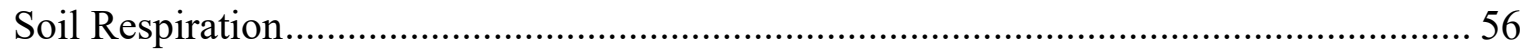


EXPERIMENT II: TIME SinCE RECLAMATION AND SOIL HEALTH.......................................... 57

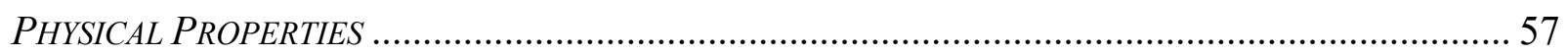

Coarse Fragments and Fines ............................................................................... 57

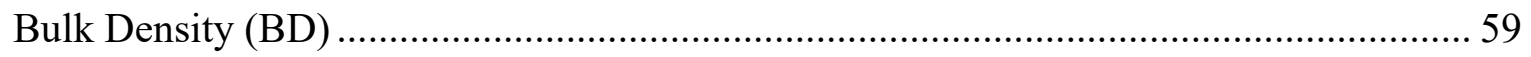

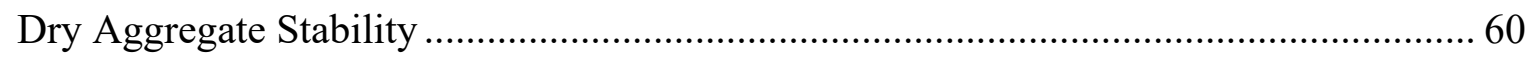

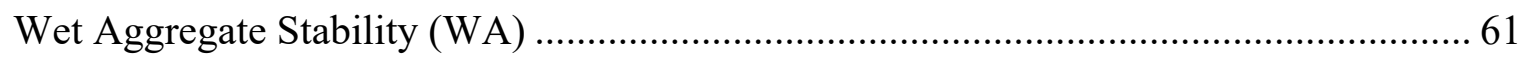

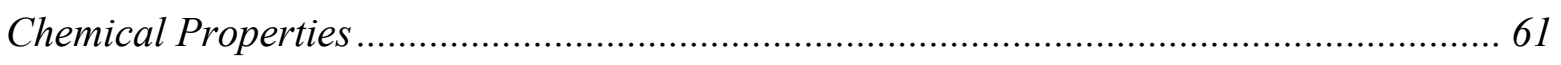

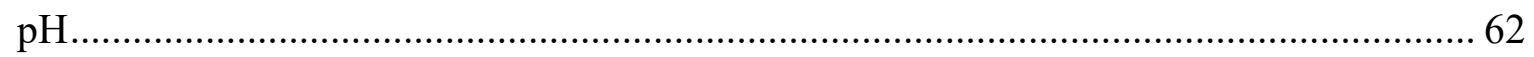

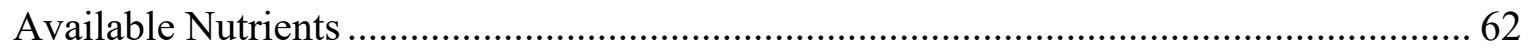

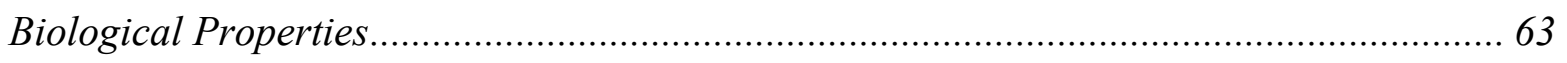

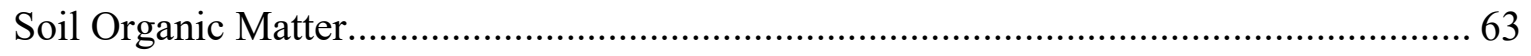

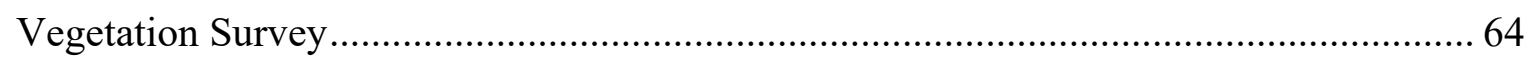

EXPERIMENT III: TIME SinCE RECLAMATION AND RESPONSE TO MANAGEMENT ..................... 67

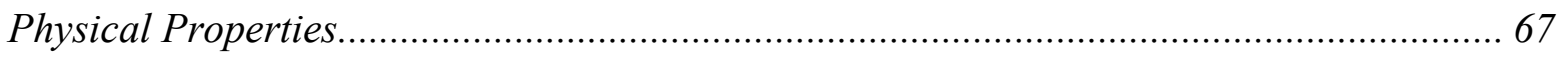

Coarse Fragments and Fines, and Particle Size Distribution (Texture) characterization .. 67

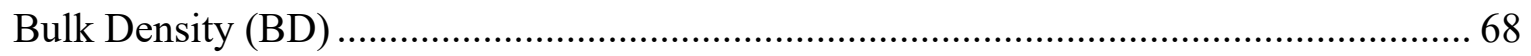

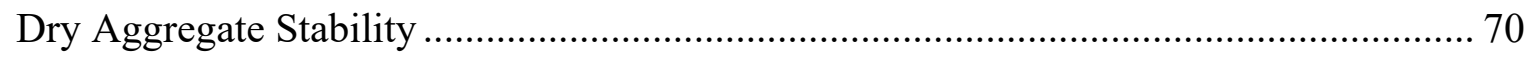

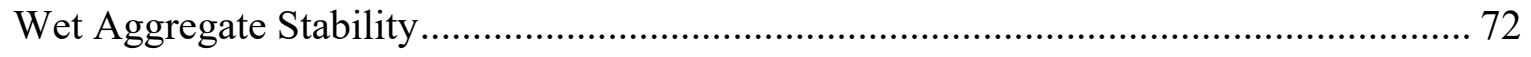

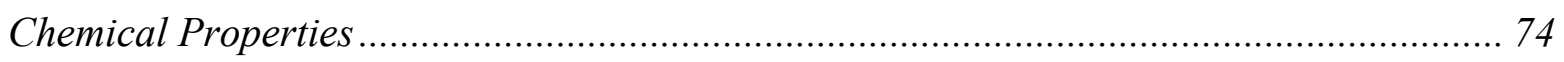

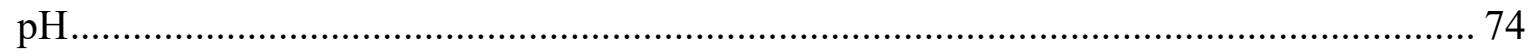

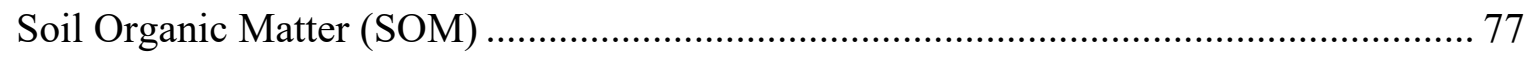

Bioavailable Nutrients ..................................................................................... 78

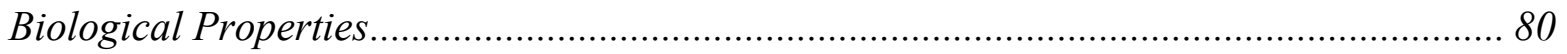




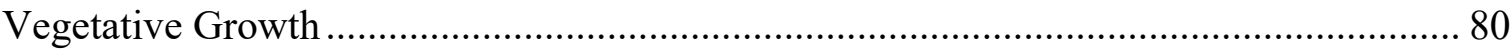

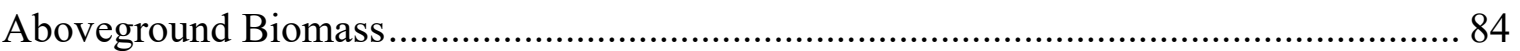

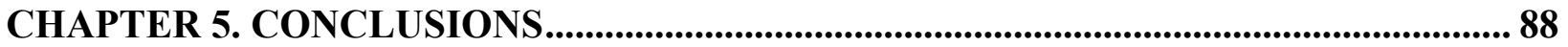

REFERENCES............................................................................................................................ 92

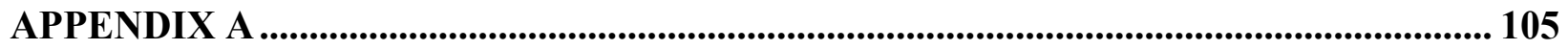

APPENDIX B ........................................................................................................................ 116

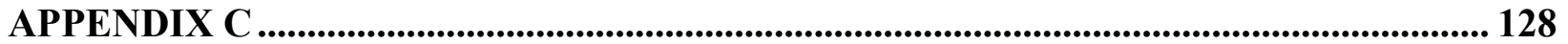




\section{LIST OF TABLES}

Table 1. Tier 1 soil health indicators and methods to be assessed (updated 10/8/2018) 21

Table 2. Average annual rainfall in Morgantown, WV for 2017 and 2018 (data taken from U.S. Climate Data, 2019). 24

Table 3. Differences in soil bulk density $\left(\mathrm{mg} \mathrm{m}^{-3}\right)$ obtained with standard and NRCS methods between sites at an $\alpha$ level of 0.10 .

Table 4. Differences in saturated hydraulic conductivity $\left(\mathrm{cm} \mathrm{min}^{-}\right)$obtained with standard and NRCS methods between sites at an $\alpha$ level of 0.10 .

Table 5. Differences in aggregate stability obtained with standard and NRCS methods between sites at an $\alpha$ level of 0.10 . 48

Table 6. Differences in ph values obtained with standard and NRCS methods between sites at an $\alpha$ level of 0.10 . 50

Table 7. Differences in electrical conductivity (ec in $\mathrm{ds} \mathrm{m}^{-1}$ ) obtained with standard and NRCS methods between sites at an $\alpha$ level of 0.10 . 55

Table 8. Differences in respiration obtained with standard and NRCS methods between sites at an $\alpha$ level of 0.10 57

Table 9. Differences in coarse fragments and fine particles ( $\%$ by weight) obtained with standard methods between sites at an $\alpha$ level of 0.10 . 58

Table 10. Differences in texture $\left(\mathrm{mg} \mathrm{kg}^{-1}\right)$ obtained with standard methods between sites at an $\alpha$ level of 0.10 . 59 
Table 11. Differences in $0-15 \mathrm{~cm}$ uncorrected and rock corrected soil bulk density $\left(\mathrm{mg} \mathrm{m}^{-3}\right)$.. 60

Table 12. Differences in $0-15 \mathrm{~cm}$ dry aggregate stability (mwd) at an $\alpha$ level of 0.10. 61

Table 13. Differences in $0-15 \mathrm{~cm}$ ph between sites at an $\alpha$ level of 0.10 . 62

Table 14. Differences in mehlich iii extracted bioavailable nutrients (mg kg-1) between sites at an $\alpha$ level of 0.10 63

Table 15. Differences in soil organic matter $\left(\mathrm{g} \mathrm{kg}^{-1}\right)$ obtained with standard methods between sites at an $\alpha$ level of 0.10 . 64

Table 16. Differences in vegetation diversity obtained with standard methods between sites at an $\alpha$ level of 0.10 . 65

Table 17. Effect of site and year on coarse and fine fragments, and texture (sand, silt and clay).

Table 18. Effect of site on rock corrected bulk density $\left(\mathrm{mg} \mathrm{m}^{-3}\right)$.

Table 19. Effect of fertilizer treatment, site and year on corrected BD, dry aggregate (DA) and wet aggregate (WA) mean weight diameter (MWD). 71

Table 20. Effect of year and site on dry aggregate (DA) and wet aggregate (WA) stability (MWD) (mm). 72

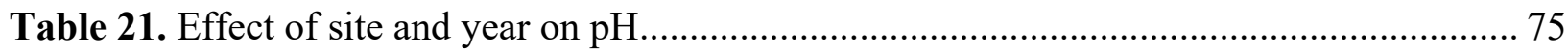

Table 22. Effect of fertilizer treatment, site and year on $\mathrm{pH}$ and soil organic matter (SOM in $\mathrm{mg}$ $\left.\mathrm{kg}^{-1}\right)$ 75

Table 23. Effect of site and year on bioavailable Al, Ca, Fe, K, Mg, Na, P, and $\mathrm{Zn}\left(\mathrm{mg} \mathrm{kg}^{-1}\right) . \underset{\text { xi }}{79}$ 
Table 24. Effect of site and treatment on bioavailable $\mathrm{Mg}$ and $\mathrm{Zn}\left(\mathrm{mg} \mathrm{kg}^{-1}\right)$.

Table 25. Descriptive statistics and analysis of variance for initial, or spring, plant diversity

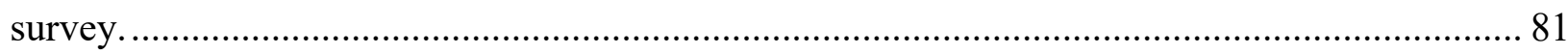

Table 26. Descriptive statistics and analysis of variance for second, or fall, plant diversity survey 83

Table 27. Descriptive statistics and analysis of variance for biomass .................................. 85 


\section{LIST OF FIGURES}

Figure 1. Satellite view of the study sites located in monongalia county: WV2, WV11, WV16,

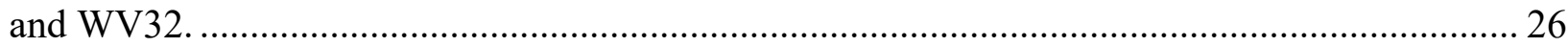

Figure 2. Satellite image of reclaimed WV2 mine site with experiment III block locations. Red indicates plots fertilized with urea application. Yellow indicates control plots.

Figure 3. Satellite image of WV11 reclaimed mine site with experiment III block locations. Red plots were fertilized with urea application. Yellow were control plots. 29

Figure 4. Satellite image of WV16 reclaimed mine site with experiment III block locations. Red indicates plots fertilized with urea application. Yellow indicates control plots. 30

Figure 5. Satellite image of reclaimed WV32 mine site used in experiment I.

Figure 6. Overall (all sites) comparison of soil bulk density obtained with the standard and NRCS methods.

Figure 7. Comparison of soil bulk density obtained with the standard and NRCS methods by site: 7a. WV2, 7b. WV11, 7c. WV16, and 7d. WV32.

Figure 8. Overall (all sites) comparison of saturated hydraulic conductivity obtained with the standard and NRCS methods.

Figure 9. Comparison of saturated hydraulic conductivity obtained with the standard and NRCS

methods by site: 9a. WV2, 9b. WV11, 9c. WV16, and 9d. WV32 46

Figure 10. Overall (all sites) comparison of $\mathrm{pH}$ obtained with the standard and NRCS methods.

Figure 11. Comparison of $\mathrm{pH}$ obtained with the standard and NRCS methods by site: 11a. WV2, 
11b. WV11, 11c. WV16, and 11d. WV32.

Figure 12. Overall (all sites) comparison of EC obtained with the standard and NRCS methods.

Figure 13. Comparison of EC obtained with the standard and NRCS methods by site: 13a. WV2,

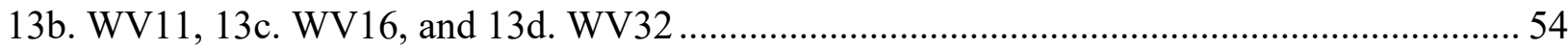

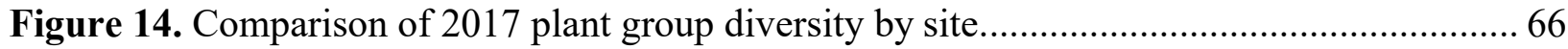

Figure 15. Comparison of 2018 plant group diversity by site.............................................. 66

Figure 16. Comparison of aboveground biomass by site, year, and harvest........................... 86

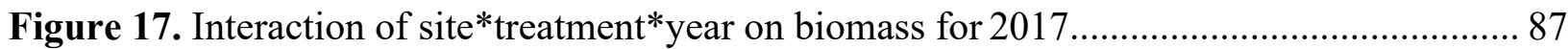

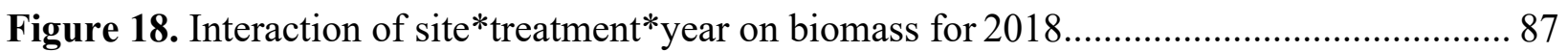




\section{LIST OF APPENDICES}

Figure A1a. NRCS pedon description of WV32 mine site. 105

Figure A1b. Continued NRCS pedon description of WV32 mine site. 106

Figure A2a. NRCS pedon description of WV16 mine site. 107

Figure A2b. Continued NRCS pedon description of WV16 mine site. 108

Figure A3a. NRCS pedon description of WV11 mine site 109

Figure A3b. Continued NRCS pedon description of WV11 mine site. 110

Figure A4a. NRCS pedon description of WV2 mine site.

Figure A4b. Continued NRCS pedon description of WV2 mine site.

Table A1. Experiment I descriptive statistics for all measured indicators across sites. 113

Table A2. Bulk density (BD in $\mathrm{g} \mathrm{cm}^{-3}$ ) descriptive statistics using the NRCS Soil Quality Test

Kit method and standard method for all four sites. 113

Table A3. Saturated hydraulic conductivity (Ks in $\mathrm{cm} \mathrm{min}^{-}$) descriptive statistics using the NRCS Soil Quality Test Kit method and standard method for all four sites.

Table A4. $\mathrm{pH}$ descriptive statistics using the NRCS Soil Quality Test Kit method and standard method for all four sites. 114

Table A5. Electrical conductivity (EC in $\mathrm{ds}^{-}$) descriptive statistics using the NRCS Soil Quality Test Kit method and standard method for all four sites.

Table A6. Respiration descriptive statistics using the NRCS Soil Quality Test Kit method and standard method for all four sites. 115 
Figure A5. Overall (all sites) comparison of respiration obtained with the standard and NRCS

methods.

115

Table B1. Experiment II physical property descriptive statistics among all sites.................. 116

Table B2. Experiment II chemical property descriptive statistics among all sites .................. 117

Table B3. Experiment II vegetation survey descriptive statistics among all sites .................. 118

Table B4. Experiment II physical properties descriptive statistics site WV2 ........................ 119

Table B5. Experiment II chemical properties descriptive statistics site WV2 ........................ 120

Table B6. Experiment II \% vegetation descriptive statistics WV2 .................................. 121

Table B7. Experiment II physical properties descriptive statistics site WV11 ..................... 122

Table B8. Experiment II chemical properties descriptive statistics WV11 .......................... 123

Table B9. Experiment II \% vegetation descriptive statistics WV11 .................................... 124

Table B10. Experiment II physical properties descriptive statistics site WV16 .................... 125

Table B11. Experiment II chemical properties descriptive statistics WV16 ........................ 126

Table B12. Experiment II \% vegetation descriptive statistics WV16 ................................. 127

Table C1. Descriptive statistics and analysis of variance for particle size distribution............ 128

Table C2. Descriptive statistics and analysis of variance for available nutrients .................. 129

Table C3. Descriptive statistics and analysis of variance for available nutrients .................... 130 


\section{CHAPTER 1. INTRODUCTION AND JUSTIFICATION}

West Virginia is one of the top coal-producing states in the nation, which has resulted in over 500,000 acres of highly disturbed, anthropogenic mine soils caused by surface mining. West Virginia was ranked the largest coal producer east of the Mississippi, and the second largest coal producer in the nation with $11 \%$ of the total U.S. coal production in 2016 (EIA, 2017). The state's economy has historically revolved around coal mining dating back to the mid-1800s. Coal slowly began being used by blacksmiths and replaced charcoal as fuel for heat sources in the early 1800 s, and eventually attracted more attention over time. In 1914, large-scale surface mining began and became a major method of mining in West Virginia (WVGES, 2017). Several mining methods are now used throughout the state, which include both underground and surface mining. In 2015, a recorded 231 surface mines were in operation in West Virginia, producing a total of 18.9 million tons of coal (WVMHST, 2015).

Over the last 150 years, the coal industry has provided the state with employment opportunities, as well as large amounts of fossil fuels for the nation. Coal mining has declined with dwindling resources and an increased interest for cleaner fuel sources such as natural gas, however the mining over the past 100 years has impacted the state's topography and natural ecosystems. As of 1977, the Surface Mining Control and Reclamation Act (SMCRA) was passed to help reduce environmental degradation caused by coal mining, specifically soil and water quality. SMCRA states that mine operators must designate a suitable and achievable land use that should provide ecosystem services and societal needs post-mining (Skousen and Zipper, 2014). Some of these reclaimed areas are now nearly level to gently sloping and landowners are eager to use these areas for economic opportunities such as crop production and grazing.

However, mine soils are believed to be low productivity soils that are often rocky, contain 
low organic matter content, low plant-available nutrients and high heavy metal content which result in poor conditions of soil health and plant productivity. After reclamation, mine soils are highly disturbed with altered soil physical and chemical properties (e.g. bulk density, coarse fragment composition, $\mathrm{pH}$, and nutrient status) that are not typically found in natural or agricultural soils. These altered soil properties can negatively impact the soil heath, or the ability to function and to sustain ecosystem productivity.

Soil health is defined as the continued capacity of soil to function as a vital living ecosystem that sustains plants, animals, and humans (USDA-NRCS, 2017). Therefore, soil health can determine the sustainability of the natural environment and agricultural lands. Healthy soils exhibit physical, chemical and biological properties that maintain and sustain a given land use. Physical support, water movement, nutrient supply, and filtration of pollutants are amongst the vital functions of soil (Laishram et al. 2012). Understanding current soil health is important when determining land uses and best management practices for specific land uses, such as agriculture or forestry. Assessing soil health and understanding local conditions and needs are necessary when planning for prospective land uses. However, assessing soil health is a challenge because it cannot be measured directly, but is quantified through specified soil indicators such as bulk density, infiltration, $\mathrm{pH}$, soil organic matter, etc. based on location and land use requirements (Riley, 2001). Soil health indicators are measurable soil attributes that influence the capacity of soil to perform vital functions, and the most sensitive indicators are the most desired (Arshad and Martin, 2002). Soils affected by anthropogenic activity, such as reclaimed mine lands, are especially difficult to assess due to unnatural soil composition and pattern.

The Natural Resources Conservation Service (NRCS) under the United States Department of Agriculture (USDA) promotes soil health assessment using a landowner-friendly Soil Quality 
Test Kit which includes equipment and a list of eleven soil indicators and observations applicable to agricultural soils (USDA-NRCS, 2001). These eleven indicators include soil respiration, infiltration, bulk density, electrical conductivity, $\mathrm{pH}$, soil nitrate, aggregate stability, slaking, earthworm observation, soil physical observations (topsoil depth, root growth, penetration resistance and soil structure) and water quality tests (water electrical conductivity and nitrate/nitrite) to best assess and understand soil functions and processes, and their effects on soil health.

The Soil Quality Test Kit was developed by John Doran and associates from the Agricultural Research Service (ARS) in Lincoln, Nebraska. Test kit development and enhancement was continued through the Soil Quality Institute. The purpose of the Soil Quality Test Kit and list of soil health indicators is to allow farmers and landowners to easily measure physical, chemical, and biological soil properties, and to make interpretations on the soil's overall functions, processes, and health at their convenience (USDA, 1999). A Soil Quality Test Kit Guide was also developed to help with background information and interpretations for each soil indicator. The value of the NRCS Soil Quality Test Kit in assessing soil health in reclaimed mine soils, and how it would compare to standard scientific methods is unknown.

The objectives of this research are to assess the physical, chemical, and biological soil health indicators of different aged reclaimed mine soils using the NRCS Soil Quality Test Kit and standard scientific methods, as well as vegetation, to evaluate soil health and more easily predict suitable future land uses. This study will help to better assess and understand the evolution of soil health in reclaimed mine soils of various ages and the correlation between Soil Quality Test Kits and standard scientifically based field and laboratory methods. The acquired knowledge could result in the estimation of the potential of reclaimed mine soils for uses such as 
agriculture, grasslands, and forestry throughout West Virginia. With growing knowledge of soil development and health post-reclamation, an increase and successful adoption of land uses to mine soils could be achieved.

\section{CHAPTER 2. LITERATURE REVIEW}

\section{Mine soils}

Mine soils can be defined as anthropogenic soils formed on previously mined areas that may contain altered properties such as high rock fragment content, low clay contents, and variable chemical properties (Hearing et al. 2004). Unlike natural, undisturbed soils, mine soils are heavily influenced by human activity and therefore are morphologically different than the surrounding native soils (Sencindiver and Ammons, 2000). Mining type and location will have a great effect on mine soil development due to mining methods and underlying parent material.

In Appalachia, common surface coal mining techniques include contour stripping and mountaintop removal. Surface mining consists of stripping off the soil and parent material layers to access a coal seam. The material that is taken off, often referred to as overburden or minespoil, is set aside and is exposed to surface weathering conditions (Sencindiver and Ammons, 2000). This overburden is part of the material that will make up the mine soil, with the addition of topsoil. Once the coal seams are extracted, reclamation methods are then used to reshape and revegetate the landscape close to its original form.

\section{Mine soil reclamation}

Mine land reclamation is an activity that has been regulated since 1977, however, a detailed description of the threshold values for soil properties to be achieved after reclamation has never been described. The Surface Mining Control and Reclamation Act of 1977 (SMCRA) established 
a federal-to-state oversight system (Skousen and Zipper, 2014). This system allows the federal government to assign enforcement of a federal law to state agencies. SMCRA requires all mining companies to apply for a mining permit indicating all site characteristics, mining methods, and reclamation strategies post-mining.

Companies must make a statement of the condition of the land prior to mining which includes: (i) current uses of the land, (ii) capability of the land prior to mining (giving consideration to soil and foundation characteristics, topography, and vegetative cover), and (iii) productivity of the land prior to mining. A proposed land use following reclamation must be stated, along with utility and capacity of the land to support alternative uses (OSMRE, 2017).

Post-mining land uses may include agriculture, hay land and pasture, forest, wildlife habitat, biofuel crops, and developed land uses (industrial, commercial, residential) (Skousen and Zipper, 2014). Engineering techniques in mining and reclamation must also be stated including backfilling, soil stabilization, compacting, grading, and appropriate revegetation (OSMRE, 2017).

Once the mining process is complete, the reclamation process begins. The overburden that was previously set aside is then replaced and used to fill the landscape. Dozers and heavy machinery are then used for grading and replacement of topsoil to approximate original contour (AOC) (Skousen and Zipper, 2014). Topsoil substitute may be used if equally or more suitable than native topsoil. Successful establishment of vegetation is required for many post-mining land uses (Skousen and Zipper, 2014). Revegetation during reclamation typically consists of seeding with mixed grasses and legumes, which will then quickly establish a dense ground cover to reduce soil loss and erosion. Pioneer species, or the first species to colonize after an ecosystem disturbance, such as grasses, forbs (ragweed and goldenrod), vines, and shrubs (blackberry) will 
also begin to establish (Groninger et al., 2007). However, the equipment used for backfilling and grading often cause compaction of the topsoil which can limit air and water movement, as well plant development. The plants that are seeded during reclamation have shallow rooting depths, and are not as affected by the compaction compared to woody plants and trees (Skousen and Zipper, 2014).

\section{Mine Soil Properties}

Filling the previously mined area with overburden, exposes un-weathered rock to weathering processes on the surface which will begin to break down physically and chemically. Weathering of the overburden affects the acidity or alkalinity of the soil, and other physical and chemical properties. Indorante et al. (1992) found that texture, color, and $\mathrm{pH}$ of mine soils are the result of the specific overburden type and rate of weathering.

Common horizonations seen in mine soils include A-C or A-AC-C (Sencindiver and Ammons, 2000). Due to the soil's pedogenically young age, E and B horizons have not had time to form. The A horizons that form are young and typically thin. The formation process of mine soils is accelerated by the addition of topsoil and vegetation, as well as natural succession over time (Mukhopadhyay et al., 2014). Vegetation establishment, root systems and organic matter assist in soil structure development and darkening of the soil's color (Sencindiver and Ammons, 2000).

\section{Physical Properties}

Mine soils have been known to have high rock fragment content $>2 \mathrm{~mm}$ up to $70 \%$ due to the overburden and parent material being replaced after mining (Ciolkosz et al., 1985; Thurman and Sencindiver, 1986; Roberts, et al., 1988; Hearing et al., 2004). Mukhopadhyay et al. (2016) found that reclaimed mine sites had $>50 \%$ coarse fraction, which was a property not common in 
the natural soils existing at the sites before mining started. The amount of sand was also higher on mine sites compared to reference sites, which agrees with Roberts et al. (1988) who found sand content to be between 49-71\% depending on parent material. Ciolkosz et al. (1985) found that non-topsoiled mine soils in Pennsylvania ranging in age from 1 to 29 years since reclamation also had high rock fragment contents of 40 to $60 \%$ in the surface. Soils consisting of higher rock contents can have lower cation exchange capacity (CEC) and reduced water holding capacity (Sobek et al., 2000).

Bulk density is the ratio of dry soil mass $(\mathrm{g})$ to its total volume $\left(\mathrm{cm}^{3}\right)$. Bulk density can be affected by texture and particle density, organic matter, arrangement of particles, and structure of the soil (USDA, 1999). Bulk density has been recorded to be higher in mine soils than in natural soils. Total bulk density (including rock fragments) and corrected bulk density (adjusted for rock fragments) have shown to be higher in these disturbed soils due to heavy mining machinery and compaction during reclamation. Bendfeldt et al. (2001) found total bulk density to be $1.51 \mathrm{Mg}$ $\mathrm{m}^{3}$ in both control and amended mine soils in Virginia, whereas the corrected bulk density was significantly lower at $1.24 \mathrm{Mg} \mathrm{m}^{3}$ in the control, and $1.38 \mathrm{Mg} \mathrm{m}^{3}$ in the amended soil which was not a significant difference. Mine soils in Pennsylvania adjusted for loose rocks exhibited an average surface bulk density of $1.81 \mathrm{Mg} \mathrm{m}^{3}$ using the excavation method and $1.70 \mathrm{Mg} \mathrm{m}^{3}$ using a gamma probe according to Pedersen et al. (1980).

Mine soils in West Virginia have been recorded to have high bulk density (Thurman and Sencindiver, 1986; Thomas, et al., 2000; Chaudhuri et al., 2010). Two surface mine soils in Monongalia Co., WV were recorded to have bulk density values of $1.55-1.86 \mathrm{Mg} \mathrm{m}^{-3}$ (Thurman and Sencindiver, 1986) . Bulk density was also found to be significantly higher on mine sites 
$\left(1.62 \mathrm{Mg} \mathrm{m}^{3}\right)$ compared to agricultural soils $\left(<1.5 \mathrm{Mg} \mathrm{m}^{3}\right)$, indicating compaction from reclamation methods (Mukhopadhyay et al., 2016). The compaction of mine soil limits movement of water and air, and can reduce plant development and growth.

Aggregate stability is the measure of the integrity of a soil aggregate under outside forces (Hillel, 1982). Thomas et al. (2000) sampled four different aged mine soils in West Virginia and found that water-stable aggregation increased with age in mine soils, but had less water-stable aggregates than native soils. Wick et al. (2009) recorded similar findings in a chronosequence of reclaimed mine soils in Wyoming. Macroaggregate and microaggregates within macroaggregates increased with time since reclamation, whereas microaggregates decreased. Bendfeldt et al. (2001) found that control mine soils and mine soils amended with native topsoil and lime had $57 \%$ and $52 \%$ aggregate stability, respectively, which did not show significant differences.

Due to coarse fragments, textural differences and lack of organic matter, mine soils have lower water-holding capacity compared to natural soils (Pedersen et al., 1980). Thurman and Sencindiver (1986) recorded low porosity of $26-38 \%$ in mine soils, which results in limited water movement throughout the soil profile. These sites also had low water retention capacity of $0.07-$ $0.12 \mathrm{~kg} \mathrm{~kg}^{-1}$, and moderately low estimated hydraulic conductivity at $0.1-1 \mu \mathrm{m} \mathrm{s}^{-1}$. Roberts et al. (1988) also found greatly reduced water availability in mine soils due to high coarse fragment content with water retention values between .02 and $.04 \mathrm{~kg} \mathrm{~kg}^{-1}$, compared to soils consisting of only $<2 \mathrm{~mm}$ fraction with values of .09 and $0.13 \mathrm{~kg} \mathrm{~kg}^{-1}$. Pedersen et al. (1980) recorded values of water content in Pennsylvania mine soils between 3.66-6.83\%, and an average initial saturated hydraulic conductivity of $640 \mathrm{~mm} \mathrm{hr}^{-1}$ and final saturated hydraulic conductivity after 4 months of $298 \mathrm{~mm} \mathrm{hr}^{-1}$. Saturated hydraulic conductivity had large variability in these soils between the 
ten sites, which was contributed to the washing out of fine materials and erosion. Infiltration was also shown to be lower in mine soils $\left(3.3-28 \mathrm{~mm} \mathrm{hr}^{-1}\right)$ compared to natural soils $(53-421 \mathrm{~mm}$ $\mathrm{hr}^{-1}$ ). Bendfeldt et al. (2001) recorded values of total porosity in control and amended mine soils of $53 \%$ and $46 \%$, respectively.

\section{Chemical Properties}

Extractable $\mathrm{P}$ in mine soil surfaces was found to be between $64-78 \mathrm{mg} \mathrm{kg}^{-1}$, and $30-52$ $\mathrm{mg} \mathrm{kg}^{-1}$ two years later. Values of extractable Fe in the same sites were found to be between 1,700-3,500 $\mathrm{mg} \mathrm{kg}^{-1}$, and 5,500 - 9,100 $\mathrm{mg} \mathrm{kg}^{-1}$. Values of $\mathrm{Ca}, \mathrm{Mg}, \mathrm{K}$, and $\mathrm{Al}$ were found to be 1.8-2.3 cmolc kg-1, $1.3-2.5$ cmolc kg-1, $0.3-0.6 \mathrm{cmolc} \mathrm{kg}^{-1}$, and $0-0.7 \mathrm{cmolc} \mathrm{kg}^{-1}$, respectively (Roberts et al., 1988). Bendfeldt et al. (2001) found that extractable P decreased in control mine soils without amendments from $55 \mathrm{mg} \mathrm{kg}^{-1}$ to $32 \mathrm{mg} \mathrm{kg}^{-1}$ after 16 years, whereas mine soils amended with native topsoil and lime showed a nonsignificant decrease in extractable $\mathrm{P}$ from 40 $\mathrm{mg} \mathrm{kg}^{-1}$ to $32 \mathrm{mg} \mathrm{kg}^{-1}$. Within the same control site and 16 year period, $\mathrm{K}$ decreased from 0.20 cmolc $\mathrm{kg}^{-1}$ to $0.10 \mathrm{cmolc} \mathrm{kg}^{-1}, \mathrm{Mg}$ decreased from $3.44 \mathrm{cmolc} \mathrm{kg}^{-1}$ to $1.4 \mathrm{cmolc} \mathrm{kg}^{-1}$, and Ca decreased from $3.3 \mathrm{cmolc}^{-1}$ to $1.4 \mathrm{cmolc} \mathrm{kg}^{-1}$. Similar findings were recorded for the mine site amended with native topsoil and lime.

Soil $\mathrm{pH}$ is the measure of acidity or alkalinity in a soil on a scale from $0-14$, which is the measurement of hydrogen ion activity $\left[\mathrm{H}^{+}\right]$in a $1: 1$ soil water solution. Soil $\mathrm{pH}$ is dependent on the parent material and texture of the soil, and affects bioavailable nutrients and microorganism activity in the soil (USDA, 1999). The soil $\mathrm{pH}$ in mine soils is highly variable depending on the overburden parent materials, reclamation method, and topsoil or topsoil substitute, used. Mine soils in Virginia that had formed in partially oxidized sandstone overburden have been recorded 
to have a surface $\mathrm{pH}$ of 5.5, and 7.5 in unoxidized sandstone and siltstone overburden (Roberts et al., 1988; Hearing et al., 1993). Thomas et al. (2000) sampled four different aged mine soils in West Virginia and found that $\mathrm{pH}$ was between 5 and 6, Hearing et al. (2004) also found similar $\mathrm{pH}$ values in mine soils in Virginia of 5.6 and 6.6. However, Ciolkosz et al. (1985) found that non-topsoiled mine soils in Pennsylvania ranging in age from 1 to 29 years since reclamation had low $\mathrm{pH}$ of at least one horizon $<4.0$. Thurman and Sencindiver (1986) also recorded strongly acid soils in West Virginia surface mines of 4.1-5.1.

Electrical conductivity (EC) is the ability of a media to transmit an electrical current (Grisso et al., 2009), which is commonly presented as a measurement of salts in a 1:1 soil water solution in decisiemens per meter $(\mathrm{dS} / \mathrm{m})$ at $25^{\circ} \mathrm{C}$. Electrical conductivity impacts soil water and soil chemical processes. Roberts et al. (1988) found soil EC to increase with carbonate content comparing sandstone and siltstone parent materials. Mine soils with sandstone material had a recorded EC of 0.13-0.14 $\mathrm{dS} \mathrm{m}^{-1}$, and soils dominated by siltstone had EC values of 0.27-0.31 $\mathrm{dS} \mathrm{m}^{-1}$. Wick et al. (2009) found EC values in reclaimed strip mine soils in Wyoming aged $<1$ year, 14 years, 26 years of $0.5,0.4$, and $0.4 \mathrm{dS} \mathrm{m}^{-1}$, respectively. Mine soils in Ohio were found to have similar EC values ranging from $0.05 \mathrm{dS} \mathrm{m}^{-1}$ to $0.33 \mathrm{dS} \mathrm{m}^{-1}$ (Shrestha and Lal, 2011).

\section{Biological Properties}

Soil organic matter (SOM) is the fraction of organic material in a soil that includes plant and animal residues, cells and tissues of soil organisms, and products synthesized by soil organisms (Brady and Weil, 2004). Soil organic matter was measured on mine soils in Pennsylvania by Pedersen et al. (1980), and found to be between 0.16-0.90\%. Bendfeldt et al. (2001) measured SOM during a 16 year study on amended mine soils with a control mine soil increasing from 
$2,000 \mathrm{~kg} \mathrm{ha}^{-1}$ to $9,000 \mathrm{~kg} \mathrm{ha}^{-1}$, and a mine soil amended with native top soil and lime increasing from $2,000 \mathrm{~kg} \mathrm{ha}^{-1}$ to $12,000 \mathrm{~kg} \mathrm{ha}^{-1}$ over the 16 year time period.

Soil respiration is a measure of biological activity through the release of carbon dioxide (CO2). Gildon and Rimmer (1993) recorded mine soil respiration at an average of $2.8 \mathrm{~cm}^{3} \mathrm{~kg}^{-1}$ $\mathrm{hr}^{-1}$. Visser et al. (1983) compared undisturbed soil and disturbed soil respiration and found that the undisturbed soil showed respiration values of $4.3 \mathrm{~cm}^{3} \mathrm{~kg}^{-1} \mathrm{hr}^{-1}$, whereas the disturbed soil respiration was significantly lower with a value of $1.6 \mathrm{~cm}^{3} \mathrm{~kg}^{-1} \mathrm{hr}^{-1}$. A study comparing amended and unamended mine soils (Stroo and Jencks, 1982) found that the amended mine soils had soil respiration of $6.4 \mathrm{~cm}^{3} \mathrm{~kg}^{-1} \mathrm{hr}^{-1}$ compared to the unamended mine soil of $0.9 \mathrm{~cm}^{3} \mathrm{~kg}^{-1}$ $\mathrm{hr}^{-1}$.

Land-use and management can alter the natural soil composition and pattern through erosion, change in soil water functions, and loss of organic matter, and therefore land-use and management can be the drivers of soil health (Kibblewhite et al. 2008) In this study, the process of mining and reclamation of mine soils affects the overall soil health by exposing unweathered bedrock which will affect the texture, $\mathrm{pH}$, and chemical processes and in turn biological properties. The regrading of topsoil or soil substitute could result in high bulk densities, low porosity, poor structure, and limited air and water movement, all affecting plant health and successful establishment.

\section{Soil Health}

The importance of and interest in soil assessment has existed for centuries, primarily as a tool to determine the soil's ability for crop production (Bunemann et al. 2018). The term soil quality was first mentioned in literature by Mausel, (1971; cited in Bunemann et al. 2018) who 
defined soil quality as "the ability of soils to yield corn, soybeans and wheat under conditions of high-level management.” Most definitions of soil quality focus on agricultural production, however Doran and Parkin (1994) wanted to stress environmental and ecosystem health issues regarding soil quality, and therefore defined it as "the capacity of a soil to function within ecosystem boundaries to sustain biological productivity, maintain environmental quality, and promote plant and animal health," animal health including human health. Doran and Safely (1997) later went on to define soil health as "the continued capacity of soil to function as a vital living system, within ecosystem and land-use boundaries, to sustain biological productivity, promote the quality of air and water environments, and maintain plant, animal, and human health." Soil health is now used to emphasize that soil is a living system.

The concept of soil health views soil as a finite and dynamic living resource, and its capacity to support agricultural services and necessary ecosystem services (Doran and Zeiss, 2000; Kibblewhite et al. 2008). Agricultural services include the production of food and fiber, and ecosystem services include water quality and supply, erosion control, atmospheric composition and climate regulation, pollutant attenuation and degradation, pest and disease control, and biodiversity conservation. These ecosystem services are dependent on four main functions that include carbon (C) transformations, nutrient cycling, soil structure maintenance, and biological population regulation (Kibblewhite et al. 2008). The health of soil determines its ability to provide nutritional and physical support for biological production and waste recycling, and to act as a filter for air and water quality (Harris et al. 1996). According to the Soil Health Institute (2019), "improving soil health boosts crop yield, enhances water quality, increases drought resilience, reduces greenhouses gas emissions, increases carbon sequestration, provides pollinator habitat, and builds disease suppression. The term soil health is used to describe the 
condition or quality of the soil as a resource based on a set of independent soil indicators including physical, chemical, and biological soil properties (Kibblewhite et al. 2007).

\section{Soil Health Indicators}

Soil health assessment does not depend on a single soil property/indicator, or a universal list of indicators, but is unique to location and sophistication of measurements made (Riley, 2001). Management goals for a given land should be identified before soil health measurement methods are chosen (Laishram et al., 2012). Physical, chemical, and biological indicators chosen to evaluate soil health should be selected based on ease of assessment, accessibility, representation of the soil, and type of data needed for assessment (qualitative/quantitative) (Kibblewhite et al. 2007). Some characteristics of the soil health indicators are to exhibit a good correlation with beneficial soil functions, to be relatively cheap and easy to measure (Parisi et al., 2005), and to be sensitive to management and climate. However, the indicators for long-term quality changes, should not be confused with short-term changes caused by seasonal weather patterns (Doran and Parkin, 1994). Physical soil health indicators include bulk density, aggregation, infiltration and water movement, and soil available water. Chemical indicators include $\mathrm{pH}$, electrical conductivity, soil nitrate and other mineral nutrients. Biological indicators include respiration, organic matter, soil microorganims, etc. (Doran and Parkin, 1996).

A minimum data set (MDS) was proposed by Larson and Pierce (1991) that included basic soil quality indicators and standard methodologies to assess soil quality. The indicators included nutrient availability, total organic $\mathrm{C}$, labile organic $\mathrm{C}$, particle size, plant-available water capacity, soil structure, soil strength, maximum rooting depth, $\mathrm{pH}$, and electrical conductivity (EC). Doran and Parkin (1994) also proposed a list of basic physical, chemical, and biological characteristics that included texture, soil bulk density, infiltration, and respiration. 
Bunemann et al. (2018) summarized and evaluated forty-five datasets from sixty-two publications and identified the most frequently used soil quality indicators. Total organic matter/carbon and $\mathrm{pH}$ were the most proposed indicators, followed by available phosphorous, water storage, and bulk density, and texture, available potassium and total nitrogen. It was also found that biological indicators, such as respiration, were left out of $40 \%$ of the reviewed datasets. Mentioning of climate, management, specific site characteristics, plant yield and nutrient status were rarely or often not included in the datasets.

Kibblewhite et al. (2008) describes soil as a "multicomponent and multifunctional system with definable operating limits." Therefore, critical limits or threshold values of soil health indicators must also be established to monitor changes in soil health (Arshad and Martin, 2002). To maintain normal or productive soil functions, the indicators should be within specific threshold values. Minimum and maximum limits for each soil indicator and its role in vital functions should be understood in order to prevent degradation and support soil improvement and guide management.

\section{Physical Indicators}

Soil texture is one of the most influential physical soil properties, and is comprised of sand, silt, and clay particles. Texture is divided into twelve textural classes, which describe the percentages of sand, silt, and clay (Brady and Weil, 2004). The distribution of these particles play an important role in the soil's structure, bulk density, water and air movement, $\mathrm{pH}, \mathrm{EC}$, and nutrient availability.

Aggregation affects soil structure, pore space, air and water movement, and erosion. Biological activity within the soil, such as microorganisms producing extracellular compounds that act as adhesives, can increase aggregation and therefore increase the soil structure and 
stability (Kibblewhite et al. 2008). Slaking is the process of soil aggregates disintegrating when exposed to rapid water uptake (Chan and Mullins, 1994). Unstable aggregates will break apart, lose structure, and could result in the formation of soil crusts which limit water and air movement through the soil and plant growth (USDA, 1999).

Doran and Parkin (1994) stated that "the inclusion of bulk density in a set of basic indicators is critical to proper interpretation of the importance of change in magnitude in other chemical and biochemical soil components." Bulk density varies with management, depth of sampling, and time of year (Doran and Parkin, 1994). Soils with high bulk densities can limit air and water movement, and result in restricted root growth (USDA, 1999). Ideal bulk densities for root growth vary with soil texture, ranging from $<1.6 \mathrm{~g} / \mathrm{cm}^{3}$ for sands, loamy sands to $<1.10 \mathrm{~g} / \mathrm{cm}^{3}$ for clay soils with $>45 \%$ clay. Restricting bulk densities for sands, loamy sands are $>1.80 \mathrm{~g} / \mathrm{cm}^{3}$ and $>1.47 \mathrm{~g} / \mathrm{cm}^{3}$ for clays. Abu-hamdeh (2003) found that crop yields were affected by wheel traffic. Yields were reduced by $26.8 \%$ and $14.5 \%$ in 2000 and 2001. Two years after compaction, bulk density was 1.6 to $6.1 \%$ greater than no compaction. Plants in the compacted plots also had greater root density near the base of the plant, and lower plant height.

Infiltration rate is the rate at which water enters the soil and is dependent on soil texture and aggregation (structure and pore space), macropores caused by soil organisms, and soil organic matter. Infiltration rate is important when determining water movement throughout a soil and water holding capacity (USDA, 1999). High compaction of soils results in an increase of bulk density, decrease of porosity, and can limit infiltration rates (Gregory et al., 2006). Steady infiltration rates vary with soil texture: sands: $>0.8$ inches per hour, sandy and silty soils: $0.4-$ $0.8 \mathrm{in} \mathrm{hr}^{-1}$, loams: $0.2-0.4 \mathrm{in} \mathrm{hr}^{-1}$, clayey soils: $0.04-0.2 \mathrm{in} \mathrm{hr}^{-1}$, and sodic clayey soils: $<0.04$ in $\mathrm{hr}^{-1}$ (Hillel, 1982). Infiltration rates can also be associated with infiltration classes ranging from 
very rapid at $>20 \mathrm{in} / \mathrm{hr}$ to very slow at 0.0015 to $0.06 \mathrm{in} \mathrm{hr}^{-1}$, and impermeable at $<0.0015 \mathrm{in} \mathrm{hr}^{-1}$ (USDA, 1999).

\section{Chemical Indicators}

Soil $\mathrm{pH}$ is important when determining soil fertility and productivity. Suitable $\mathrm{pH}$ levels generally fall between 6.0 and 7.5 for general crop production, however ideal $\mathrm{pH}$ ranges are crop specific (Whittaker et al., 1959). Soil $\mathrm{pH}$ levels that are not within range for a specific plant or crop, can lead to a decrease in available nutrients, microbial activity, plant biomass, and overall soil health (USDA-NRCS). A soil pH of 6.5 is considered optimum for nutrient availability, while a lower $\mathrm{pH}$ increases the solubility of potentially toxic nutrients (Al, $\mathrm{Mn}$, and $\mathrm{Fe}$ ) and decreases the availability of macronutrients and secondary nutrients $(\mathrm{N}, \mathrm{P}, \mathrm{K}, \mathrm{S}, \mathrm{Ca}, \mathrm{Mg})$.

Whereas high $\mathrm{pH}$ decreases the availability of micronutrients $(\mathrm{B}, \mathrm{Cu}, \mathrm{Fe}, \mathrm{Cl}, \mathrm{Mn}, \mathrm{Mo}$, and Zn) (Cornell University, 2010). Soil pH can also impact microbial communities and activities, such as $\mathrm{C}$ and $\mathrm{N}$ cycling. Curtin et al. (1998) found that an increase in $\mathrm{pH}$ of slightly acid soils resulted in the stimulation and increase of $\mathrm{C}$ and $\mathrm{N}$ mineralization by $37-67 \%$.

Soil EC also affects soil fertility along with crop yields and quality, nutrient availability and microorganism activity. EC values that range from 0 and $0.8 \mathrm{dS} / \mathrm{m}$ are considered acceptable for general crop production, however ideal EC values are plant and site specific. Salinity classes for EC values range from non-saline at $0-0.98 \mathrm{dS} / \mathrm{m}$ to strongly saline at $>6.07 \mathrm{dS} / \mathrm{m}$ (Soil Survey Staff, 1993; Janzen, 1993; Smith and Doran, 1993). Salts are naturally found in soils due to its mineralogy or diminished weathered mineral bound salt leaching. Increase salt concentrations at the soil surface $(>4.0 \mathrm{dS} / \mathrm{m}$ in saturation extract) will affect the biological water availability in a soil and can result in limited plant growth on sensitive species (USDA, 1999). 


\section{Biological Indicators}

Soil respiration, or release of carbon dioxide (CO2) from the activity of roots, micro- and macro-organisms in the soil, is a direct reflection of biological activity in the soil and is a positive attribute for soil health (USDA, 1999). Respiration reflects the degradation of plant residues, root exudates, soil organic matter (SOM), soil organic carbon (SOC), and micro- and macro-organisms, which indicate loss of SOC, nutrient cycling, and response to management (Parkin et al., 1996). Higher soil respiration measurements indicate more biological activity and SOM present, which reflects the capacity to supply and sustain biological productivity. However, respiration measurements are affected by soil temperature and moisture. Low measurements of respiration may indicate reduced aerobic microbial activity in the soil, low organic matter, limiting temperature and moisture, or anaerobic conditions. Low soil respiration may result in a decrease in plant available nutrients, resulting in poor plant growth, and anaerobic conditions can lead to denitrification and sulfur volatilization (SQEH, 2011).

Microorganisms decompose organic matter, promote soil structure, fix nitrogen, consume greenhouse gases, and help to recycle and supply beneficial nutrients to plants (SARE, 2012; Parkin et al., 1996). Macro-organisms, including arthropods and earthworms, also aid in organic matter breakdown and movement, and contribute to soil structure, water and air movement, and nutrient cycling (Moldenke, 2001; Edwards, 2001). A range of 16.8-33.6 lbs CO2-C/acre/day reflects ideal soil biological activity with adequate organic matter (Woods End Research, 1997). The breakdown of plant litter by the micro- and macro-organisms contribute to the amount of organic matter present in the soil which aids in other soil functions.

Lehman et al. (2015) states that SOM, is one of the "single most important soil quality indicators for nearly all soils throughout the world." The amount of SOM darkens soil color, 
provides food and nutrients for soil biology, and positively influences aggregation and granulation, which in turns increases water holding capacity and infiltration rate. Soil organic matter also has a positive effect on soil chemical properties such as cation exchange and soil $\mathrm{pH}$ buffering capacity. According to Cornell University Cooperative Extension (2008), most productive agricultural soils have SOM of 3 to $6 \%$.

\section{Vegetation as a Soil Health Indicator}

Another possible soil health indicator that has been discussed by the Soil Health Institute is vegetation diversity and/or biomass production (Personal communication Dr. Eugenia M. PenaYewtukhiw, March 2019). Measurement and classification of vegetation could serve as an alternate indicator of soil health, which could reduce time and cost of sampling other biological soil indicators (Laishram et al., 2012). Hilgard (1914) used natural vegetation growing on the land as an indicator of soil productivity and value, however thorough physical and chemical evaluations were needed to make conclusions.

A study by Gillison et al. (2003) comparing vegetation and soil macroinvertebrates found positive correlations between termite species richness and canopy height, plant basal area, and plant richness. Tree biomass and canopy cover have also been significantly correlated to soil quality index values (Mukhopadhyay et al., 2016). Zak et al. (2003) found that an increase in plant diversity and biomass increased and modified microbial communities. Plant diversity also enhanced microbial processes such as nutrient cycling. Soil carbon storage has been found to increase with plant and microbial diversity (Lange et al., 2015).

Pohl et al. (2009) found that aggregate stability showed a slight positive correlation with the number of plant species $\left(R^{2}=0.36\right)$ and root density $\left(R^{2}=0.23\right)$ in a study of plant diversity and cover on soil stability. In a study looking at changes in soil aggregation and prairie restoration, 
Jastrow (1987) found that the percentage of water-stable macroaggregates $(>0.2 \mathrm{~mm})$ increased with time since cultivation, and had the least water-stable aggregates in continuous corn compared to prairie. Percentage of macroaggregates and biomass of roots and rhizomes was strongly correlated with an $\mathrm{R}^{2}=0.82$. Total live aboveground biomass decreased between the second and fifth growing season, and increased after the fifth growing season with time since cultivation. An increase in plant diversity, biomass, and root systems could be an indicator of increased soil stability, microbial communities and nutrient cycling, and adequate water and air movement in a soil. Measuring and compiling the values of these soil health indicators can give a general overview of soil health and its functions.

A study in mine soils by Roberts et al. (1988) compared biomass production of tall fescue and parent material of sandstone and siltstone over a 3 year period. Overall biomass production was found to be higher in the sandstone parent material, and decreased in siltstone materials. In the second year, biomass was highest in a sandstone to siltstone ratio of $2: 1$ at $9.30 \mathrm{Mg} \mathrm{ha}^{-1}$.

Biomass was found to be 6.5 and $6.4 \mathrm{Mg} \mathrm{ha}^{-1}$ in pure sandstone and 1:2 sandstone to siltstone, respectively.

\section{Assessing Soil Health: Methods}

Determining how healthy soils has been a difficult task due to the low amount of globally accepted soil health measurements and methods. However, the Soil Health Institute (2019) has established, and continues to work on, a recommended list (Table 1) of soil health indicators that landowners, farmers, and scientists can use around the world. This list, referred to as "Tier 1" measures, includes nineteen indicators such as organic carbon, $\mathrm{pH}$, water-stable aggregation, crop yield, texture, EC, nutrient availability, bulk density, and infiltration rate. Tier 1 measures 
have known threshold values and are defined regionally to improve management strategies for increased soil function. Other possible soil health indicators, such as biological indicators, are defined as Tier 2 or Tier 3 . These measurements need more research in their interpretation, threshold values, and management recommendations to be included in the Tier 1 measurements. The methods adopted by the Soil Health Institute to measure Tier 1 indicators are in the table below.

Soil health evaluation frameworks are also being assessed. The Soil Health Management Assessment Framework (Andrews et al., 2010) proposes a framework that assesses impacts of soil management on soil functions in various climates, soil types, and management systems. The framework is divided into three steps that include indicator selection, indicator interpretation, and integration into an index. The Cornell Comprehensive Assessment of Soil Health (CASH) (Moebius-Clune et al., 2016) uses the integration of soil health measurements as its core focus. This framework selects a set of indicators and compiles them into a user-friendly report with scores, constraints, and management suggestions. 
Table 1. Tier 1 Soil Health Indicators and Methods to be Assessed (updated 10/8/2018)

\begin{tabular}{|c|c|c|}
\hline Indicator & Method & Reference \\
\hline Soil pH & 1:2 soil:water, standard $\mathrm{pH}$ electrode system & Thomas, 1996 \\
\hline \begin{tabular}{|l|} 
Soil Electrical \\
Conductivity (EC)
\end{tabular} & $\begin{array}{l}\text { 1:2 soil:water, standard electrical conductivity meter } \\
\text { system }\end{array}$ & Rhoades, 1996 \\
\hline $\begin{array}{l}\text { Cation Exchange Capacity } \\
\text { (CEC) }\end{array}$ & $\begin{array}{l}\text { Sum of Cations: } \\
\text { For soil } \mathrm{pH} \geq 7.2 \text { : use ammonium acetate extractant; } \\
\text { For soil } \mathrm{pH}<7.2 \text { : use Mehlich } 3 \text { extractant }\end{array}$ & $\begin{array}{l}\text { Knudsen, et al., 1982; Sikora } \\
\text { and Moore, } 2014\end{array}$ \\
\hline$\%$ Base Saturation (BS) & $\begin{array}{l}\text { Calculation: } \\
\text { For soil } \mathrm{pH} \geq 7.2 \text { : use ammonium acetate extractant; } \\
\text { For soil } \mathrm{pH}<7.2 \text { : use Mehlich } 3 \text { extractant }\end{array}$ & $\begin{array}{l}\text { Knudsen, et al., 1982; Sikora } \\
\text { and Moore, } 2014\end{array}$ \\
\hline Extractable P & $\begin{array}{l}\text { For soil } \mathrm{pH} \geq 7.2 \text { : use sodium bicarbonate extractant; } \\
\text { For soil } \mathrm{pH}<7.2 \text { : use Mehlich } 3 \text { extractant }\end{array}$ & $\begin{array}{l}\text { Olsen and Sommers, 1982; } \\
\text { Sikora and Moore, } 2014\end{array}$ \\
\hline Extractable $\mathrm{K}, \mathrm{Ca}, \mathrm{Mg}, \mathrm{Na}$ & $\begin{array}{l}\text { For soil } \mathrm{pH} \geq 7.2 \text { : use ammonium acetate extractant; } \\
\text { For soil } \mathrm{pH}<7.2 \text { : use Mehlich } 3 \text { extractant }\end{array}$ & $\begin{array}{l}\text { Knudsen, et al., 1982; Sikora } \\
\text { and Moore, } 2014\end{array}$ \\
\hline $\begin{array}{l}\text { Extractable } \mathrm{Fe}, \mathrm{Zn}, \mathrm{Cu}, \\
\text { Mn }\end{array}$ & $\begin{array}{l}\text { For soil } \mathrm{pH} \geq 7.2 \text { : use DTPA extractant derivatives; } \\
\text { For soil } \mathrm{pH}<7.2 \text { : use Mehlich } 3 \text { extractant }\end{array}$ & $\begin{array}{l}\text { Sikora and Moore, 2014; } \\
\text { Lindsay and Norvell, } 1978\end{array}$ \\
\hline Total Nitrogen & Dry combustion & Nelson and Sommers, 1996 \\
\hline $\begin{array}{l}\text { Soil Organic Carbon } \\
\text { (SOC) }\end{array}$ & $\begin{array}{l}\text { Dry combustion, corrected for Inorganic C, if present, } \\
\text { using pressure- calcimeter }\end{array}$ & $\begin{array}{l}\text { Nelson and Sommers, 1996; } \\
\text { Sherrod, et al., } 2002\end{array}$ \\
\hline Soil Texture & $\begin{array}{l}\text { Pipette Method with a minimum of } 3 \text { size classes. } \\
\text { Weight/volume measurements }\end{array}$ & Gee and Bauder, 1986 \\
\hline Aggregate Stability & Wet sieve procedure. Weight measurement & Kemper and Roseneau, 1986 \\
\hline $\begin{array}{l}\text { Available Water Holding } \\
\text { Capacity }\end{array}$ & $\begin{array}{l}\text { Ceramic plate method measured at }-33 \mathrm{kPa}(-10 \mathrm{kPa} \\
\text { for sandy soils) and }-1500 \mathrm{kPa}\end{array}$ & Klute, 1986 \\
\hline Bulk Density (BD) & $\begin{array}{l}\text { Core method: diameter to be determined, (most likely } \\
\text { 2-inch or } 5.08 \mathrm{~cm} \text { ) }\end{array}$ & Blake and Hartge, 1986 \\
\hline Erosion Rating & $\begin{array}{l}\text { USDA model(s) (RUSLE2, WEPP, WEPS) } \\
\text { appropriate for site }\end{array}$ & $\begin{array}{l}\text { USDA Agricultural Research } \\
\text { Service }\end{array}$ \\
\hline \begin{tabular}{|l|} 
Soil Penetration \\
Resistance \\
\end{tabular} & Commercial soil penetrometer & Lowery and Morrison, 2002 \\
\hline $\begin{array}{l}\text { Saturated Hydraulic } \\
\text { Conductivity }\end{array}$ & SATURO dual head infiltrometer & Reynolds, et al., 2012 \\
\hline Crop Yield & $\begin{array}{l}\text { Obtained from historical and current plot yield data } \\
\text { provided by site manager }\end{array}$ & \\
\hline \begin{tabular}{|l|} 
Short-Term Carbon \\
Mineralization \\
\end{tabular} & $\begin{array}{l}\text { 4-day incubation followed by } \mathrm{CO}_{2}-\mathrm{C} \text { evolution and } \\
\text { capture at } 50 \% \text { water-filled pore space. }\end{array}$ & Zibilske, 1994 \\
\hline $\begin{array}{l}\text { Nitrogen Mineralization } \\
\text { Rate }\end{array}$ & $\begin{array}{l}\text { Short-term anaerobic incubation with ammonium and } \\
\text { nitrate measured colorimetrically pre- and post- } \\
\text { incubation }\end{array}$ & Bundy and Meisinger, 1994 \\
\hline
\end{tabular}




\section{Study Experiments' Objectives and Hypotheses}

\section{Experiment I: Soil health indicator characterization using the NRCS Soil Quality Test Kit}

and standard research laboratory measurements.

\section{Objectives:}

i. Evaluate the effectiveness of the NRCS Soil Quality Test Kit to standard field and laboratory methods in assessing soil health in reclaimed mine sites.

ii. Assess and compare soil health indicators between reclaimed mine sites using the NRCS Soil Quality Test Kit.

\section{Hypotheses:}

i. The results of the NRCS Soil Quality Test Kit methods will be representative of those measured with standard field and laboratory methods.

ii. Soil health indicator measurements made with the NRCS Soil Quality Test Kit will be sensitive enough to detect differences in soil health due to time since reclamation.

As mine soils begin to develop after reclamation activities finish, soil health indicators will change and improve with time. Improvement will be considered by a decrease in bulk density and electrical conductivity, and an increase in dry aggregation, wet aggregation, infiltration, $\mathrm{pH}$, nitrate, and respiration. The NRCS Soil Quality Test Kit will be able to detect these changes with time since reclamation.

\section{Experiment II: Soil health analysis based on plant indicators.}

\section{Objective:}

i. Determine soil health and vegetation properties using standard field and laboratory methods 


\section{Hypotheses:}

i. Soil health indicators will improve with time since reclamation due to natural soil processes and development over time.

ii. Plant diversity will increase with time since reclamation as a result of improved soil health indicators.

\section{Experiment III: Soil health response to fertilization management practices.}

\section{Objective:}

i. Determine biomass changes with management (urea fertilization) on three different mine sites through soil health indicators and vegetation measurements.

\section{Hypothesis:}

i. Soil health indicators and aboveground biomass and diversity/speciation will be an indicator of soil health and show different responses between the younger and older sites with the application of urea management. 


\section{CHAPTER 3. MATERIALS AND METHODS}

\section{Site Description}

Four reclaimed mine sites varying in age located in Monongalia County, WV were selected to evaluate soil health based on time since reclamation. Monongalia Co. is located in the Appalachian Highlands physiographic division (Fig. 1). Elevation ranges from 293m to $640 \mathrm{~m}$. The mean annual temperature is $11^{\circ} \mathrm{C}$, with average annual rainfall of $104.6 \mathrm{~cm}$, and average annual snowfall ranging from $76.2-114.3 \mathrm{~cm}$ depending on elevation (Childs, 2015). West Virginia had record breaking rainfall in 2018. Rainfall in Morgantown, WV for 2018 (Table 2) was $31.4 \mathrm{~cm}$ above average and $18.7 \mathrm{~cm}$ above 2017.

Table 2. Average annual rainfall in Morgantown, WV for 2017 and 2018 (data taken from U.S. Climate Data, 2019).

\begin{tabular}{|c|c|c|}
\hline & 2017 & 2018 \\
\hline & \multicolumn{2}{|c|}{$\mathrm{cm}$} \\
\hline Jan. & 8.8 & 7.0 \\
\hline Feb. & 3.8 & 17.0 \\
\hline Mar. & 10.5 & 7.7 \\
\hline Apr. & 17.3 & 16.7 \\
\hline May & 11.6 & 15.0 \\
\hline June & 11.6 & 13.0 \\
\hline July & 22.6 & 9.1 \\
\hline Aug. & 3.3 & 12.6 \\
\hline Sept. & 2.3 & 18.6 \\
\hline Oct. & 10.1 & 4.7 \\
\hline Nov. & 8.1 & 7.9 \\
\hline Dec. & 7.3 & 6.7 \\
\hline Total & 117.3 & 136.0 \\
\hline
\end{tabular}

The four sites vary in age from 2 to 32 years since reclamation. All mine sites were owned, mined and reclaimed by Patriot Mining Company. Schafer mine site (Fig. 2), referred to as $\mathrm{WV} 2$, located at $39^{\circ} 39^{\prime} 3.9^{\prime \prime} \mathrm{N}, 80^{\circ} 03^{\prime} 24^{\prime \prime} \mathrm{W}$ was reclaimed in 2015 and was 2 years old at the beginning of this research in 2017. Site WV2 was approximately 0.73 
ha $(1.8 \mathrm{ac})$ and described prior to mining as a Westmoreland silt loam according to Web Soil Survey (2018). New Hill mine site 11 (Fig. 3), referred to a WV11, located at 39 40' 23 ” N, $80^{\circ} 03$ ' 16.9” W was reclaimed in 2006 and was 11 years old. Site WV11 was approximately 0.53 ha (1.3 ac) and described prior to mining as Dormont and Guernsey silt loams, Fairpoint silt loam, and Itmann very channery loam. Metz mine site 16 (Fig. 4), referred to as WV16, located at $39^{\circ} 38^{\prime} 50^{\prime \prime} \mathrm{N}, 80^{\circ} 01^{\prime} 30^{\prime \prime} \mathrm{W}$ was reclaimed in 2001 and was 16 years old. Site WV16 was approximately 1.17 ha (2.9 ac) and described prior to mining as Bethesda loam. Mylan mine site 32 (Fig. 5), referred to as WV32, located at $39^{\circ}$ $38^{\prime} 26^{\prime \prime} \mathrm{N}, 80^{\circ} 01^{\prime} 60^{\prime}$ 'W was reclaimed in 1985, and was 32 years old. Site WV32 was approximately 0.93 ha $(2.3 \mathrm{ac})$ and was also described prior to mining as Bethesda loam. These sites were all mined for Waynesburg coal using contour mining. Overburden material consisted of $70-80 \%$ sandstone, with the remaining percentage being shale. The reclamation methods were within the guidelines of SMCRA, and included backfilling, an addition of 15 to $20 \mathrm{~cm}$ of native topsoil, and grading to original contour. The sites were then seeded to mixed grass-legume pastures which predominately included orchardgrass (Dactylis glomerata), timothy (Phleum pretense L.), tall fescue (Festuca arundinacea), red clover (Trifolium pretense), white clover (Trifolium repens), and birdsfoot trefoil (Lotus corniculatus). 


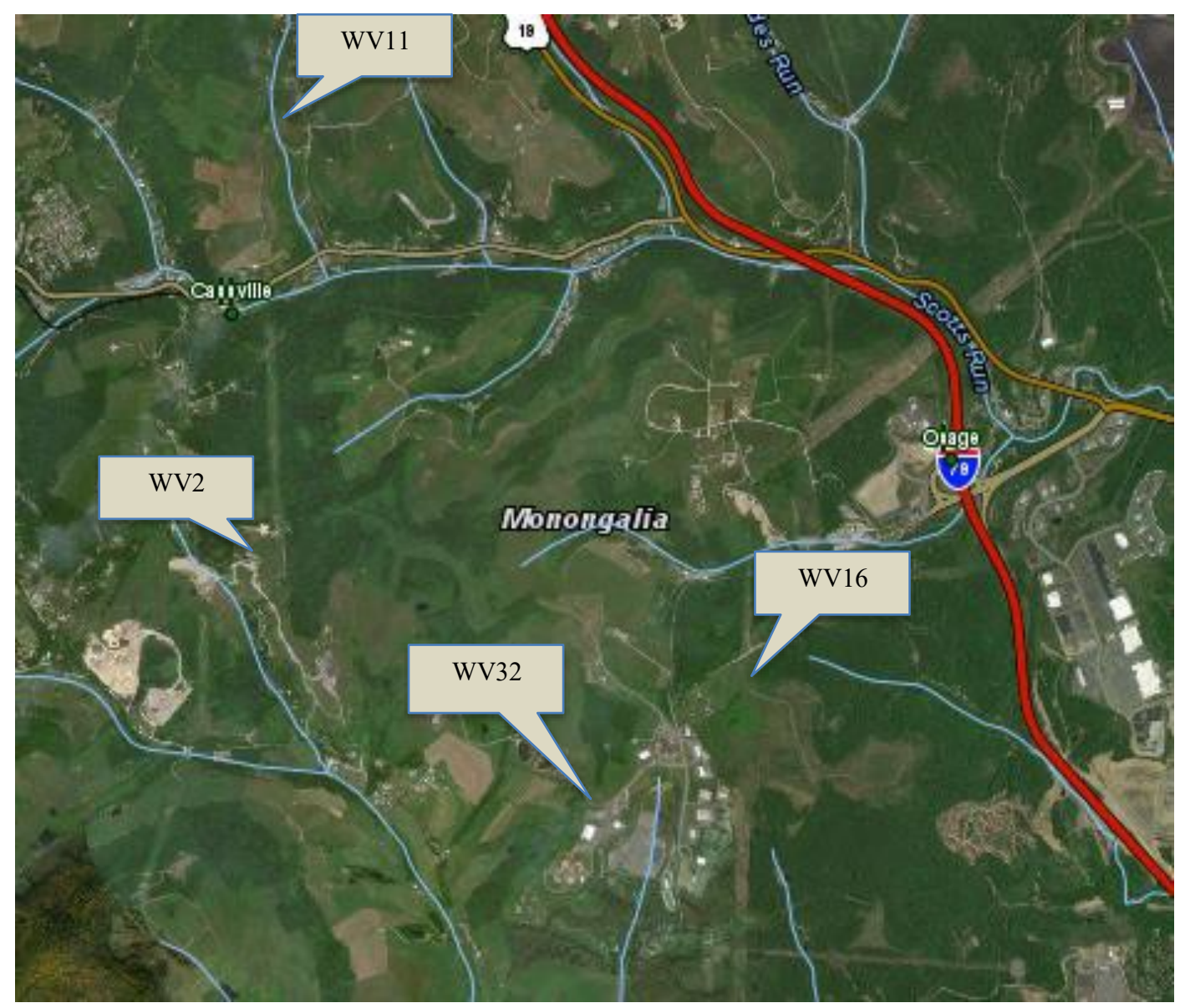

Figure 1. Satellite view of the study sites located in Monongalia County: WV2, WV11, WV16, and WV32.

\section{Experiment Description}

\section{Soil Sampling}

\section{Experiment I:}

Seven soil health indicators were measured using the NRCS Soil Quality Test Kit at all four sites (WV2, WV11, WV16, WV32) between May and September of 2018. After placing fifty (50) geographically positioned (GPS) soil sampling points in each site using a sub-meter GPS unit, ten (10) sample points were selected to be evaluated by the NRCS Soil Quality Test Kit. At each selected sampling point, and as described by the USDA-NRCS Soil Quality Test Kit Guide 
protocol (2001), soil was collected from the upper $7.5 \mathrm{~cm}$ and used to measure the following soil health indicators: bulk density (BD), water infiltration (INFIL), aggregate stability (wet aggregation (WA), slaking (SL)), $\mathrm{pH}$, electrical conductivity (EC), and soil respiration (RESP. Field measured indicators included infiltration and respiration using a single metal ring. Bulk density samples were collected in an intact core with a known volume to a depth of $7.5 \mathrm{~cm}$, and were brought back to the lab to be air-dried. The same core was used to measure aggregate stability, pH, and EC between May and December 2018.

Following agricultural soil sampling protocols (sampling depth $0-15 \mathrm{~cm}$ ), the same soil health indicators were measured using standard research laboratory methods (described in Experiment II). The results from both methods were compared to evaluate, and validate the performance of the NRCS Soil Quality Test Kit.

In addition, one soil pit per site was excavated for pedologic soil profile descriptions at each mine site (Appendix A, Fig. A1 - Fig. A4).

\section{Experiment II:}

To perform this experiment, soil samples were collected on three of the four selected reclaimed mine sites, WV2, WV11 and WV16. A total of fifty (50) GPS points mentioned in Experiment I were marked in the field between May-September of 2017 and 2018. At each point, bulk samples were taken to a depth of $15 \mathrm{~cm}$ (details provided in the standard method section). From these intact samples, BD, dry aggregation (DA), and WA were measured.

Samples were then oven-dried, crushed and sieved to $<2 \mathrm{~mm}$ to analyze texture, $\mathrm{pH}$, bioavailable nutrients, and soil organic matter (SOM).

Mine site WV32 was excluded due to high slope (minimum average of $25 \%$ ) which would rate the site as non-agricultural, and exclude from further soil health analysis for agricultural use. 


\section{Experiment III:}

The experimental design was a completely randomized block (repetitions) design with three factors. The factors used were time since reclamation, fertilizer treatment (urea application rates) and three blocks. Three (3) levels of time since reclamation $2 \mathrm{yr}$ (WV2), $11 \mathrm{yr}$ (WV11) and $16 \mathrm{yr}$ (WV16), with two (2) levels of fertilizer management with and without $46.04 \mathrm{~kg} \mathrm{~N} \mathrm{ha}^{-1}$ (501b N) application were organized in three blocks (three measurements within each block and treatment). Three $6 \mathrm{~m} \times 12 \mathrm{~m}$ blocks were placed on each site. Two $6 \mathrm{~m} \times 6 \mathrm{~m}$ plots within each block were used for control (no urea application) and fertilizer treatment. To avoid a border effect, the three sample replications were located within the central $25 \mathrm{~m}^{2}$ of each plot. Therefore, three replication soil samples were collected from the control and treatment plots of each block, with a total of 6 samples per block and 18 samples per site.

Initial soil sampling, to be used as a baseline, was completed prior to urea application at each site. Urea $(46 \% \mathrm{~N})$ was applied at a rate of $46.04 \mathrm{~kg} \mathrm{~N} \mathrm{ha}^{-1}$ once in late June of 2017 and 2018. The selection of the $\mathrm{N}$ application rate was based on two experimental requirements: a) is the most commonly applied $\mathrm{N}$ rate producing yield response on most crops (Dr. J. Grove, personal communication); and b) rate should not to produce changes in soil chemical properties such as $\mathrm{pH}$ to avoid confounded effects when vegetation response (biomass and diversity) (Kidd et al., 2017).

Soil samples were collected in June 2017 and 2018 before the first and second urea application respectively. Samples were collected from the three points (three measurements) within each block and treatment for each site: WV2, WV11, and WV16. Bulk samples were taken to a depth of $15 \mathrm{~cm}$, with a $15 \mathrm{~cm}$ width. From these bulk samples, BD, DA, and WA were measured after being air dried. Samples were then oven-dried, crushed and sieved to $<2 \mathrm{~mm}$ to 
analyze texture, $\mathrm{pH}$, bioavailable nutrients, and $\mathrm{SOM}$.

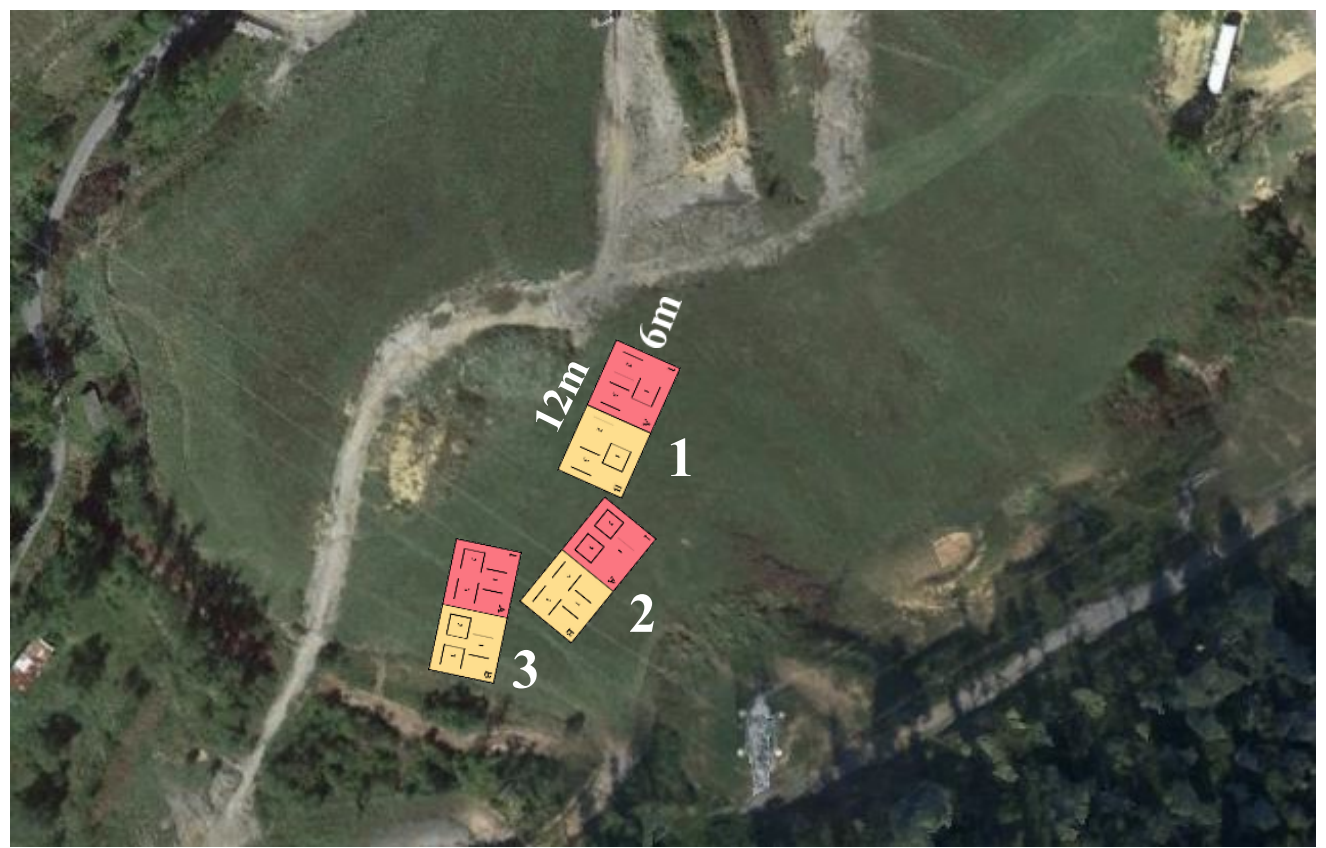

Figure 2. Satellite image of reclaimed WV2 mine site with Experiment III block locations. Red indicates plots fertilized with urea application. Yellow indicates control plots.

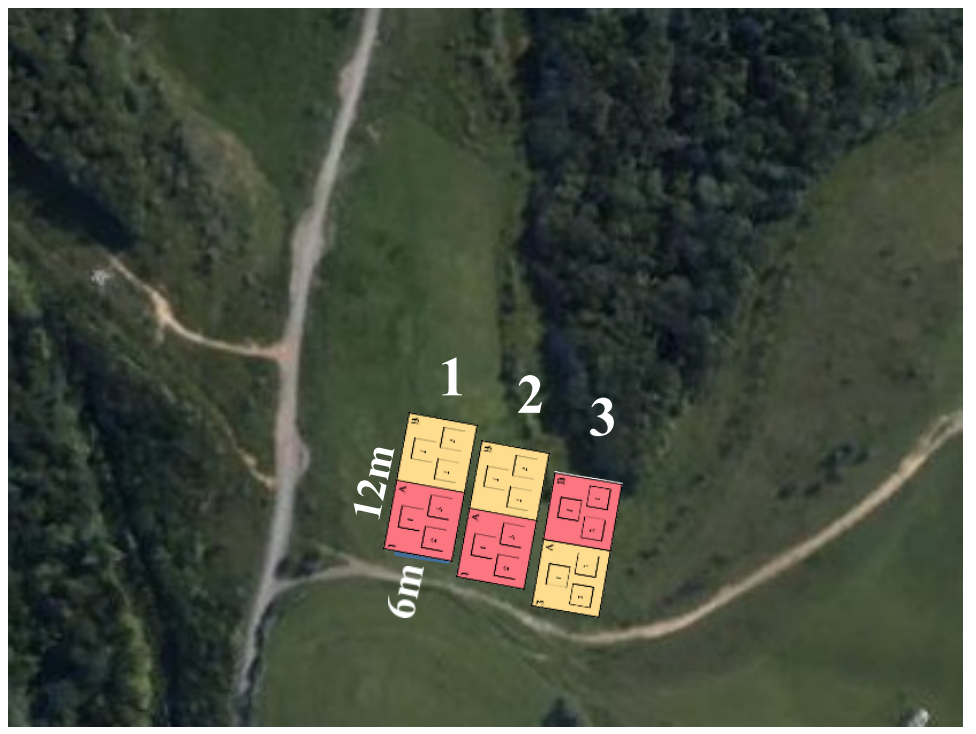

Figure 3. Satellite image of WV11 reclaimed mine site with Experiment III block locations. Red plots were fertilized with urea application. Yellow were control plots. 


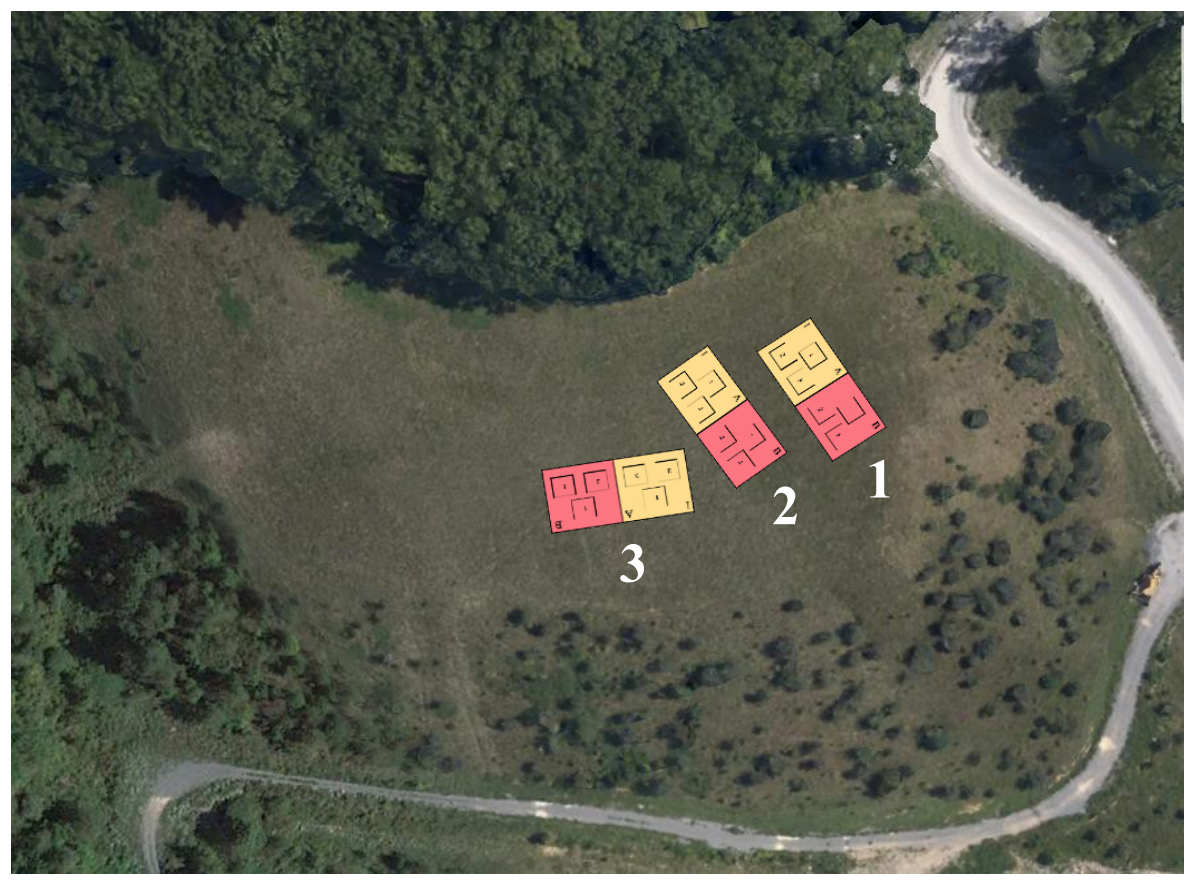

Figure 4. Satellite image of WV16 reclaimed mine site with Experiment III block locations. Red indicates plots fertilized with urea application. Yellow indicates control plots.

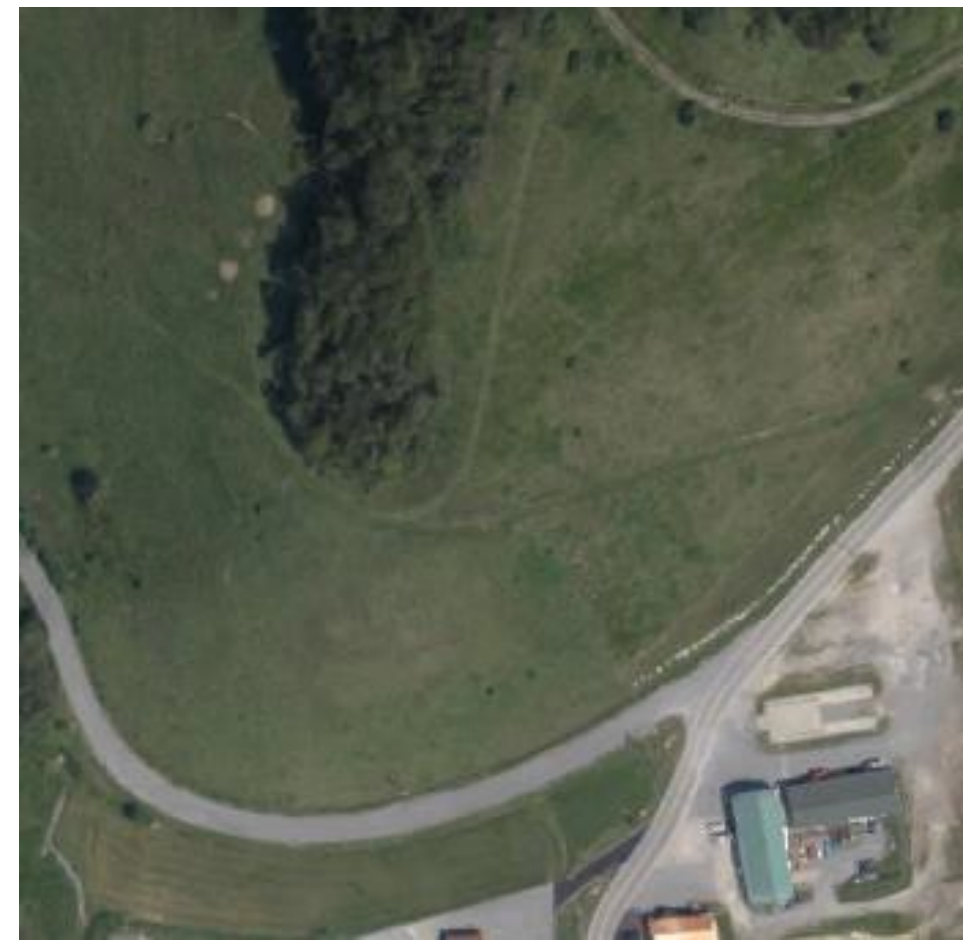

Figure 5. Satellite image of reclaimed WV32 mine site used in Experiment I. 


\section{Standard Research Methods}

The standard methods were used in Experiments I, II, and III to measure the physical, chemical and biological soil health indicators described in the next section.

\section{Physical Properties}

\section{Bulk Density:}

Bulk soil samples were taken using the excavation method (Page-Dumroese et al. 1999) at a depth of $15 \mathrm{~cm}$ and a diameter of $15 \mathrm{~cm}$. The volume of the sample was measured by using a thin plastic to line the hole, and a volume of calibrated sand was used to fill the hole. Samples were kept intact and transported to the lab to dry. Once dry, the sample was weighed to measure total weight. The sample was then used to extract an inner, uncompromised sample to be used for DA and WA. Coarse fragments $>9.5 \mathrm{~mm}$ were sieved and weighed, and the weight was subtracted from the total weight for a "corrected" bulk density using Equation 1:

$$
\rho=\frac{\text { (Total soil dry weight }- \text { coarse fragment weight })}{\text { volume of sample }\left(\mathrm{cm}^{3}\right)}
$$

\section{Saturated Hydraulic Conductivity:}

A Wooding infiltrometer (Wooding, 1968) was used to measure surface saturated hydraulic conductivity using Equation 2:

$$
K s=\frac{i f-4 b S^{2}}{(\pi R s(T f-T i)}
$$

\section{Aggregate Stability:}

Aggregate stability was measured using the extracted, uncompromised core from the dry 
bulk sample. The core was weighed and placed in a paper bag. Mean weight diameter (MWD) was used as an index to quantify aggregate stability and was calculated using Equation 3.

Dry aggregate stability: The drop-shatter method (Diaz-Zorita et al., 2002) was used to break the sample. The sample was then shaken at an amplitude of $2 \mathrm{~mm}$ for 30 seconds in a Fritsch Analysette 3 shaker using 16mm, 8mm, 4mm, 2mm, 1mm, and 0.5mm sieves.

Wet aggregate stability: Twenty grams of the $4-8 \mathrm{~mm}$ aggregates separated from the dry aggregate stability method were weighed and used for wet-sieving using the Yoder method (Yoder, 1936) for five minutes.

$$
M W D=\sum_{i=1}^{n} \overline{x l} w i
$$

where $\overline{x i}$ is the mean dimeter of each size fraction. wi is the proportion of the total sample weight occurring in the size fraction $\mathrm{i}$.

\section{Soil Texture:}

Soil texture was measured using the pipette method (Dane and Topp, 2002). Approximately (10) grams of soil remaining from the bulk density was weighed, titrated with $35 \%$ hydrogen peroxide, and dispersed using sodium hexametaphosphate and physical shaking/stirring. Based on the temperature of the room, after settling for the appropriate time (temperature defined) a 25 $\mathrm{mL}$ aliquot was taken at a $5 \mathrm{~cm}$ depth to determine clay contend, and the sand fraction was determined by sieving the whole sample with a $53 \mu \mathrm{m}$, sieve.

\section{Chemical Properties.}

\section{Soil Bioavailable Nutrients:}

The remaining bulk sample was crushed and sieved to $<2 \mathrm{~mm}$. Bioavailable nutrients 
including: $\mathrm{Mg}, \mathrm{Ca}, \mathrm{K}, \mathrm{Na}, \mathrm{P}, \mathrm{B}, \mathrm{Zn}, \mathrm{Fe}$, and Al were measured using a Mehlich III extraction with a 10:1 solution (Mehlich, 1984). These nutrients were chosen to determine amounts of plant-available nutrients necessary for plant growth, and to determine amounts of possible toxic heavy metals due to mining.

\section{Soil pH and EC:}

Soil pH (bench meter - Beckman 43) and EC (bench meter - Mettler Toledo S230 SevenCompact) were measured using a 1:1 soil water solution using $10 \mathrm{~g}$ of $<2 \mathrm{~mm}$ soil (Sparks, 1996).

\section{Biological Properties.}

\section{Soil Respiration:}

A Solvita test was conducted to measure soil respiration using a $\mathrm{CO}_{2}$ burst (Haney et al. 2008). Soil samples were sieved and weighed to $40 \pm 1 \mathrm{~g}$. Based on the bulk density of the sample, a given amount of water was determined, and a Solvita gel paddle was inserted into a glass jar with the soil sample and left for $24 \mathrm{hrs}$.

\section{Soil Organic Matter Content:}

Soil organic matter was measured using loss on ignition (Heiri et al. 2001).

\section{NRCS Soil Quality Test Kit Methods}

The NRCS Soil Quality Test Kit methods were used only in Experiment I to measure the below specified physical, chemical and biological soil health indicators.

\section{Physical Properties}

\section{Bulk Density:}

Soil cores were taken in the field using a 3-inch diameter metal ring at a depth of $0-7.5 \mathrm{~cm}$. 
The cores were air dried and weighed. Dry bulk density was calculated using Equation 4:

$$
\rho=\frac{\text { Soil dry weight }(\mathrm{g})}{\text { cylinder volume }\left(\mathrm{cm}^{3}\right)}
$$

\section{Saturated Hydraulic Conductivity:}

A single 6-inch diameter metal ring was inserted into the ground to a depth of three inches and was uncovered and lined with a thin plastic. Once lined, $444 \mathrm{ml}$ of distilled water was measured using a graduated cylinder and poured into the plastic-lined ring. The plastic was removed, and the time it took for the water to infiltrate the soil was recorded. The process was repeated for a second recording.

\section{Aggregate Stability:}

Aggregate stability was measured by using the air-dried bulk density sample and sieving 10 $\mathrm{g}$ of soil to $2 \mathrm{~mm}$ and placing the sample in a $0.25 \mathrm{~mm}$ sieve on a damp cloth to allow slow wetting for 5 minutes. The wet sample in the $0.25 \mathrm{~mm}$ sieve was then placed in a container filled with distilled water, so that the water surface is just above the soil. The sieve was then moved up and down at a rate of 30 oscillations per minute for three minutes. The sieve holding the sample was then placed on a dry cloth and then moved to a drying chamber. Once dry and cool, the remaining aggregates were weighed. The aggregates in the sieve were then immersed, soaked, and moved up and down in a Calgon solution for 5 minutes. The remaining sand was then rinsed, dried, and weighed. Water stable aggregates were then calculated by using Equation 5:

$$
\% \text { of soil }>0.25 \mathrm{~mm}=\frac{(\text { weight of dry aggregates }- \text { sand })}{(\text { weight of dry soil }- \text { sand })} \times 100
$$




\section{Slaking:}

Aggregate integrity under rapid wetting was measured using the slake test. Sixteen air- dry aggregates of the same size were placed on sieves and submerged into water for five minutes. After being submerged, aggregates were observed and classes 1 and 2 were determined based on loss of structural integrity. The sieves were then lifted up and down five times, observed, and classes $3,4,5$, and 6 were determined based on the percentage of soil remaining on the sieve.

\section{Chemical Properties}

\section{Soil pH and EC:}

Soil $\mathrm{pH}$ and EC were measured using the same 1:1 solution of air-dry soil from the bulk density sample and water measured with a scoop of known volume. The solution was shaken 25 times by hand. A pocket meter was used to measure EC while continuously stirring the solution. The sample was then set aside for 15 minutes to settle. A pocket meter was then used to measure $\mathrm{pH}$.

\section{Biological Properties}

\section{Soil Respiration:}

The same installed metal ring used in the soil respiration method above was used and capped with a plastic lid for 30 minutes. After the 30 minutes, Draeger tube and syringe were used to draw $100 \mathrm{cc}$ from the headspace within the ring. Four additional readings were performed if the first reading was less than $0.5 \%$, for a total of $500 \mathrm{cc}$. Respiration was calculated using Eq. 6 :

$$
R E S P=P F \times T F \times(\% C O 2-0.035) \times 22.91 \times H \quad \text { Eq. } 6
$$

where $P F=$ pressure factor $=1, T F=$ temperature factor $=($ soil temperature in Celsius +273$)$

$\div 273, H=$ inside height of ring $=5.08 \mathrm{~cm}$ (2 inches) 


\section{Vegetation Sampling: Survey, Methodology and Analysis}

Vegetation sampling and characterization was performed for Experiments II and III. A species diversity (speciation) survey was conducted at each of the fifty (50) GPS points for Experiment II, and in triplicates for both the treatment and control on all three sites using a 0.36 $\mathrm{m}^{2}$ quadrant grid in Experiment III. The quadrant that was used consisted of 156 "cells". To determine percent surface cover, dead material, canopy cover, occurrence of species within grass, legume, and forb classifications, and presence of moss, cells containing those characteristics were counted and divided by the total number of cells. All woody species were disregarded from the survey.

In Experiment III, once visual diversity surveys were completed, aboveground biomass was harvested using the $0.36 \mathrm{~m}^{2}$ quadrant grid at the eighteen points within the randomized block design at each site twice, in June 2017 and 2018, before urea application. Twelve weeks after urea application in September 2017 and 2018, the measurements were repeated.

Biomass for experiments 2 and 3 were harvested with garden shears at soil or ground level. The plant material was placed in paper bags and transported to the lab to be oven-dried at $60^{\circ} \mathrm{C}$ for $48 \mathrm{hrs}$. The collected biomass was weighed and recorded.

\section{Experimental Design and Data Analysis}

\section{Experiment I}

Results for Experiment I was statistically analyzed using SAS 9.2 (SAS Institute Inc., 2009). A Proc MEANS analysis was run to determine descriptive statistics for all soil indicators by method (NRCS, standard), and by site (WV2, WV11, WV16, WV32) x method (NRCS, standard). 
A simple linear correlation analysis was performed among all soil indicators using Proc CORR procedure by method, and by site and method.

A PROC GML procedure was used to run a completed randomized factorial analysis to separate Soil Health Indicators means for each method and site. The results of the mean separation obtained using t-test (LSD) by methods and site, was used to compare site separation between methods, or sensitivity of the method to separate sites. An alpha level of 0.10 was considered significant (Stoddard et al., 1998).

To test the effectiveness of methods that used the same units to describe the indicators (e.g. bulk density in $\mathrm{Mg} \mathrm{m}^{-3}$ ), a straight-line comparison of slopes and intercepts was developed. The standard method was considered the model or ideal regression line to mirror, and it determined the 1:1 line $(\mathrm{x}=\mathrm{y}$, and equal to standard method data). The procedure PROC REG was used to determine the significance of the regression parameters for the regression between methods, and PROC MIX procedure was used to determine if the regression between model was statistically similar (equal slopes) to the "ideal 1:1" regression line.

\section{Experiment II}

Statistical analyses were performed using SAS 9.2 (SAS Institute Inc., 2009). A Proc MEANS analysis was applied to determine descriptive statistics for all soil indicators and vegetation survey data by site (WV2, WV11, WV16) and by year $(2017,2018)$. A simple linear correlation analysis was performed on all soil indicators and vegetation survey data using Proc CORR by site. This analysis determined whether aboveground vegetation correlated to belowground soil indicators between sites.

A PROC GML procedure was used to run a completed randomized analysis to separate Soil Health Indicators means (including vegetation analysis/plant diversity) for each the site. The 
results of the mean separation obtained using t-test (LSD) by site, was used to compare effects of time since reclamation. A PROC ANOVA procedure was used to run a completed randomized analysis to separate vegetation analysis/plant diversity means for each the site and year. Two years of vegetation characteristics were taken through the duration of this study. This analysis determined whether the site and year of observation had an effect on vegetation diversity. An alpha level of 0.10 was considered significant (Stoddard et al., 1998).

\section{Experiment III}

Statistical analyses were performed using SAS 9.2 (SAS Institute Inc., 2009). The experimental design was a completely randomized block design $3 \times 2 \times 3$ (factors were 3 sites, 2 fertilizer rates, and 3 blocks). Proc MEANS procedure was run to obtain descriptive statistics for all soil indicators, vegetation survey data, and aboveground biomass by site (WV2, WV11, WV16) and by treatment (no fertilizer, fertilizer).

A simple linear correlation analysis (PORC CORR) was performed on all soil indicators, vegetation survey data, and aboveground biomass by site.

An PROC ANOVA with mean separation (t-test) were used to determine mean separation of soil health indicators and vegetation diversity/biomass among main effects (site or year of reclamation, fertilizer rate and block effects), and possible interactions. An alpha level of 0.10 was considered significant (Stoddard et al., 1998). 


\section{CHAPTER 4. RESULTS AND DISCUSSION}

\section{Experiment I: Soil Quality Test Kit Evaluation}

\section{Physical Properties}

\section{Bulk Density (BD)}

Bulk density (BD) was measured using the NRCS Soil Quality Test Kit method (core with known volume) and standard method (excavation) on each of the four mine sites. To compare the performance of the NRCS Soil Quality Test Kit to the standard method (excavation method) we consider a 1:1 "ideal" linear regression constructed using the standard method data as $\mathrm{x}$ and $\mathrm{y}$ variables (independent and dependent variables). The deviations of the NRCS Soil Quality Test Kit vs standard method regression line from the 1:1 was used to statistically evaluate the NRCS Soil Quality method. Figure 6 shows graphically the deviation between regression lines.

Statistically, the overall (all sites, all points) regression between the NRCS test kit method and standard method deviated significantly from the slope of the 1:1 line $(p=0.0012)$. However, there is a positive, but weak, relationship between the two methods with an $\mathrm{R}^{2}=0.32$ (significant at $p<0.01$ ). Figure 7 a through $\mathrm{d}$, shows the results for the same analysis described above executed for each site. The regression coefficients vary between 0.7 and 0.03 , indicating significant differences between the efficiency of the NRCS method by site, including a significant negative correlation for site WV16 $(r=-0.81)$. Site WV2 was the only site that

showed a strong positive correlation between the two methods with $\mathrm{R}^{2}=0.70$ (significant at $p<$ $0.01)$.

In general, the BD values found by the NRCS test kit method were found to be lower than all BD values (Table 3). The differences between $\mathrm{BD}$ data measured by the two methods may be 
due to the fact that the two methods were measured at different depths. The soil test kit method was measured between $0-7.5 \mathrm{~cm}$, whereas the standard method was measured between $0-15 \mathrm{~cm}$. The standard method uses a sampling depth 0-15 $\mathrm{cm}$ (approximately 6 inches) which is the depth at which soils are being evaluated for agricultural production (Follett et al., 1984). Bulk density is known to increase with depth (Pena-Yewtukhiw et al., 2009), and therefore higher bulk density values using the standard method were expected. The test kit method which samples 0$7.5 \mathrm{~cm}$, includes more volume of root mass in the total sample, which decreases the total mass weight of sample resulting in lower bulk density.

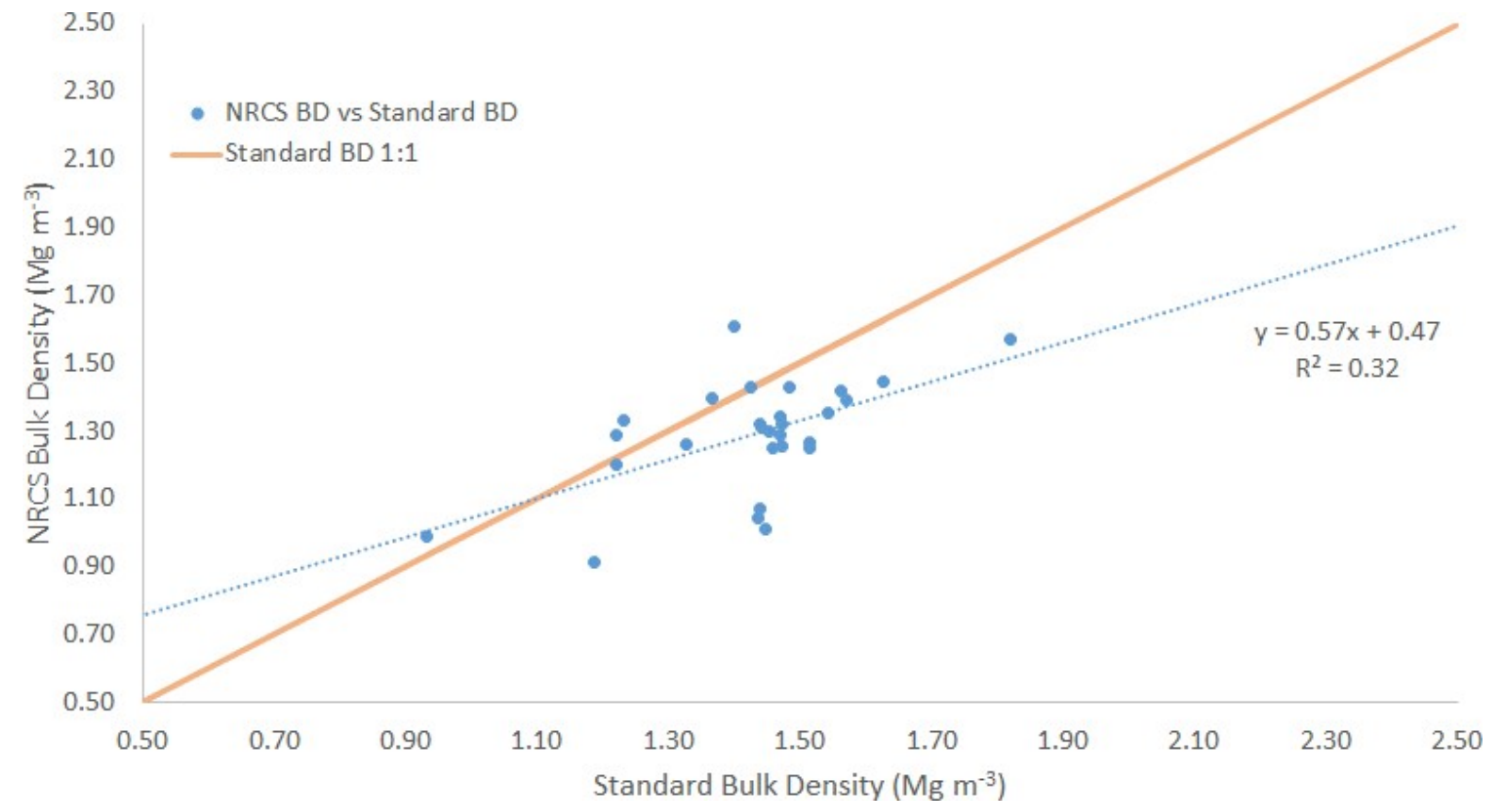

Figure 6. Overall (all sites) comparison of soil bulk density obtained with the standard and NRCS methods. 
a.

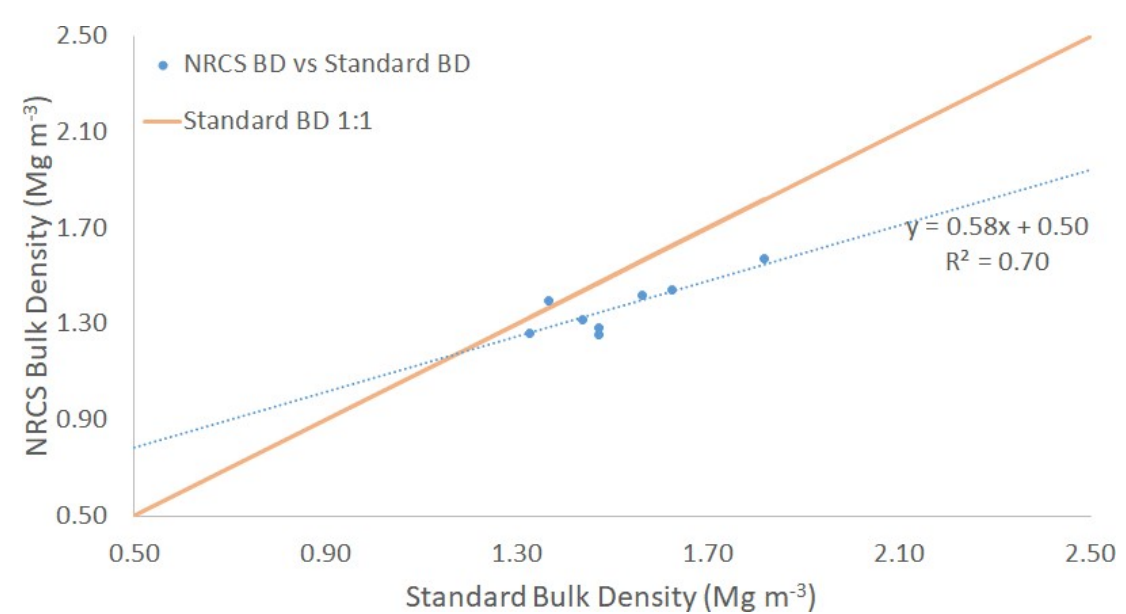

c.

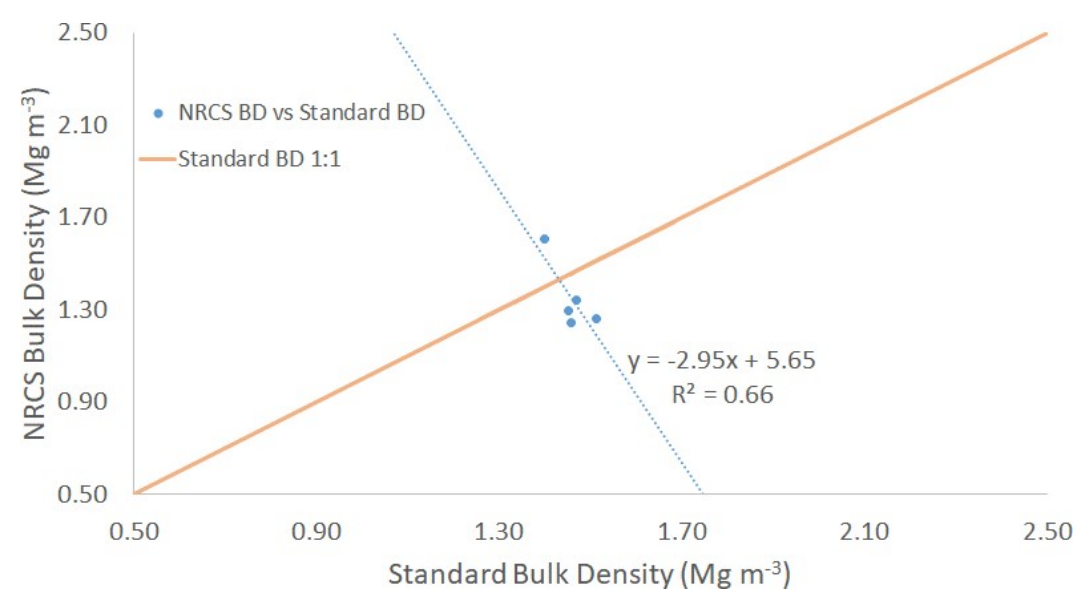

b.

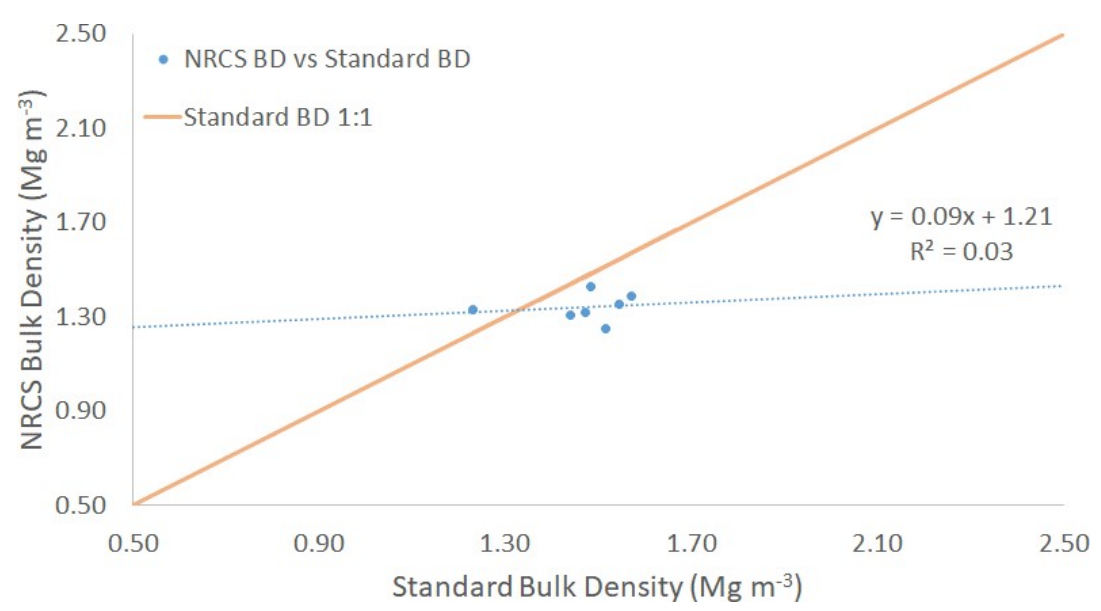

d.

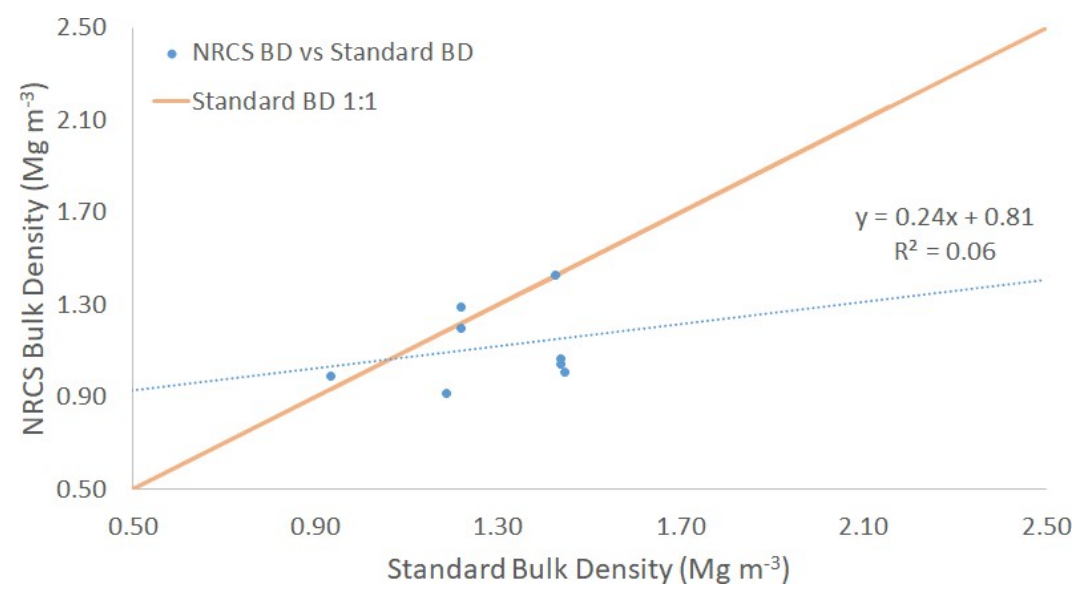

Figure 7. Comparison of soil bulk density obtained with the Standard and NRCS methods by site: 7a. WV2, 7b. WV11, 7c. WV16, and $7 \mathrm{~d}$. WV32. 
Bulk density exhibited significant differences between the youngest and oldest sites (Table 3). In general, and for both $\mathrm{BD}$ measuring methods, the significant difference between the youngest and oldest site, with the youngest site having the highest BD and the oldest site with the lowest $\mathrm{BD}$, may be due to the recent high compaction in the youngest site and soil development and vegetation establishment in the oldest site (Table 3).

Using the NRCS method, sites WV2, WV11, and WV16 showed no statistical difference with values of $1.37 \pm 0.11 \mathrm{Mg} \mathrm{m}^{-3}, 1.34 \pm 0.06 \mathrm{Mg} \mathrm{m}^{-3}$, and $1.35 \pm 0.15 \mathrm{Mg} \mathrm{m}^{-3}$, respectively. However, WV32 showed the lowest value of $1.12 \pm 0.17 \mathrm{Mg} \mathrm{m}^{-3}$ and was statistically significant from the other sites, which was expected due to the older age of the site (more root mass and organic matter accumulation). Although the NRCS and the standard method BD data followed a similar trend, the standard method exhibited a higher sensitivity in the statistical separation between sites (Table 3). The standard method data resulted in WV2 having the highest value of $1.53 \pm 0.15 \mathrm{Mg} \mathrm{m}^{-3}$ and WV32 having the lowest value of $1.37 \pm 0.32 \mathrm{Mg} \mathrm{m}^{-3}$. However, sites WV11 and WV16 were not statistically different from either WV2 or WV32, with values of $1.48 \pm 0.12 \mathrm{Mg} \mathrm{m}^{-3}$ and $1.45 \pm 0.11 \mathrm{Mg} \mathrm{m}^{-3}$, respectively.

The BD values for both methods were similar to those found by Bendfeldt et al. (2001) which were taken at a depth of 0 to $10 \mathrm{~cm}$. The soil test kit method resulted in lower BD values found by Mukhopadhyay et al. (2016), however the standard method resulted in similar values reported for $\mathrm{BD}$ at a depth of 0 to $15 \mathrm{~cm}$. The observed results were lower than those reported by Thurman and Sencindiver (1986) for uncorrected BD which were taken from the A horizon of mine soils ( 0 to $9 \mathrm{~cm}$, and 0 to $12 \mathrm{~cm}$ depths). The $\mathrm{BD}$ values found in this study, were more like those reported for corrected BD. 
Table 3. Differences in soil bulk density $\left(\mathrm{Mg} \mathrm{m}^{-3}\right)$ obtained with standard and NRCS methods between sites at an $\alpha$ level of 0.10 .

\begin{tabular}{ccc} 
Site & $\begin{array}{c}\text { Soil Test Kit } \\
\text { BD }\end{array}$ & Standard BD \\
& \multicolumn{2}{c}{$\mathrm{Mg} \mathrm{m}^{-3}$} \\
WV2 & $1.37 \pm 0.11 \mathrm{a}$ & $1.53 \pm 0.15 \mathrm{a}$ \\
WV11 & $1.34 \pm 0.06 \mathrm{a}$ & $1.48 \pm 0.12 \mathrm{ab}$ \\
WV16 & $1.35 \pm 0.15 \mathrm{a}$ & $1.45 \pm 0.11 \mathrm{ab}$ \\
WV32 & $1.12 \pm 0.17 \mathrm{~b}$ & $1.37 \pm 0.32 \mathrm{~b}$ \\
\hline
\end{tabular}

Note: Different letters in the columns indicate significant differences between sites within methods.

Regarding agricultural soils, the soil BD measured in the WV2, WV11 and WV16 regardless of the method represent moderate limitations for general agricultural activities (NRCS-USDA, 2014). Site WV16 exhibited slight to no limitations when NRCS method was used, but the same limitations as the other sites when the standard method was used.

\section{Saturated Hydraulic Conductivity $\left(K_{s}\right)$}

Saturated hydraulic conductivity was measured and compared using the NRCS Soil Quality Test Kit (single ring) and standard method (Wooding Infiltrometer) on all four sites. To compare the performance of the NRCS Soil Quality Test Kit to the standard method, the same procedure used for BD was applied for the saturated hydraulic conductivity: considering a 1:1 "ideal" linear regression constructed using only the standard method data, and measuring the statistically significant deviations from the NRCS Soil Quality Test Kit vs standard method regression line.

There is a weak but significant correlation between the two methods with $\mathrm{R}^{2}=0.13$ (Figure 8). However, the slope of the trendline of the NRCS test kit vs standard method deviate significantly from the ideal 1:1 line $(p<0.0001)$. The two methods are not statistically 
comparable.

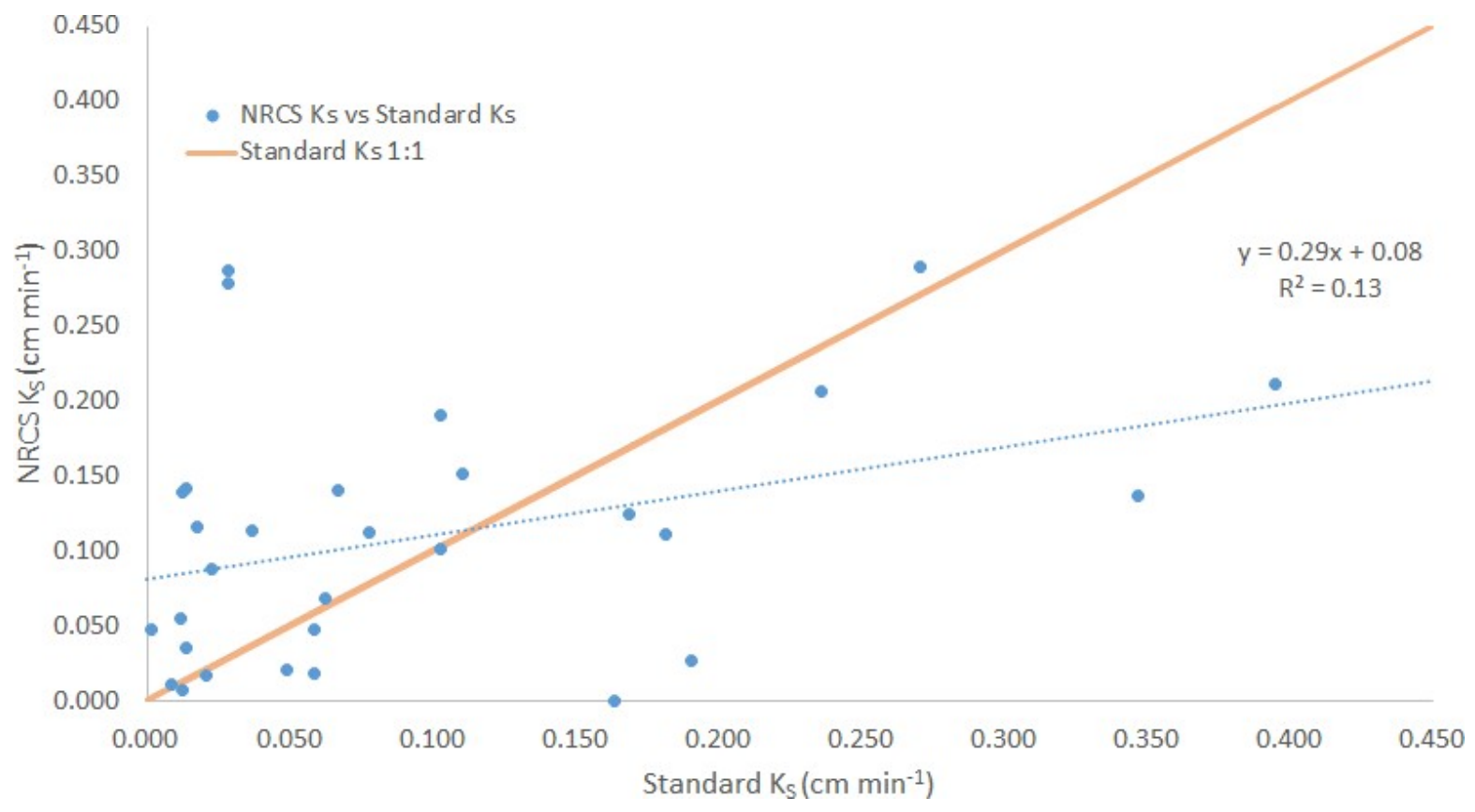

Figure 8. Overall (all sites) comparison of saturated hydraulic conductivity obtained with the Standard and NRCS methods.

Figure 9 shows that the relationship between the NRCS test kit and standard method deviated significantly from the slope of the 1:1 line on WV2, WV11, and WV16 with p values of $0.0003,0.0205,0.0169$, respectively. Site WV32 had a $p=0.0519$, however it is negatively correlated. Site WV16 shows a strong positive correlation between methods with $\mathrm{R}^{2}=0.72$, and the best efficiency between methods of all the sites.

Using the soil test kit, saturated hydraulic conductivity showed no statistical difference between WV32 and WV16 with values of $0.175 \mathrm{~cm} \mathrm{~min}^{-1}$ and $0.144 \mathrm{~cm} \mathrm{~min}^{-1}$, respectively (Table 4). Sites WV2 and WV11 showed no statistical difference with values of $0.077 \mathrm{~cm} \mathrm{~min}^{-1}$ and $0.073 \mathrm{~cm} \mathrm{~min}^{-1}$, respectively. The standard method showed a similar trend with sites WV2, WV11 and WV16 with values $0.073 \mathrm{~cm} \mathrm{~min}^{-1}, 0.075 \mathrm{~cm} \mathrm{~min}^{-1}$, and $0.175 \mathrm{~cm} \mathrm{~min}^{-1}$, respectively. 
However, WV32 showed a value of $0.114 \mathrm{~cm} \mathrm{~min}^{-}$which was not significantly different compared to WV2 and WV11 or WV16. Table 2 presents the hydraulic conductivity data for all sites and their evident high standard deviation. Saturated hydraulic conductivity is characterized by exhibiting a high variation due to textural and structural heterogeneity of soils within the same site (García-Gutiérrez et al., 2018; Gamie and Smedt, 2018).

Despite the slopes deviation between regression lines shown in Figures 8 and 9, the average NRCS test kit Ks and standard Ks show similar trends of the youngest sites having lower Ks than that of the older sites. These results may be due to higher compaction in the younger sites limiting water movement in the soil surface (Gregory et al., 2006). The results from the study sites show higher Ks values than those reported by Thurman and Sencindiver (1986), and lower values compared to Pedersen et al. (1980). Overall, the soil test kit average Ks seems to be representative of the standard method in each site. However, the NRCS and the standard method followed a similar drift in the data by site, the standard method exhibited a higher sensitivity in the statistical separation between sites (Table 4). 
a.

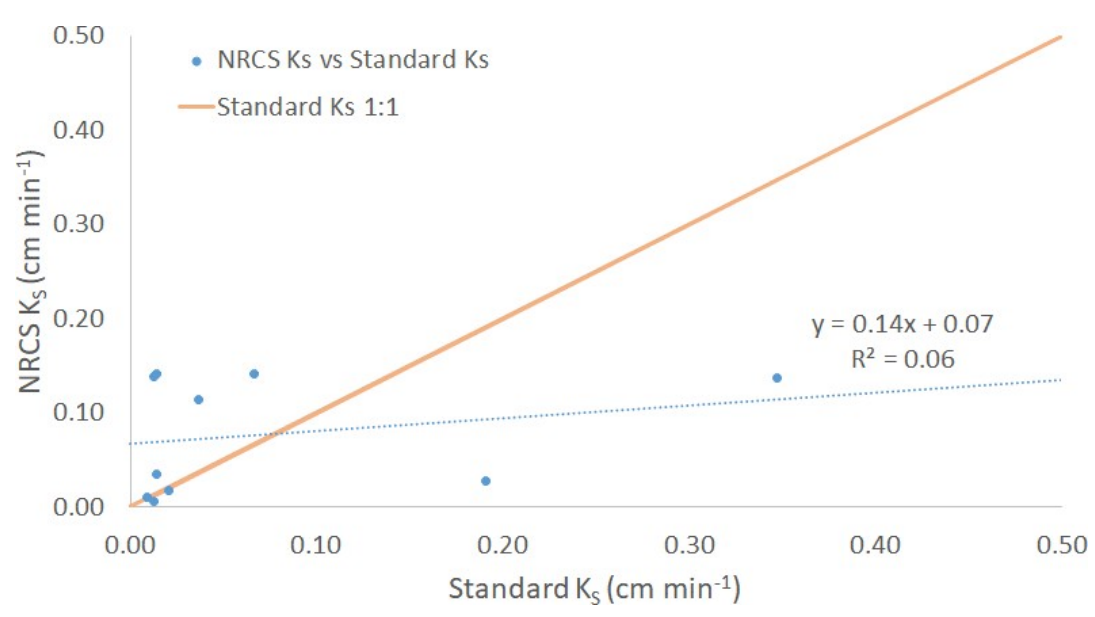

c.

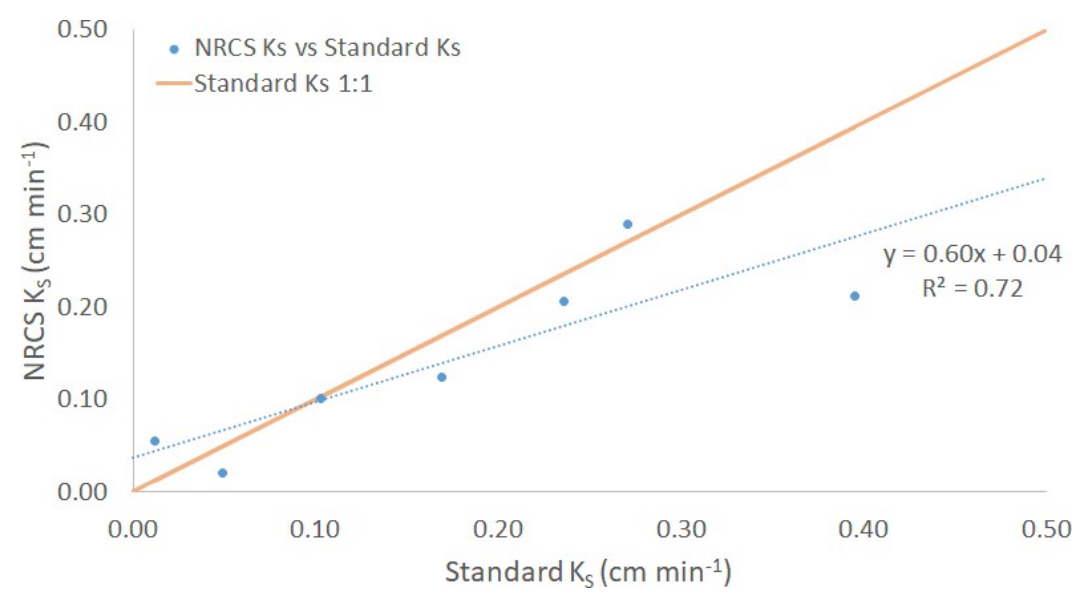

b.

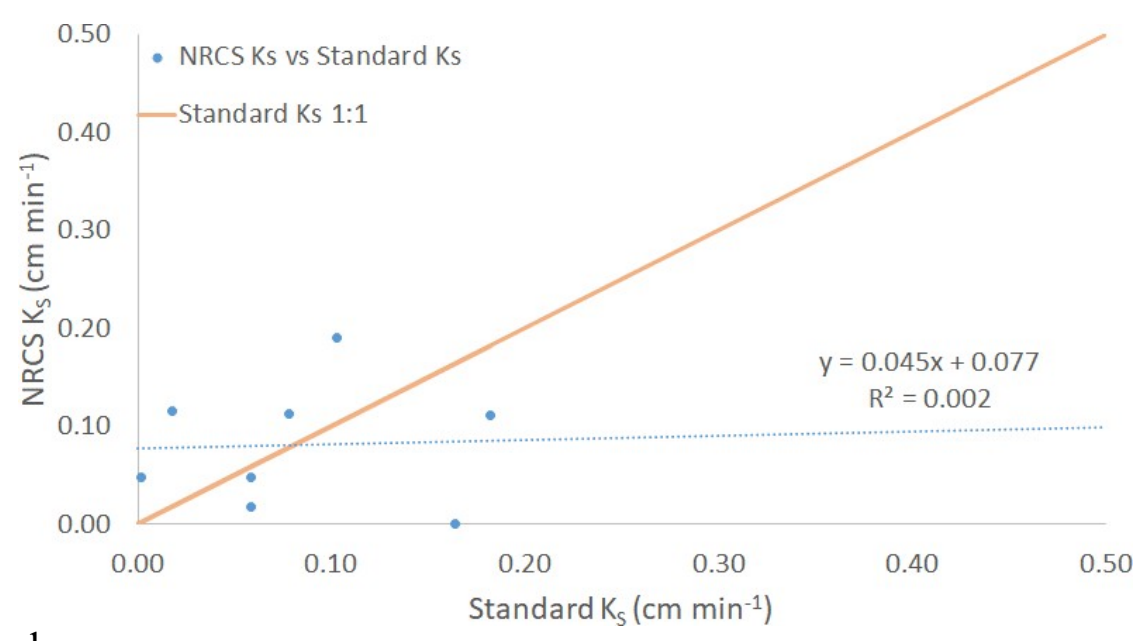

d.

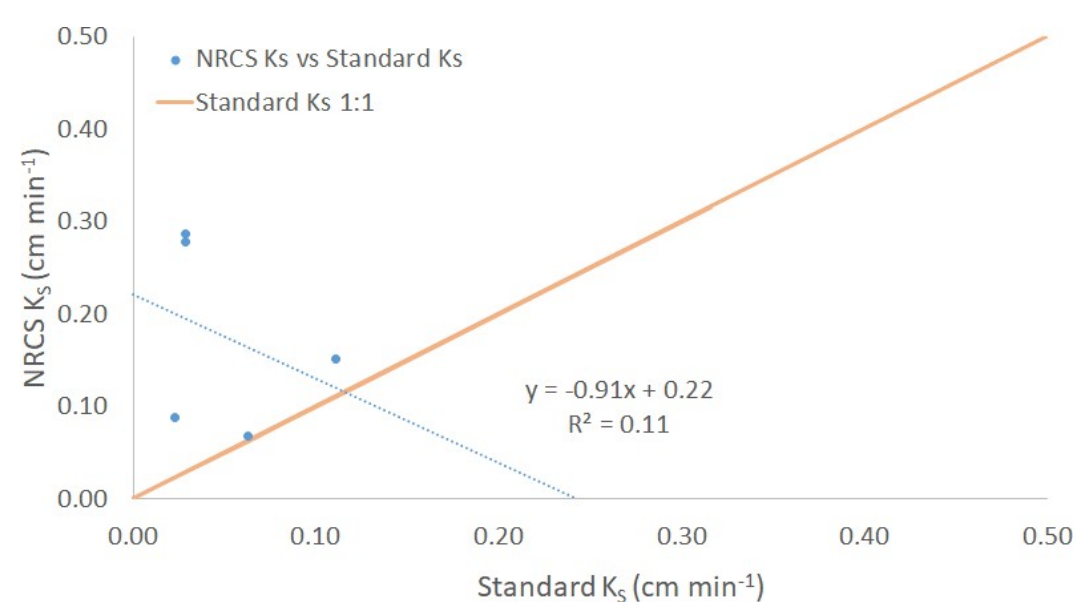

Figure 9. Comparison of saturated hydraulic conductivity obtained with the Standard and NRCS methods by site: $9 \mathrm{a}$. WV2, 9b. WV11, 9c. WV16, and 9d. WV32 
Table 4. Differences in saturated hydraulic conductivity $\left(\mathrm{cm} \mathrm{min}^{-}\right)$obtained with standard and NRCS methods between sites at an $\alpha$ level of 0.10 .

\begin{tabular}{ccc} 
Site & $\begin{array}{c}\text { Soil Test Kit } \\
\mathbf{K}_{\mathbf{s}}\end{array}$ & Standard Ks \\
\hline cm min & \multicolumn{2}{c}{$\mathrm{cm}^{-1}$} \\
WV2 & $0.077 \pm 0.062 \mathrm{~b}$ & $0.073 \pm 0.111 \mathrm{~b}$ \\
WV11 & $0.073 \pm 0.064 \mathrm{~b}$ & $0.094 \pm 0.068 \mathrm{~b}$ \\
WV16 & $0.144 \pm 0.096 \mathrm{a}$ & $0.175 \pm 0.114 \mathrm{a}$ \\
WV32 & $0.175 \pm 0.104 \mathrm{a}$ & $0.114 \pm 0.099 \mathrm{ba}$
\end{tabular}

Note: Different letters in the columns indicate significant differences between sites within methods.

The surface soil hydraulic conductivity measured in WV2 and WV11 are considered to be moderate (USDA, 2019) for general soil agricultural uses regardless of the method. However, for the older sites (WV16 and WV32) moderate rapid conductivities. These values relate to the soil bulk density and to wet aggregate stability of the sites. In high BD sites, hydraulic conductivity decreased (Pachepsky and Park, 2015), and wet aggregate stability increased with time since reclamation, increasing the water conductance under saturated conditions.

\section{Aggregate Stability (WA)}

Standard methods to determine wet aggregate stability in the lab have no direct comparison with the slaking or the aggregation method included in the NRCS Soil Quality Test Kit. In this document the data obtained by the qualitative method were presented in table format (Table 5). The general conclusion was that there was a similar trend between all three methods. The oldest site was found to have the highest wet aggregate stability, whereas the youngest site had the least wet aggregate stability. The NRCS soil test kit aggregate stability test was more sensitive to separate water-stable aggregates between sites, followed by the standard method. The least 
sensitive was the NRCS soil test kit slaking method, with only two classes of separation.

Table 5. Differences in aggregate stability obtained with standard and NRCS methods between sites at an alevel of 0.10 .

\begin{tabular}{cccc} 
Site & $\begin{array}{c}\text { Soil Test Kit } \\
\text { WA }\end{array}$ & $\begin{array}{c}\text { Soil Test } \\
\text { Kit } \\
\text { Slaking }\end{array}$ & $\begin{array}{c}\text { Standard } \\
\text { WA }\end{array}$ \\
\hline WV2 & $59.7 \pm 14.0 \mathrm{c}$ & $5.1 \pm 0.7 \mathrm{~b}$ & MWD \\
WV11 & $63.9 \pm 6.8 \mathrm{c}$ & $5.8 \pm 0.2 \mathrm{a}$ & $5.7 \pm 0.2 \mathrm{~b} \mathrm{~b}$ \\
WV16 & $72.5 \pm 7.3 \mathrm{~b}$ & $5.9 \pm 0.1 \mathrm{a}$ & $6.1 \pm 0.1 \mathrm{a}$ \\
WV32 & $80.6 \pm 5.1 \mathrm{a}$ & $5.9 \pm 0.1 \mathrm{a}$ & $6.0 \pm 0.4 \mathrm{a}$
\end{tabular}

Note: Different letters in the columns indicate significant differences between sites within method.

These results were expected and support the findings of water-stables aggregates increasing with time reported by Thomas et al. (2000) and Wick et al. (2009) due to increased soil development and SOM. However, the results using the soil test kit method of percent waterstable aggregates were higher than those found by Bendfeldt et al. (2001).

\section{Chemical Properties}

$$
\text { pH }
$$

Soil $\mathrm{pH}$ was measured using a the NRCS soil test kit method (pocket meter - Milwaukee pH600) and standard method (bench meter - Beckman 43) with both methods using a 1:1 soil water solution. In the overall site comparison of $\mathrm{pH}$ methods, a 1:1 linear regression was used to determine slope deviation $(p<0.01)$ of the two methods from the 1:1 linear regression of the standard method. Figure 10 shows the overall site comparison, which indicates that the trend line of the test kit and standard methods deviates from the $1: 1$ slope with a $p=0.0244$. If a significance level of $\mathrm{p}<0.01$ is applied, the deviation in data between methods is not significant. 
There is a strong positive correlation between the methods with an $\mathrm{R}^{2}$ value of 0.66 . Figure 11 shows the 1:1 linear regression comparison for all sites individually, where WV2 shows a deviating slope with a $p=0.0084$. All sites excluding WV2 show a positive correlation between the methods.

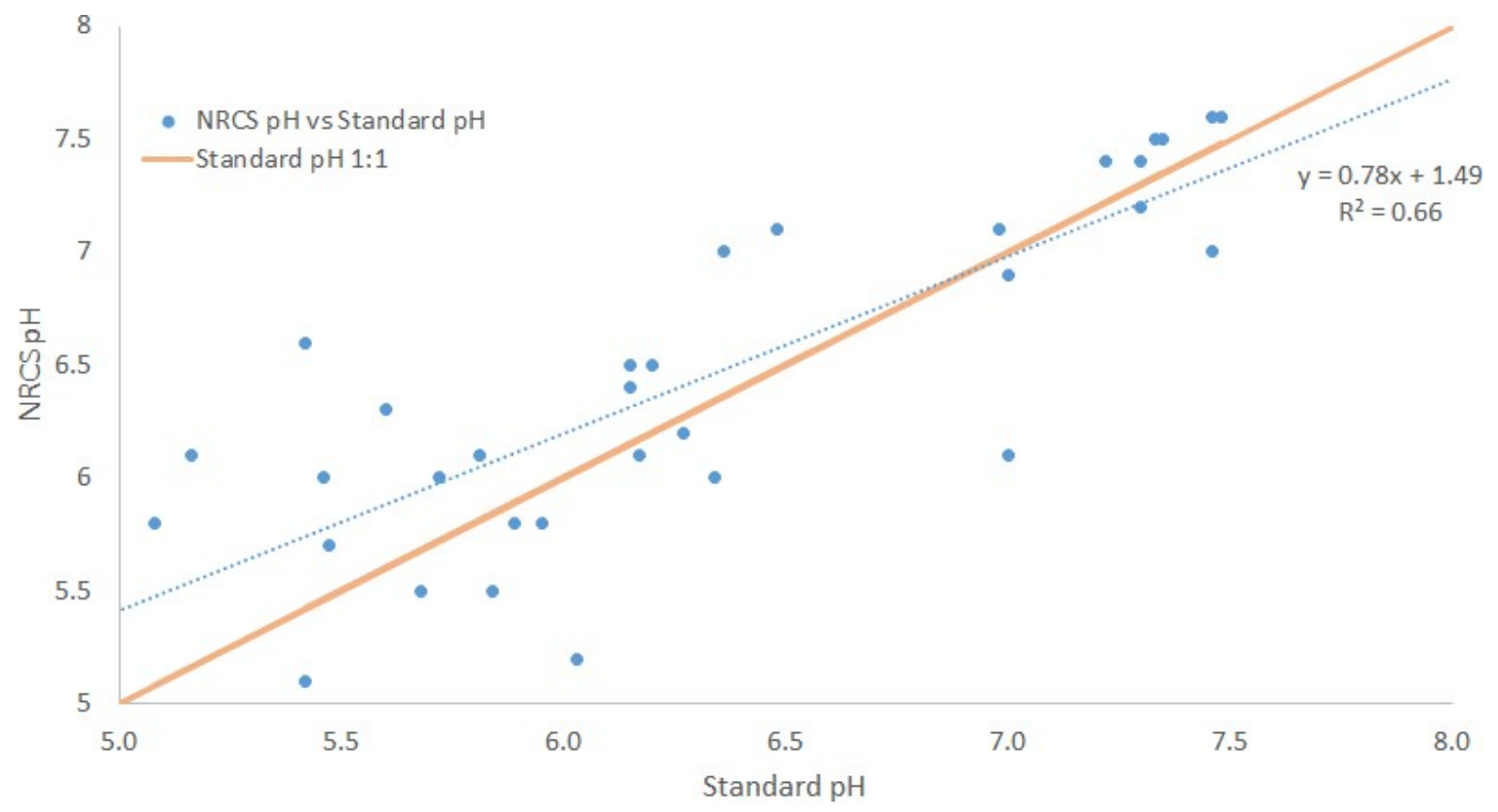

Figure 10. Overall (all sites) comparison of $\mathrm{pH}$ obtained with the Standard and NRCS methods.

Figure 11 shows the 1:1 linear regression comparison for individual sites, where WV2 shows a significant deviation from the $1: 1$ curve $(p=0.0084)$. The youngest site exhibits the greatest deviation between the standard laboratory test and the NRCS field pocket method. All sites excluding WV2 show a positive correlation between the methods. What has been observed for all the properties studies and methods studied at this time, is that there is an effect of site on how the method performs.

Soil pH shows a significant difference between the younger and older sites (Table 6).

Using both the soil test kit and standard $\mathrm{pH}$ methods, WV2 and WV 11 were significantly 
lower than WV16 and WV32. The two methods also show a significantly lower $\mathrm{pH}$ for WV16 compared to WV32. These results support the findings of Roberts et al. (1988), Hearing et al. $(1993,2004)$, and Thomas et al. (2000). The overall increase in soil $\mathrm{pH}$ with time is similar to the findings of Chaudhuri et al. (2012). Overall, the soil test kit average $\mathrm{pH}$ measurements are comparable to the $\mathrm{pH}$ measurements performed in the lab using the standard method. However, the standard method exhibited a higher sensitivity in the statistical separation between sites (Table 6).

Table 6. Differences in $\mathrm{pH}$ values obtained with standard and NRCS methods between sites at an $\alpha$ level of 0.10 .

\begin{tabular}{ccc} 
Site & $\begin{array}{c}\text { Soil Test Kit } \\
\mathbf{p H}\end{array}$ & $\begin{array}{c}\text { Standard } \\
\mathbf{p H}\end{array}$ \\
\hline WV2 & $6.0 \pm 0.4 \mathrm{c}$ & $6.1 \pm 0.5 \mathrm{bc}$ \\
$\mathbf{W V 1 1}$ & $5.8 \pm 0.4 \mathrm{c}$ & $5.8 \pm 0.5 \mathrm{c}$ \\
$\mathbf{W V 1 6}$ & $6.5 \pm 0.6 \mathrm{~b}$ & $6.3 \pm 0.6 \mathrm{~b}$ \\
$\mathbf{W V 3 2}$ & $7.3 \pm 0.3 \mathrm{a}$ & $7.3 \pm 0.3 \mathrm{a}$
\end{tabular}

Note: Different letters in the columns indicate significant differences between sites within method. 
a.

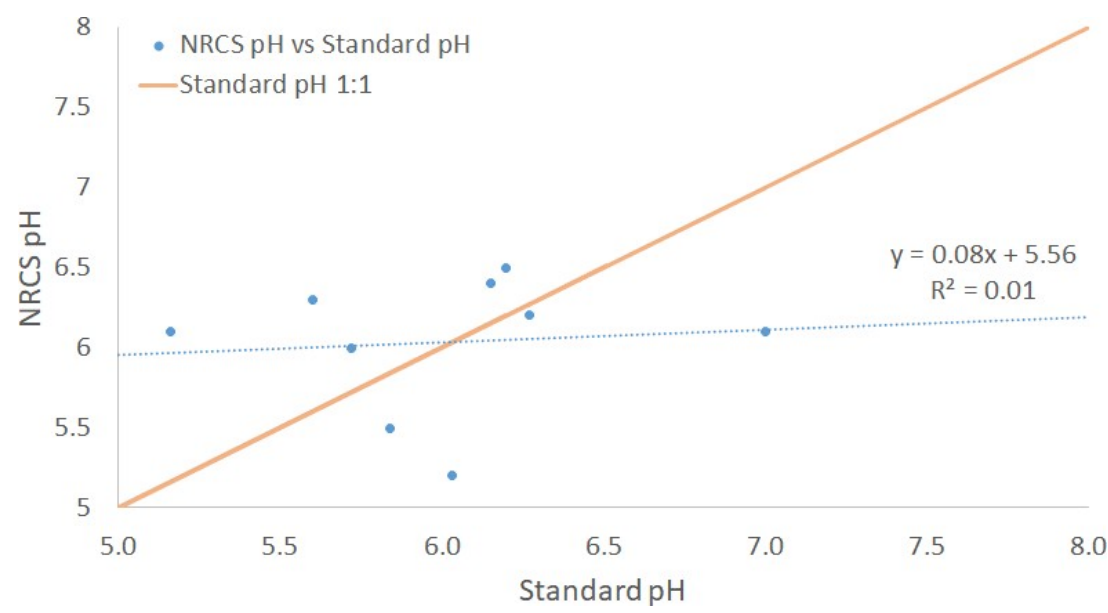

c.

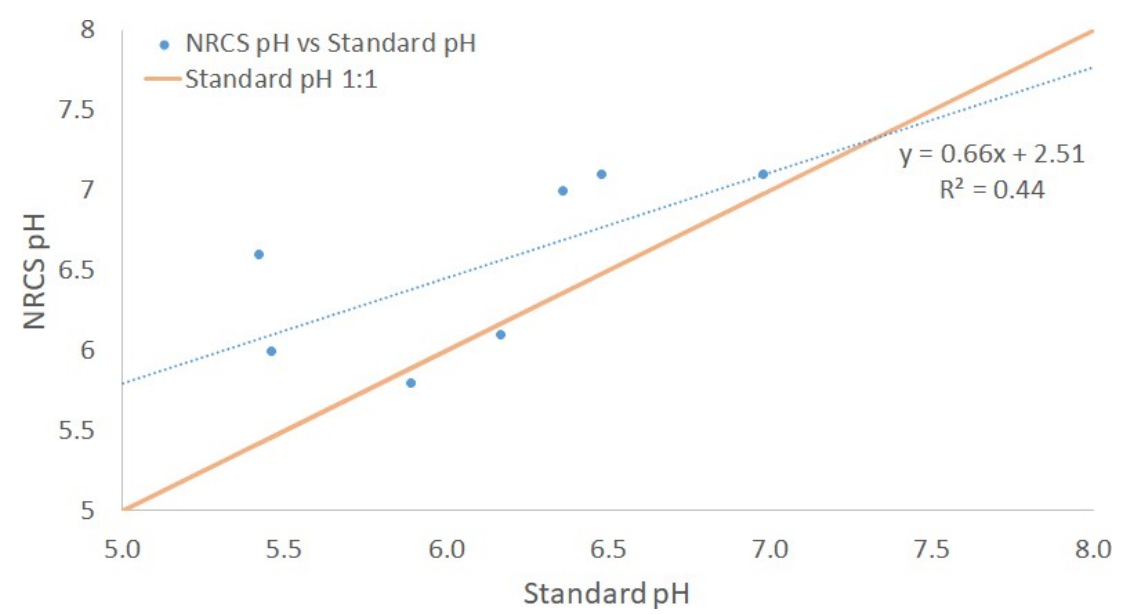

b.

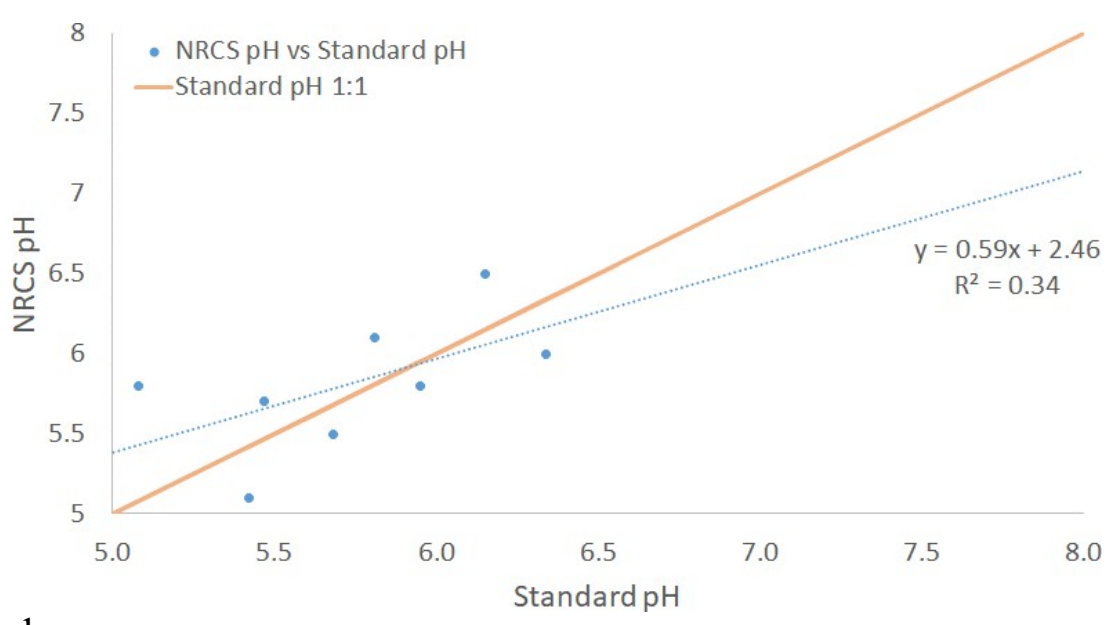

d.

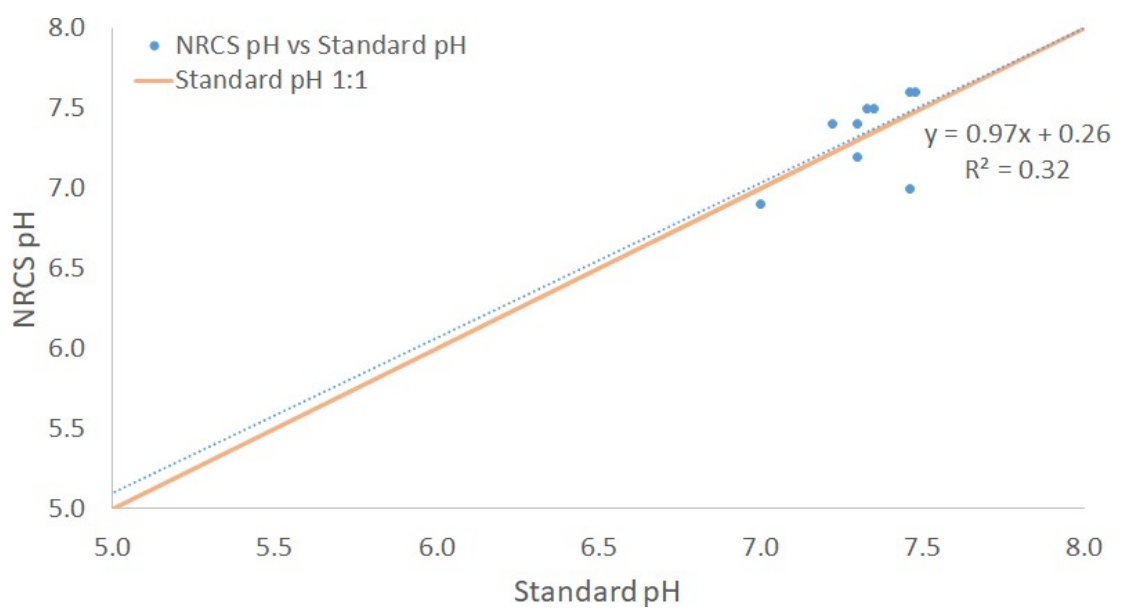

Figure 11. Comparison of $\mathrm{pH}$ obtained with the Standard and NRCS methods by site: 11a. WV2, 11b. WV11, 11c. WV16, and 11d. WV32 


\section{Electrical Conductivity (EC)}

Soil EC was measured using the NRCS test kit method (pocket meter - Hanna DiST4) and standard method (bench meter - Mettler Toledo S230 SevenCompact) using a 1:1 soil water solution. In the overall site comparison of NRCS Soil Quality Test Kit EC vs Standard EC regression, indicated a significant deviation from the ideal 1:1 regression line $(p<0.05)$. Figure 12 shows that the overall relationship of the test kit and standard method deviated from the slope of the $1: 1$ line $(p<0.0001)$. Figure 12 also shows that there is a weak positive correlation between the two methods with an $\mathrm{R}^{2}=0.13$. Figure 13 depicts the relationship of the two methods compared to the 1:1 linear relationship for each site individually. All sites, excluding WV11, shows a significant deviation from the slope of the 1:1 line. All four sites show weak to no correlation between the two methods.

These results may be contributed to the depth at which the soil sample was taken. The test kit method went to a depth $0-7.5 \mathrm{~cm}$, whereas the standard method used a depth of $0-15 \mathrm{~cm}$. In Shrestha and Lal (2011), it was seen that EC increased with depth. Other possible contributions are that the soil test kit method did not require the grinding of soil before the EC measurement was taken. The method also required shaking of the soil water solution for a very small amount of time by hand, and suggested stirring the solution with the EC meter to help keep the soil particles suspended. Even with the stirring of the solution, the pocket meter was not as sensitive as the laboratory meter resulting in lower EC values for all four sites.

The soil moisture content of the sample in the field is higher than the moisture content of the sample used in the laboratory determination of EC (Bai et al., 2013). In a study by Zhang and Weinhold (2002), $\mathrm{pH}$ and EC were measured under increasing moisture contents, resulting in a small decrease of $\mathrm{pH}$ followed by a rapid increase at a certain moisture content. However, EC 
reacted with constant increase with higher moisture content, followed by a rapid decline at the same moisture content that $\mathrm{pH}$ increased. The two measurements performed inversely of each other, however the results reported here have a strong positive correlation to one another for both methods, as $\mathrm{pH}$ increases EC increases $(\mathrm{p}<0.0001)$.

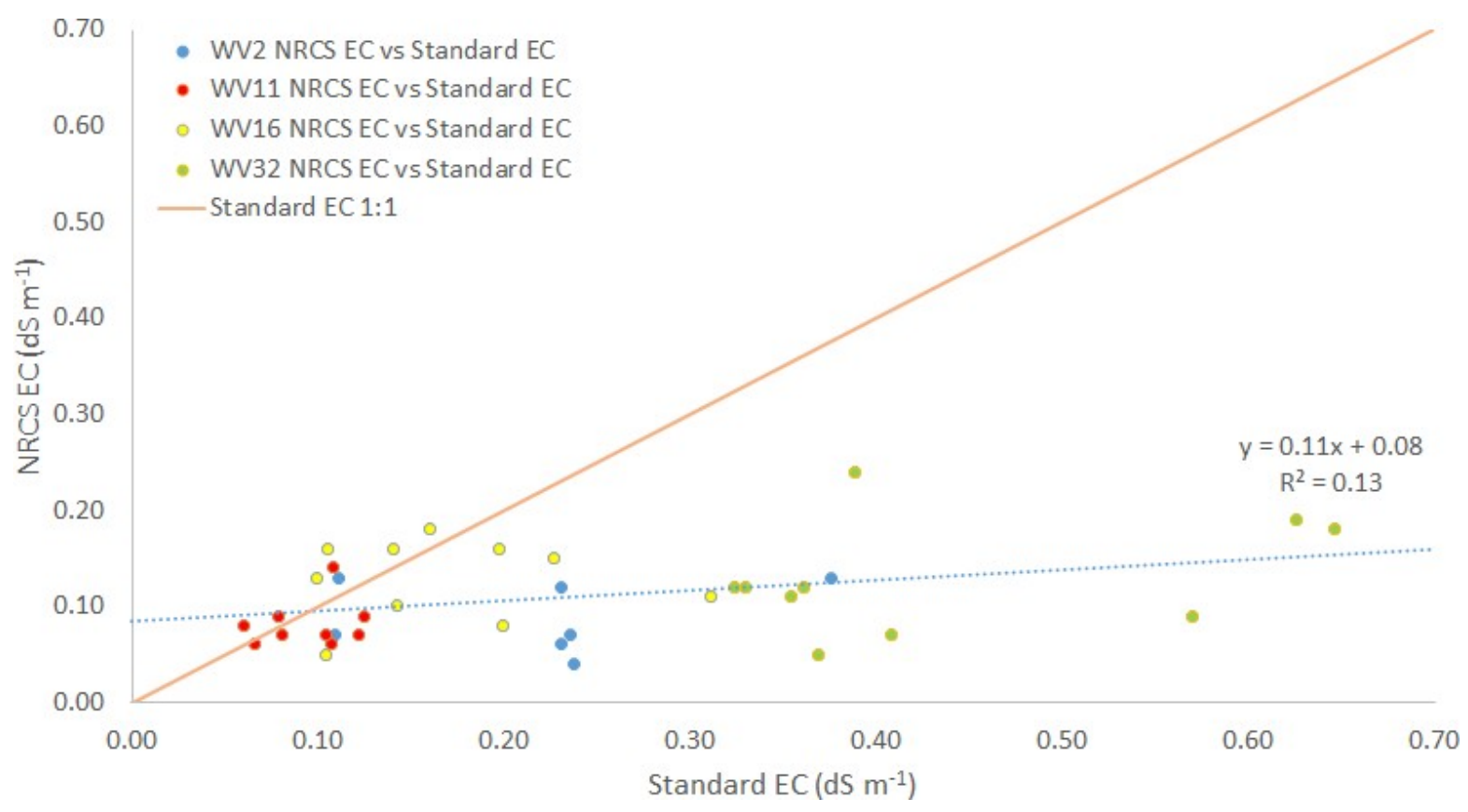

Figure 12. Overall (all sites) comparison of EC obtained with the Standard and NRCS methods. 
a.

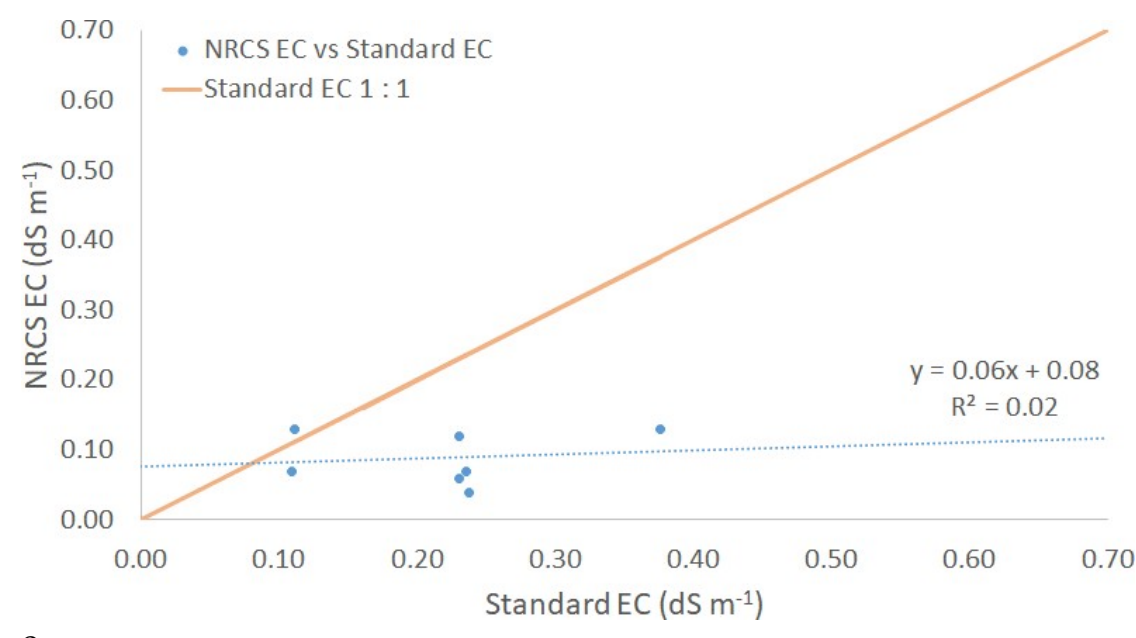

c.

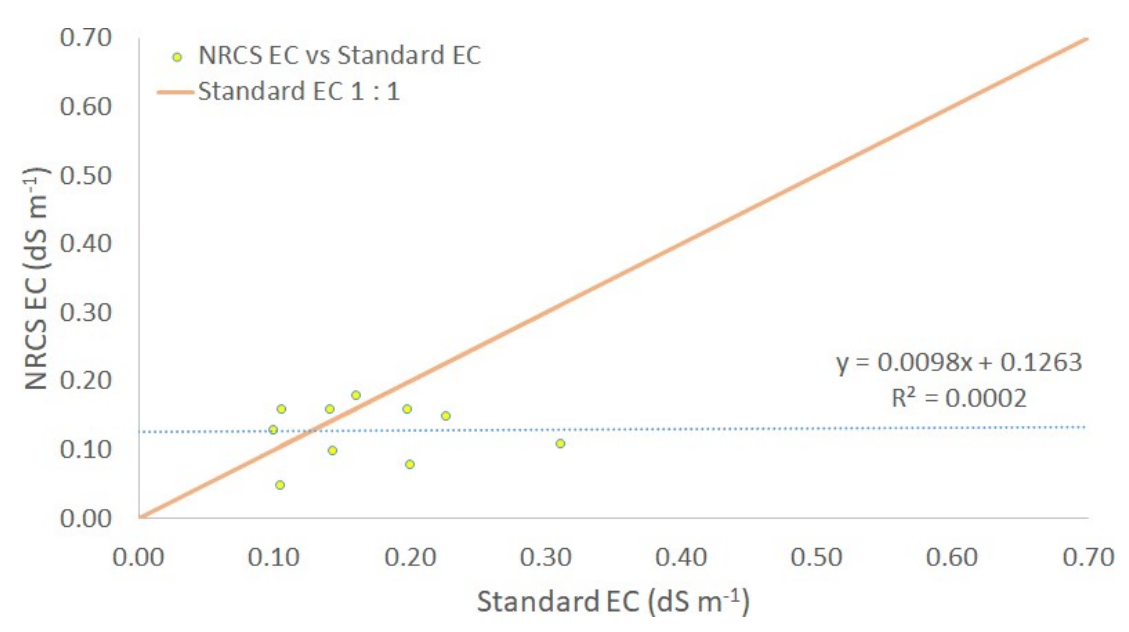

b.

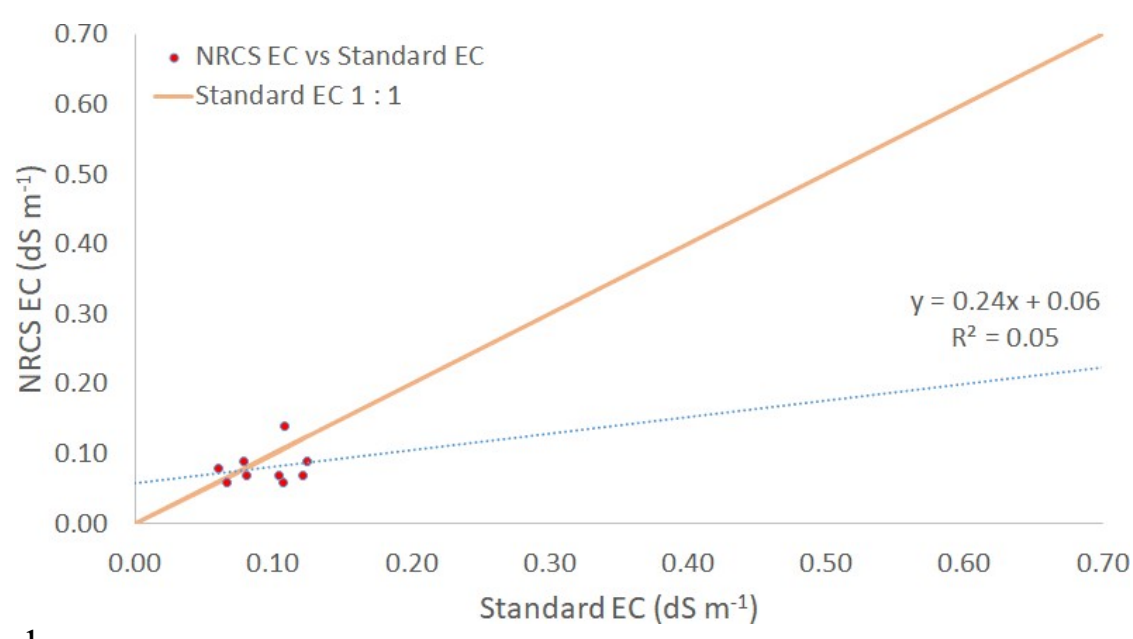

d.

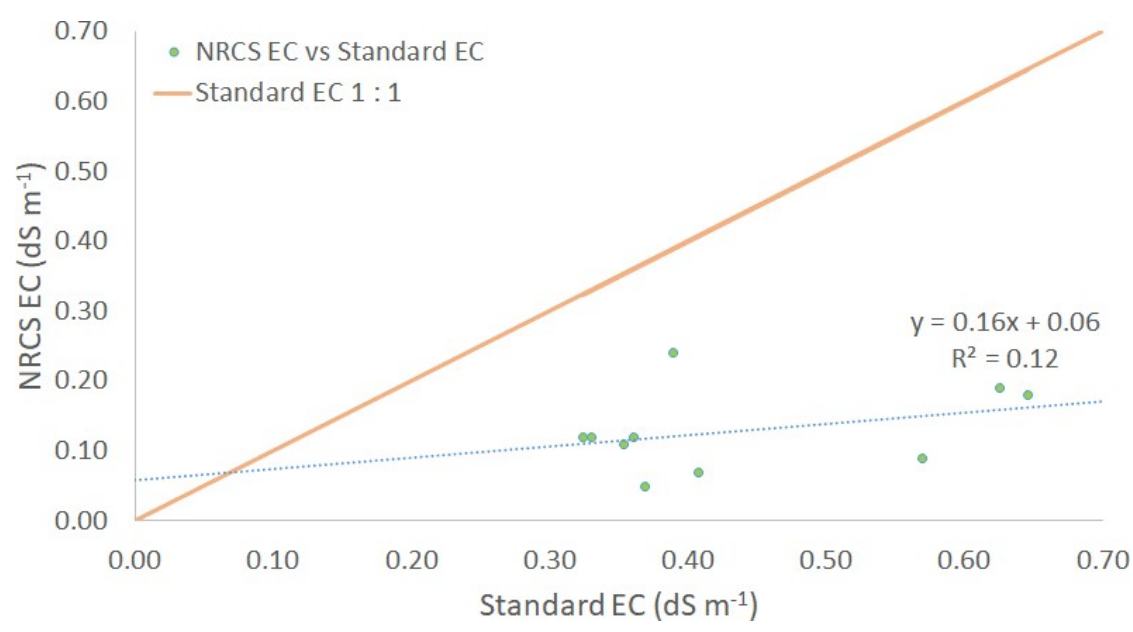

Figure 13. Comparison of EC obtained with the Standard and NRCS methods by site: 13a. WV2, 13b. WV11, 13c. WV16, and 13d. WV32 
Soil EC showed a significant difference between the youngest and oldest sites using the Soil Test Kit method (Table 7). Sites WV2 and WV11 were not significantly different with EC values of $0.089 \mathrm{dS} \mathrm{m}^{-1}$ and $0.081 \mathrm{dS} \mathrm{m}^{-1}$, respectively. Sites WV16 and WV32 were significantly higher than the two youngest sites with values $0.128 \mathrm{dS} \mathrm{m}^{-1}$ and $0.154 \mathrm{dS} \mathrm{m}^{-1}$, respectively. The standard method showed a similar trend with WV32 having the highest EC $\left(0.438 \mathrm{dS} \mathrm{m}^{-1}\right)$ and WV11 having the lowest EC $\left(0.097 \mathrm{dS} \mathrm{m}^{-1}\right)$. However, the standard method seemed to be more sensitive with values higher than the test kit method, discussed previously.

These EC ranges support the findings of Shrestha and Lal (2011), and Roberts et al. (1988). However, the increase of soil EC with time is opposite of the findings reported by Wick et al. (2009) and Chaudhuri et al. (2012), where soil EC decreased with time since reclamation. The dominant and mixed parent material of sandstone and shale may account for these discrepancies (Roberts et al., 1988)

Table 7. Differences in electrical conductivity (EC in $\mathrm{dS} \mathrm{m}^{-1}$ ) obtained with standard and NRCS methods between sites.

\begin{tabular}{ccc} 
Site & $\begin{array}{c}\text { Soil Test Kit } \\
\text { EC }\end{array}$ & Standard EC \\
& \multicolumn{2}{c}{$\mathrm{dS} \mathrm{m}^{-1}$} \\
WV2 & $0.089 \pm 0.037 \mathrm{~b}$ & $0.202 \pm 0.084 \mathrm{~b}$ \\
$\mathbf{W V 1 1}$ & $0.081 \pm 0.025 \mathrm{~b}$ & $0.097 \pm 0.023 \mathrm{c}$ \\
WV16 & $0.128 \pm 0.042 \mathrm{a}$ & $0.169 \pm 0.067 \mathrm{~b}$ \\
WV32 & $0.154 \pm 0.050 \mathrm{a}$ & $0.438 \pm 0.128 \mathrm{a}$
\end{tabular}

Note: Different letters in the columns indicate significant differences between sites within methods at an $\alpha$ level of 0.10 .

Regarding agricultural soils, the soil EC measured in all the sites regardless of the method represent slightly to no limitations for general agricultural activities (NRCS-USDA, 2014). 


\section{Biological Properties}

\section{Soil Respiration}

Soil respiration was measured using the NRCS Test Kit method (Draeger tubes) and standard method (Solvita ${ }^{\circledR}$ test, $\mathrm{CO} 2$-Burst) on each of the four sites. The average respiration rate and differences between methods are presented in Table 8. The Solvita results were transformed from mg kg-1 day-1 to ${\mathrm{lb} \mathrm{CO} 2-\mathrm{C} \mathrm{ac}^{-1} \text { day }}^{-1}$ used by the NRCS test kit Draeger tubes to be comparable. The reported values show similar trends between the soil test kit and standard method. The standard method shows higher values for WV2 and WV32 compared to the NRCS test kit method, however they are not significantly different. Site WV11 exhibited a significantly lower respiration by both methods compared to the other sites (Table 8). This site also reportedly had the lowest $\mathrm{pH}$ and $\mathrm{EC}$ values compared to the other three sites. It is possible that the lower $\mathrm{pH}$ was limiting the microbial activity in the soil (Fierer and Jackson, 2006), therefore resulting in lower respiration values.

The values presented for WV11 are considered "ideal soil activity" (Woods End Research, 1997) and are comparable to those reported by Doran et al. (1997) in a silty clay loam soil, however the results reported for the other three sites are higher than those in the literature. Results reported by Liebig et al. (1996) in conventional agricultural areas are similar to those found for WV2, WV16, and WV32 with ranges of $40.1 \mathrm{lb} \mathrm{CO} 2-\mathrm{C} \mathrm{ac}^{-1}$ day $^{-1}$ to $58.9 \mathrm{lb} \mathrm{CO} 2-\mathrm{C}$

$\mathrm{ac}^{-1}$ day ${ }^{-1}$. Stroo and Jencks (1982) found that mine soils reclaimed with grass-legume vegetation had higher respiration rates. 
Table 8. Differences in respiration obtained with standard and NRCS methods between sites.

\begin{tabular}{ccc} 
Site & $\begin{array}{c}\text { Soil Test Kit } \\
\text { Respiration }\end{array}$ & $\begin{array}{c}\text { Standard } \\
\text { Respiration }\end{array}$ \\
\hline WV2 & \multicolumn{2}{c}{$1 \mathrm{~b} \mathrm{CO}_{2}-\mathrm{C} \mathrm{ac}^{-1} \mathrm{day}^{-1}$} \\
\hline WV11 & $41.9 \pm 12.3 \mathrm{a}$ & $62.1 \pm 39.0 \mathrm{a}$ \\
WV16 & $25.9 \pm 6.1 \mathrm{~b}$ & $22.4 \pm 14.5 \mathrm{~b}$ \\
$\mathbf{W V 3 2}$ & $48.4 \pm 18.5 \mathrm{a}$ & $48.5 \pm 37.8 \mathrm{ab}$ \\
& $45.4 \pm 19.6 \mathrm{a}$ & $69.5 \pm 41.3 \mathrm{a}$
\end{tabular}

Note: Different letters in the columns indicate significant differences between sites within method at an $\alpha$ level of 0.10 .

As reported for previous soil health variables measured by the NRCS Soil Quality Test Kit and the standard laboratory methods, the mean separation for the standard lab measurements is more sensitive in separating the variable behavior by site.

\section{Experiment II: Time Since Reclamation and Soil Health}

\section{Physical Properties}

\section{Coarse Fragments and Fines}

Coarse and fine fragments in fifty (50) sampling points per site were measured across three sites by percent weight. Coarse fragments were particles $>2 \mathrm{~mm}$, whereas fines were $<2 \mathrm{~mm}$. Table 9 shows the average percent of coarse and fine particles and significant differences across the three sites. Site WV11 has significantly less coarse fragments (8\%), and significantly more fine particles (92\%) compared to WV2 and WV16 (Table 9). The coarse fragments percentage is significantly lower than the values reported in the literature of up to $70 \%$ coarse fraction (Ciolkosz et al., 1985; Thurman and Sencindiver, 1986; Roberts, et al., 1988; Hearing et al., 
2004). The lower amount of coarse fragment fraction may be due to the reclamation methods and the addition of topsoil or topsoil substitute on these sites. Bussler et al. (1984) showed reclaimed mine soils in Indiana to have an average of $2.2 \%$ coarse fragments in the topsoil material from 0 $29 \mathrm{~cm}$. The NRCS soil profile descriptions conducted during this study also support the findings of low coarse fragments at all sites (Appendix A, Fig. A1-A4).

Table 9. Differences in coarse fragments and fine particles (\% by weight) obtained with standard methods between sites.

Site

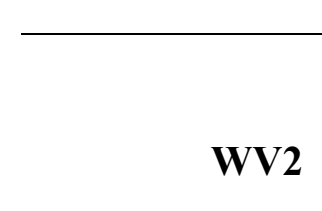

WV11

WV16
Coarse Fragments

Fines

Note: Different letters in the columns indicate significant differences between sites within method at an $\alpha$ level of 0.10 .

\section{Particle Size Distribution (Texture)}

In fifty (50) sampling points per site, particle size distribution (sand, silt, clay) at 0-15 cm depth was analyzed across the three sites. Table 10 presents the textural class for each site, and the observed differences in average sand, silt, and clay. Site WV2, the youngest site, was a silty clay loam soil, with an average of $198 \mathrm{mg} \mathrm{kg}^{-1}$ of sand, $522 \mathrm{mg} \mathrm{kg}^{1}$ of silt, and $281 \mathrm{mg} \mathrm{kg}^{1}$ of clay, which were significantly different to their corresponding particle sizes in WV11 and WV16. Site WV2 had significantly lower sand, and significantly higher silt and clay compared to the two older sites. Site WV16, clay loam, had significantly more sand (284 $\left.\mathrm{mg} \mathrm{kg}^{1}\right)$ and significantly less silt $\left(466 \mathrm{mg} \mathrm{kg}^{1}\right)$ and clay $\left(250 \mathrm{mg} \mathrm{kg}^{1}\right)$. These differences may be due to differences in dominant and mixed parent material of sandstone and shale, and possible surface 
erosion processes that occurred since reclamation. According to Roberts et al. (1988), particle distribution in young mine soils is strongly correlated to the parent material. According to Bussler et al. (1984), mine soils ranged from silt loam to clay loam textures, with more silt and clay particles than sand, which is similar to the findings at these three sites.

Table 10. Differences in texture $\left(\mathrm{mg} \mathrm{kg}^{-1}\right)$ obtained with standard methods between sites.

\begin{tabular}{ccccc} 
Site & Textural Class & Sand & Silt & Clay \\
\hline WV2 & Silty Clay Loam & $198 \mathrm{c}$ & $522 \mathrm{a}$ & $281 \mathrm{a}$ \\
WV11 & Clay Loam & $257 \mathrm{~b}$ & $480 \mathrm{~b}$ & $263 \mathrm{~b}$ \\
WV16 & Clay Loam & $284 \mathrm{a}$ & $466 \mathrm{c}$ & $250 \mathrm{c}$ \\
\hline
\end{tabular}

Note: Different letters in the columns indicate significant differences between sites within method at an $\alpha$ level of 0.10 .

\section{Bulk Density (BD)}

Surface $0-15 \mathrm{~cm}$ depth uncorrected BD and corrected BD was measured in fifty (50) sampling points per site using the excavation method. Table 11 indicates that uncorrected $\mathrm{BD}$ values are higher than the corrected $\mathrm{BD}$ for all sites, which was expected due to the inclusion ofrock fragments in the uncorrected BD. Site WV2 had significantly higher uncorrected and corrected BD values of $1.58 \pm 0.13 \mathrm{Mg} \mathrm{m}^{-3}$ and $1.51 \pm 0.15 \mathrm{Mg} \mathrm{m}^{-3}$, respectively. Site WV16 had a significantly lower corrected BD of $1.46 \pm 0.12 \mathrm{Mg} \mathrm{m}^{-3}$. In young soils, time since reclamation decreases $\mathrm{BD}$ due to an increase of organic matter in time (Twum and Nii-Annang, 2015; Bi et al., 2014). These BD values are similar to those stated in the literature of Bendfeldt et al. (2001), however were lower compared to the results of Thurman and Sencindiver (1986) and Mukhopadhyay et al. (2016). 
Table 11. Differences in $0-15 \mathrm{~cm}$ uncorrected and rock corrected soil bulk density $\left(\mathrm{Mg} \mathrm{m}^{-3}\right)$.

\begin{tabular}{ccc} 
Site & Uncorrected BD & Corrected BD \\
\hline WV2 & $1.58 \pm 0.13 \mathrm{a}$ & $\mathrm{Mg} \mathrm{m}^{-3}$ \\
WV11 & $1.53 \pm 0.16 \mathrm{~b}$ & $1.51 \pm 0.15 \mathrm{a}$ \\
WV16 & $1.54 \pm 0.13 \mathrm{ab}$ & $1.47 \pm 0.17 \mathrm{ab}$ \\
& & $1.46 \pm 0.12 \mathrm{~b}$ \\
\hline
\end{tabular}

Note: Different letters in the columns indicate significant differences between sites within method.

\section{Dry Aggregate Stability}

Surface $0-15 \mathrm{~cm}$ depth dry aggregate stability (DA) was characterized in fifty (50) sampling points per site by using the mean weight diameter (MWD). Table 12 presents the average DA MWD and significant differences from the three sites. Site WV2 had significantly greater DA stability compared to WV11 and WV16 with a MWD of 36.1 15 5.2. Site WV16 had a significantly lower MWD of 31.1 \pm 5.1 compared to WV2, however it was not significantly lower than site WV11. This may be due to the fact that the dry aggregates in younger mine soils are more likely influenced by compaction, rather than that of soil aggregate formation. Dry aggregation has been associated with the presence of compaction forces related to land use and soil type (Ćirić et al., 2012). Higher sand content such as the observed in WV16 has been related to lower DA stability, and higher clay content would be related to higher DA stability. These findings may explain the results observed in Table 10 . Ćirić et al. (2012) also indicated that larger DA-MWD were undesirable and these aggregate sizes are describing the younger sites. 
Table 12. Differences in 0-15 $\mathrm{cm}$ dry aggregate stability (MWD).

\begin{tabular}{ccc} 
Site & Dry Aggregate MWD & Wet Aggregate MWD \\
\hline WV2 & $36.1 \pm 5.2 \mathrm{a}$ & $\mathrm{mm}$ \\
$\mathbf{W V 1 1}$ & $32.9 \pm 7.1 \mathrm{~b}$ & $5.7 \pm 0.3 \mathrm{c}$ \\
$\mathbf{W V 1 6}$ & $31.1 \pm 5.1 \mathrm{~b}$ & $5.8 \pm 0.4 \mathrm{~b}$ \\
\end{tabular}

Note: Different letters in the columns indicate significant differences between sites within method at an $\alpha$ level of 0.10 .

\section{Wet Aggregate Stability (WA)}

Surface $0-15 \mathrm{~cm}$ depth wet aggregate (WA) stability was also characterized in fifty (50) sampling points per site, using MWD across all three sites. Table 12 shows that the oldest site Surface $0-15 \mathrm{~cm}$ depth wet aggregate (WA) stability was also characterized in fifty (50) sampling points per site, using MWD across all three sites. Table 12 shows that the oldest site, WV16, had significantly greater WA stability (MWD of $6.1 \pm 0.1$ ), than the youngest site, WV2, (MWD of 5.7 \pm 0.3 ). These results support the findings of Thomas et al. (2000) and Wick et al. (2009) of water-stable aggregates increasing with time since reclamation. Ussiri et al. 2006, found similar MWD values in reclaimed mine soils of Ohio that ranged from 0.32 to $5.19 \mathrm{~mm}$, with the greatest MWD in the soil surface layers of 0-5 $\mathrm{cm}$ and $5-10 \mathrm{~cm}$. The results indicate that even though DA stability decreased with time since reclamation, wet aggregate stability increased with time. This indicates a higher structural integrity of the aggregates under wetting situations as mine soils develop, which would be expected due to the increase in biological activity of plants and microbial 
populations as measured in Experiment I.

\section{Chemical Properties}

\section{pH}

Table 13 shows the average $\mathrm{pH}$ of fifty (50) sampling points per site, and significant differences between the sites. Site WV11 had a significantly lower $\mathrm{pH}$ of $5.8 \pm 0.4$ compared to WV2 and WV16. These differences may be due to differences in dominant and mixed parent material of sandstone and shale (Roberts et al., 1988; Hearing et al., 1993). All three sites showed $\mathrm{pH}$ values between 5.5-6.5, similar to those reported by other researchers (Thomas et al., 2000; Hearing et al., 2004).

Table 13. Differences in $0-15 \mathrm{~cm}$ pH between sites at an $\alpha$ level of 0.10 .

\begin{tabular}{cc} 
Site & pH \\
\hline WV2 & $6.1 \pm 0.6 \mathrm{a}$ \\
WV11 & $5.8 \pm 0.4 \mathrm{~b}$ \\
WV16 & $6.2 \pm 0.8 \mathrm{a}$
\end{tabular}

Note: Different letters in the columns indicate significant differences between sites.

\section{Available Nutrients}

Plant available nutrients were measured using a Mehlich III extraction in soil samples obtained from fifty (50) sampling points per site at a depth of $0-15 \mathrm{~cm}$. Table 14 shows the average amount of nutrients and significant differences between the sites. Site WV16 had significantly more $\mathrm{Al}$ and $\mathrm{Na}$ than the two younger sites. Whereas site WV2 had significantly more $\mathrm{Mg}, \mathrm{P}$, and $\mathrm{Zn}$ than the two older sites. The measurements of $\mathrm{K}, \mathrm{Ca}, \mathrm{Mg}$, and $\mathrm{Zn}$ were comparable to those found in an agricultural soil at the organic farm in Monongalia Co., WV (Pena-Yewtukhiw et al., 2017). The measured $\mathrm{P}$ in this study was found to be lower than the $\mathrm{P}$ in 
the literature in both the agricultural system and mine soils (Roberts et al., 1988; Bendfeldt et al., 2001; Pena-Yewtukhiw et al., 2017). The measured K was similar to those found by Roberts et al. (1988) and Bendfeldt et al. (2001). However, the Ca and Al were higher, while the Fe and $\mathrm{Na}$ were lower compared to the literature in mine soils (Roberts et al., 1988; Bussler et al., 1984;

Bendfeldt et al., 2001).

Table 14. Differences in Mehlich III extracted bioavailable nutrients (mg kg-1) between sites at an $\alpha$ level of 0.10 .

\begin{tabular}{ccccccccc} 
Site & Al & Ca & Fe & K & Mg & Na & P & Zn \\
\hline & & \multicolumn{7}{c}{$\mathrm{mg} \mathrm{kg}^{-1}$} \\
WV2 & $490 \mathrm{~b}$ & $1575 \mathrm{a}$ & $87.6 \mathrm{a}$ & $104 \mathrm{a}$ & $202 \mathrm{a}$ & $71.3 \mathrm{~b}$ & $8.89 \mathrm{a}$ & $1.97 \mathrm{a}$ \\
WV11 & $499 \mathrm{~b}$ & $983 \mathrm{~b}$ & $59.5 \mathrm{~b}$ & $105 \mathrm{a}$ & $120 \mathrm{c}$ & $70.6 \mathrm{~b}$ & $4.31 \mathrm{~b}$ & $1.06 \mathrm{c}$ \\
WV16 & $541 \mathrm{a}$ & $1753 \mathrm{a}$ & $83.5 \mathrm{a}$ & $97.8 \mathrm{a}$ & $135 \mathrm{~b}$ & $79.4 \mathrm{a}$ & $5.31 \mathrm{~b}$ & $1.64 \mathrm{~b}$
\end{tabular}

Note: Different letters in the columns indicate significant differences between sites.

Initial chemical concentration of salts and bioavailable nutrients in a mine soil will be related to the mineral and organic concentration of the substrate used during reclamation. However, it is expected that over time, these elements may become more similar to natural soils (natural benchmarks) (Howell et al., 2016).

\section{Biological Properties}

\section{Soil Organic Matter}

Soil organic matter (SOM) was measured using LOI from 0 to $15 \mathrm{~cm}$ across all three sites. Table 15 indicates that site WV11 exhibited significantly less SOM of $42.2 \pm 6.1 \mathrm{~g} \mathrm{~kg}^{-1}$ compared to WV2 and WV16. These results do not support the findings of Pedersen et al. (1980) or Bussler et al. (1984) of relatively low SOM in mine soils. These results may be due to the amount of root mass at the soil surface in the studied mine sites. However, the 
results support findings from researchers like Bendfeldt et al. (2001) and Chaudhuri et al. (2011), whereas time increases since reclamation, organic matter increases.

Table 15. Differences in soil organic matter $\left(\mathrm{g} \mathrm{kg}^{-1}\right)$ obtained with standard methods between sites.

\begin{tabular}{cc} 
Site & $\begin{array}{c}\text { SOM } \\
\left(\mathrm{g} \mathrm{kg}^{-1}\right)\end{array}$ \\
\hline WV2 & $52.8 \pm 10.5 \mathrm{a}$ \\
WV11 & $42.2 \pm 6.1 \mathrm{~b}$ \\
WV16 & $55.1 \pm 9.5 \mathrm{a}$
\end{tabular}

Note: Different letters in the columns indicate significant differences between sites at an $\alpha$ level of 0.10 .

\section{Vegetation Survey}

Vegetation surveys recording plant classification percentage on each site in 2017 and 2018 are presented in Table 16. At the start of this study in 2017, WV2 had significantly more forbs than WV11 and WV16, whereas WV11 had significantly more grasses (Figure 14). These results may be related to the higher bulk density observed in WV2 limiting the growth of the grasses and legumes, as well as the concept of pioneer species being the first to colonize in a disturbed area (Groninger et al., 2007). Sites WV11 and WV16 had significantly more time to establish a denser coverage of the seeded grasses and legumes compared to WV2. In 2018, WV11 and WV16 had significantly more legumes than WV2, and all sites had between $45-50 \%$ grasses (Figure 15). The increase in grasses in WV2 between 2017 and 2018 can be contributed to having time to establish vegetation as a young site.

In mine soil, and soils in general (Moujahid et al., 2017), there is a tight relationship between soil and vegetation. Soil type has been known to cooperatively shape the pattern of plant species (Garcia-Palacio et al., 2012). Soil pH, among other factors, controls microbial 
communities which result in different soil types housing microbial populations (Fierer and Jackson, 2006). Plant species have been known to correlate to these specific microbial populations due to their root exudates (Berg and Smalla, 2009). Tilman (1984) described how spatial variability of nutrients may be a cause of heterogeneity in early successional vegetation.

Bi et al. (2014) described vegetation type as having significant effects on bulk density after just one year after reclamation, and reported that a higher diversity of plants improved water conservation and vegetation recovery in mine soils. Bendfeldt et al. (2001) also recognized the overriding effect of vegetation on the soil recovery process in mine soil reclamation.

An interesting observation is that in an average precipitation year, legume presence is not a good index for mine soil age. However, in a wet year, characterized by high moisture content, the development of legumes is limited in the high-density soil (the youngest soil). Grasses behave the opposite as legumes, which may also be explained by moisture conditions.

Table 16. Differences in vegetation diversity obtained with standard methods between sites.

\begin{tabular}{lccccccc} 
Site & Legumes & Forbs & Grass & & Legumes & Forbs & Grass \\
\hline & & & & & & & \\
\cline { 3 - 5 } & & & & & & & \\
WV2 & $36.3 \mathrm{a}$ & $36.7 \mathrm{a}$ & $16.7 \mathrm{c}$ & & $13.6 \mathrm{~b}$ & $35.5 \mathrm{a}$ & $45.1 \mathrm{a}$ \\
\cline { 2 - 7 } WV11 & $34.3 \mathrm{a}$ & $10.8 \mathrm{c}$ & $50.1 \mathrm{a}$ & & $29.1 \mathrm{a}$ & $14.5 \mathrm{~b}$ & $49.9 \mathrm{a}$ \\
WV16 & $37.2 \mathrm{a}$ & $18.6 \mathrm{~b}$ & $30.6 \mathrm{~b}$ & & $24.1 \mathrm{a}$ & $18.0 \mathrm{~b}$ & $46.7 \mathrm{a}$
\end{tabular}

Note: Different letters in the columns indicate significant differences between sites within method at an $\alpha$ level of 0.10 . 


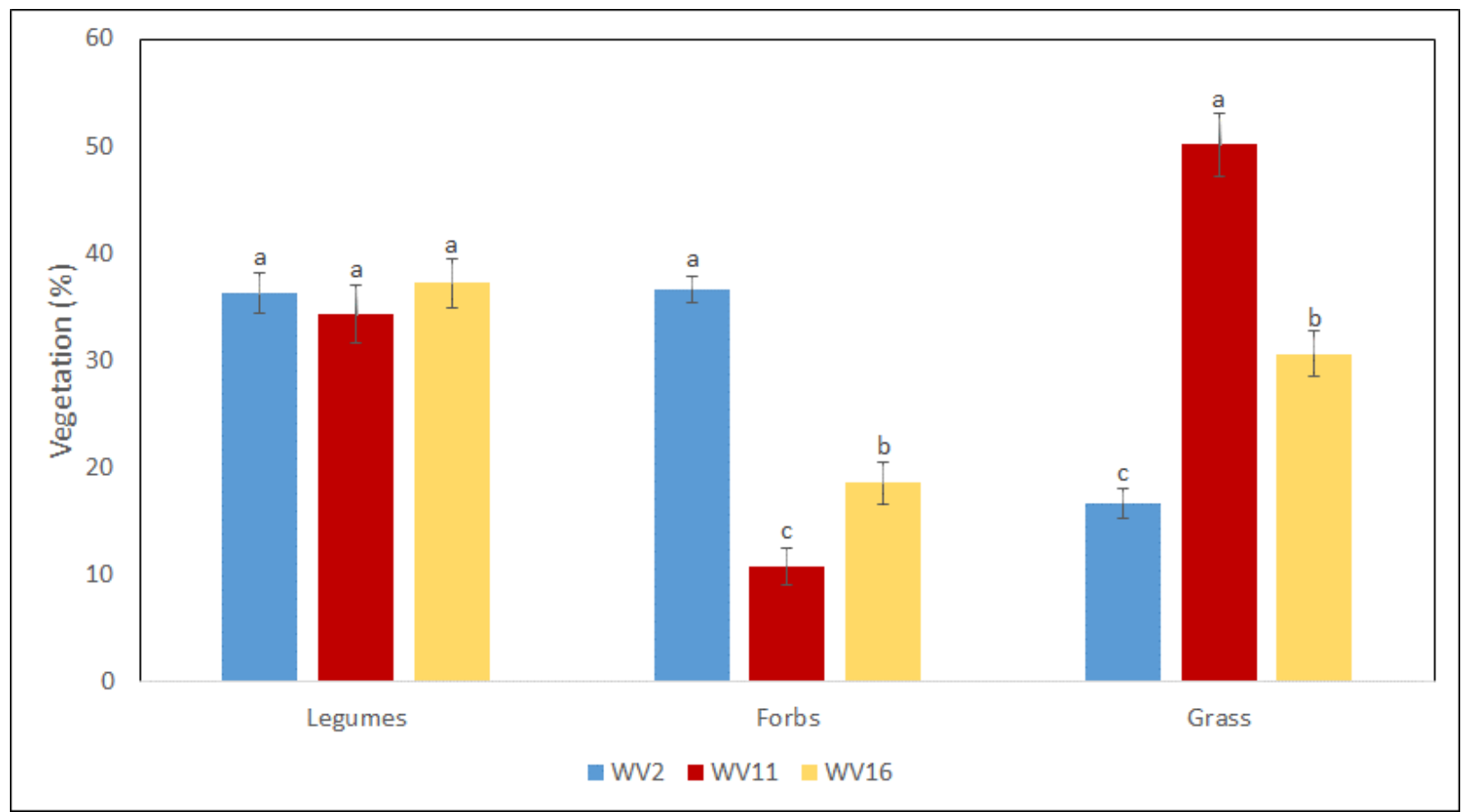

Figure 14. Comparison of 2017 plant classification diversity by site.

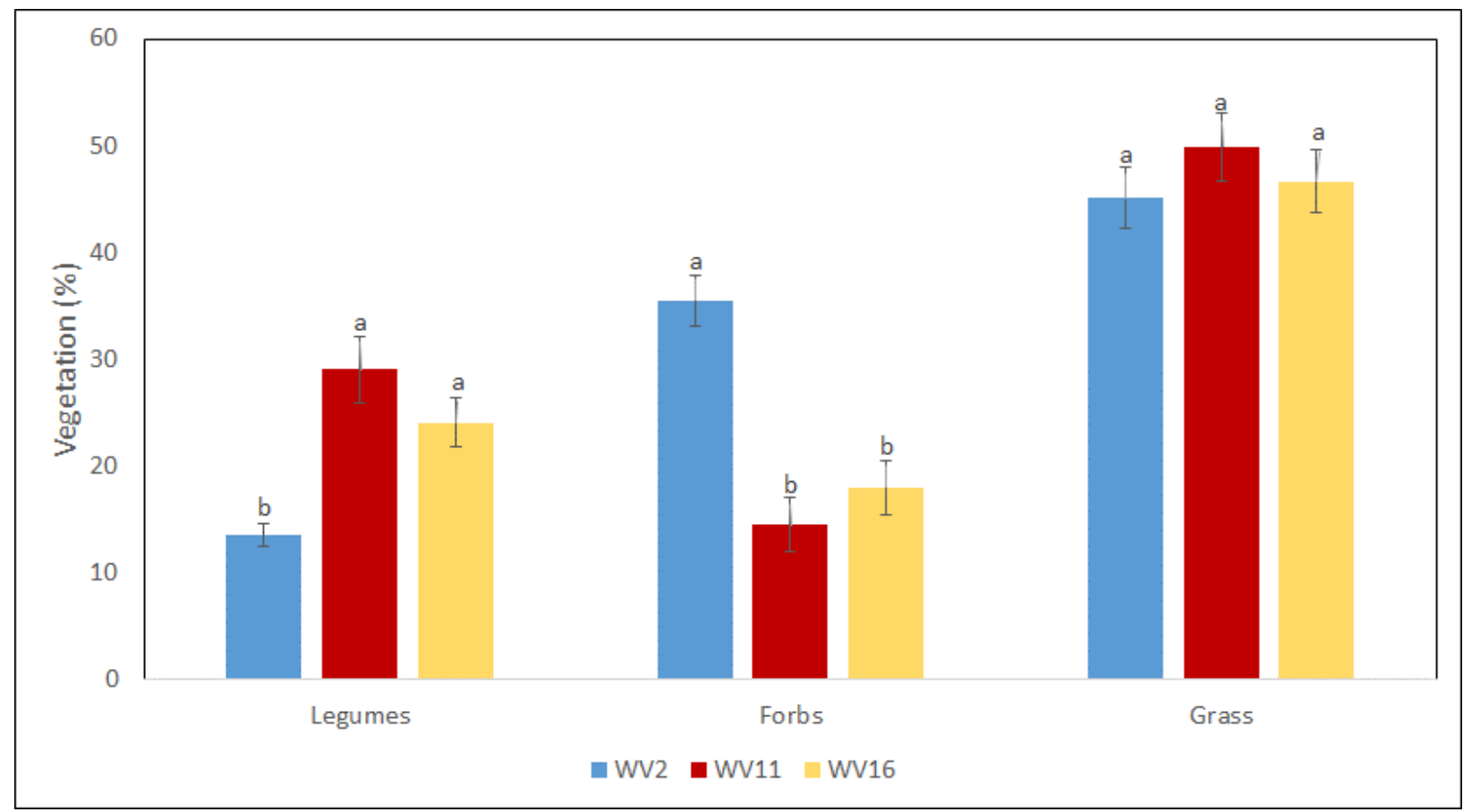

Figure 15. Comparison of 2018 plant classification diversity by site. 


\section{Experiment III: Time Since Reclamation and Response to Management}

\section{Physical Properties}

\section{Coarse Fragments and Fines, and Particle Size Distribution (Texture) characterization}

Coarse and fine fragments in eighteen (18) sampling points per site were measured across three sites by percent weight. Coarse fragments were considered all particles $>2 \mathrm{~mm}$ (Schoeneberger et al., 2012), with fines being $<2 \mathrm{~mm}$. The percentage of coarse fragments varied between $6.63 \pm 4.37$ and $7.86 \pm 3.87$ percent, and the percentage of fines between $92.1 \pm 3.87$ and $93.4 \pm 4.37$ (Table 17). No statistically significant difference $(\mathrm{p}=0.3573)$ was observed for coarse fragments $(p=0.3573)$ and for fine fragments $(p=0.3573)$ between sites (Table 17). As stated in the previous section, these values are significantly different from those reported in the literature (Ciolkosz et al., 1985; Thurman and Sencindiver, 1986; Roberts, et al., 1988; Hearing et al., 2004), except for those stated by Bussler et al. (1984).

Across all study sites, there was no overall effect of treatment, block, site, or year on coarse fragments or fine particles (Table 17). However, there was an interaction between treatment and site for both coarse fragments and fine particles (Table 17). No fertilizer application on WV2 had the highest coarse fragments $(9 \pm 3 \%)$ and lowest fine particles $(91 \pm 3 \%)$, whereas no fertilizer on WV11 had the lowest coarse fragments $(5 \pm 4 \%)$ and highest fine particles $(95 \pm 4 \%)$. This result may be an artifact caused by the high variability of soils observed in the younger sites WV2 and VW11. No cause effect relationship between fertilizer application and particle size was expected.

Regarding to soil texture, site WV2 had significantly lower sand content (182 $\left.\pm 27 \mathrm{mg} \mathrm{kg}^{-1}\right)$, and significantly higher silt $\left(533 \pm 60 \mathrm{mg} \mathrm{kg}^{-1}\right)$ and clay $\left(285 \pm 40 \mathrm{mg} \mathrm{kg}^{-1}\right)$ contents compared to the other sites (Table 17). These results are similar to those found and discussed in the previous section. 
As expected, there was no effect of treatment or year on particle size distribution.

However, due to spatial variability, there was an interaction of block and site on sand, silt, and clay measurements (Appendix C, Table C1). This supports the selection of the block experimental design used in this study. The effect of block and site on these measurements may be due to the addition of topsoil or topsoil substitute and mixed dominant parent material described previously.

Table 17. Effect of site and year on coarse and fine fragments, and texture (sand, silt and clay).

\begin{tabular}{|c|c|c|c|c|c|}
\hline & $\begin{array}{c}\text { Coarse } \\
\text { Fragments }\end{array}$ & Fines & Sand & $\begin{array}{l}\text { Silt } \\
\mathrm{mg} \mathrm{kg}^{-1}\end{array}$ & Clay \\
\hline \multicolumn{6}{|l|}{ Site } \\
\hline WV2 & $7.86 \pm 3.87 \mathrm{a}$ & $92.1 \pm 3.87 \mathrm{a}$ & $182 \pm 27^{\mathrm{c}}$ & $533 \pm 60^{\mathrm{a}}$ & $285 \pm 40^{\mathrm{a}}$ \\
\hline WV11 & $6.63 \pm 4.37 \mathrm{a}$ & $93.4 \pm 4.37 \mathrm{a}$ & $251 \pm 29^{b}$ & $490 \pm 15^{b}$ & $259 \pm 17^{b}$ \\
\hline WV16 & $7.32 \pm 3.71 \mathrm{a}$ & $92.7 \pm 3.71 \mathrm{a}$ & $272 \pm 53^{\mathrm{a}}$ & $465 \pm 35^{c}$ & $262 \pm 32^{b}$ \\
\hline \multirow[t]{2}{*}{ Grand Mean } & $7.27 \pm 4.0$ & $92.7 \pm 4.0$ & $235 \pm 54$ & $496 \pm 49$ & $269 \pm 33$ \\
\hline & \multicolumn{5}{|c|}{$\operatorname{Pr}>F$} \\
\hline Site & 0.3573 & 0.3573 & $<0.0001$ & $<0.0001$ & 0.0002 \\
\hline Year & 0.1097 & 0.1097 & 0.6484 & 0.9001 & 0.6650 \\
\hline
\end{tabular}

Same letters in the same columns indicate no statistically significant differences (Least Squares Means) at $\mathrm{p}<0.10$.

\section{Bulk Density (BD)}

Uncorrected BD and corrected BD was measured in eighteen (18) sampling points per site using the excavation method to a depth of $0-15 \mathrm{~cm}$. Table 18 presents the comparison between the corrected BD sites for each sampling year. Regardless of fertilizer treatment, corrected BD 
$\left(1.62 \pm 0.13 \mathrm{Mg} \mathrm{m}^{-3}\right)$ was significantly higher for WV16 in 2017 as compared to WV2 and WV11, however in 2018 site WV2 had significantly higher corrected BD $\left(1.58 \pm 0.12 \mathrm{Mg}^{-3}\right)$ (Table 18). The contrasting results between years may be due to variability of topsoil and compaction across the sites, and small sampling size. The results observed in 2018 are similar to the corrected BD reported in Experiment II using a larger sampling size of fifty points.

Table 18. Effect of site on rock corrected bulk density $\left(\mathrm{Mg} \mathrm{m}^{-3}\right)$.

\begin{tabular}{|c|c|c|c|c|}
\hline \multirow[b]{4}{*}{ WV2 } & \multicolumn{4}{|c|}{ Corrected BD $\left(\mathrm{Mg} \mathrm{m}^{-3}\right)$} \\
\hline & 2017 & 2018 & 2017 & 2018 \\
\hline & \multicolumn{2}{|c|}{ No Fertilizer } & \multicolumn{2}{|c|}{ Fertilizer } \\
\hline & $\xi 1.45 \pm 0.11 \mathrm{~b}$ & $1.55 \pm 0.14 \mathrm{a}$ & $\xi 1.47 \pm 0.11 \mathrm{~b}$ & $1.60 \pm 0.09 \mathrm{a}$ \\
\hline WV11 & $1.49 \pm 0.13 \mathrm{~b}$ & $1.45 \pm 0.07 \mathrm{~b}$ & $\xi 1.55 \pm 0.15 \mathrm{~b}$ & $1.45 \pm 0.15 b$ \\
\hline WV16 & $\xi 1.60 \pm 0.13 \mathrm{a}$ & $1.46 \pm 0.07 \mathrm{~b}$ & $\xi 1.64 \pm 0.14 \mathrm{a}$ & $1.43 \pm 0.15 b$ \\
\hline
\end{tabular}

Note: Different letters in the column indicate significant differences between sites at $\mathrm{P}<0.10$. $\xi$ indicates significant differences between years for a given treatment for the same site.

Treatment did not significantly affect BD values (Table 18), however when no fertilizer was applied, an increase in WV2 and a decrease for WV16 were observed (Table 18) between 20172018, and no changes in BD for WV11 were measured. Although, when fertilizer was applied, both WV11 and WV16 experienced reduction of BD between 2017-2018, and WV2 showed a significant increase in $\mathrm{BD}$. The increase in $\mathrm{BD}$ measured in site WV2 affected the main effect of year. On average, the corrected BD in $2017(1.53 \pm 0.14)$ was significantly higher compared to $2018(1.49 \pm 0.13)$ (Table 19). Changes in vegetation growth, especially grasses, may have affected $\mathrm{BD}$, decreasing its value in the older sites. However, although significant, the small difference may not produce evident changes in other soil processes. Bulk density exhibited an interaction Treatment*Site*Year. This interaction was explained by BD behavior in the younger site being opposite to the behavior in both the older sites. Weather and vegetation development 
have been discussed as affecting soil properties such as aggregation and bulk density. An et al. (2013) reported different BD values for different revegetation patterns at different soil depths, as time increased since revegetation, lower bulk densities were observed, especially at the surface 0-20 cm. This finding supports our data.

\section{Dry Aggregate Stability}

Surface $0-15 \mathrm{~cm}$ depth dry aggregate stability (DA) was characterized in eighteen (18) sampling points per site using the mean weight diameter (MWD). There was an overall increase in DA-MWD between 2017 and 2018 seen across all three sites (Table 20), which supports the hypothesis of aggregation increasing with time due to the addition and establishment of vegetation and organic matter. However, the oldest site, WV16, had significantly lower DAMWD in 2017 and $2018(25.7 \pm 7.2 \mathrm{~mm} ; 31.7 \pm 4.7 \mathrm{~mm})$, and WV11 had the highest DA-MWD $(34.6 \pm 4.2 \mathrm{~mm} ; 38.4 \pm 4.5 \mathrm{~mm})$. 
Table 19. Effect of fertilizer treatment, site and year on corrected BD, dry aggregate (DA) and wet aggregate (WA) mean weight diameter (MWD).

\begin{tabular}{|c|c|c|c|c|}
\hline & & $\begin{array}{c}\mathrm{BD} \\
\mathrm{Mg} \mathrm{m}^{-3}\end{array}$ & Dry MWD & Wet MWD \\
\hline \multicolumn{5}{|l|}{ Treatment } \\
\hline & No Fertilizer & $1.50 \pm 0.12 \mathrm{a}^{*}$ & $32.2 \pm 5.63 \mathrm{a}$ & $5.98 \pm 0.26 \mathrm{a}$ \\
\hline & Fertilizer & $1.52 \pm 0.15 \mathrm{a}$ & $33.3 \pm 6.28 \mathrm{a}$ & $5.98 \pm 0.25 \mathrm{a}$ \\
\hline \multicolumn{5}{|l|}{ Site } \\
\hline & WV2 & $1.52 \pm 0.13 \mathrm{ab}$ & $33.0 \pm 4.9 \mathrm{~b}$ & $5.91 \pm 0.25$ \\
\hline & WV11 & $1.49 \pm 0.13 \mathrm{~b}$ & $36.5 \pm 4.7 \mathrm{a}$ & $5.89 \pm 0.28$ \\
\hline & WV16 & $1.54 \pm 0.15 \mathrm{a}$ & $28.7 \pm 6.7 \mathrm{c}$ & $6.13 \pm 0.13$ \\
\hline
\end{tabular}

Year

$\begin{array}{llll}2017 & 1.53 \pm 0.14 \mathrm{a} & 30.6 \pm 6.9 \mathrm{~b} & 5.95 \pm 0.25 \mathrm{a} \\ 2018 & 1.49 \pm 0.13 \mathrm{~b} & 34.8 \pm 5.0 \mathrm{a} & 6.00 \pm 0.26 \mathrm{a}\end{array}$

Treatment*Site*Year

$\begin{array}{rccc}\text { No Fertilizer*WV2*2017 } & 1.45 \pm 0.11 & 28.8 \pm 3.09 & 5.86 \pm 0.28 \\ \text { No Fertilizer*WV2*2018 } & 1.55 \pm 0.15 & 34.89 \pm 2.77 & 5.94 \pm 0.31 \\ \text { No Fertilizer*WV11*2017 } & 1.49 \pm 0.13 & 35.9 \pm 5.18 & 5.79 \pm 3.64 \\ \text { No Fertilizer*WV11*2018 } & 1.45 \pm 0.07 & 37.3 \pm 3.86 & 6.04 \pm 0.17 \\ \text { No Fertilizer*WV16*2017 } & 1.60 \pm 0.13 & 26.1 \pm 6.36 & 6.11 \pm 0.8 \\ \text { No Fertilizer*WV16*2018 } & 1.47 \pm 0.07 & 30.3 \pm 5.02 & 6.12 \pm 0.17 \\ \text { Fertilizer*WV2*2017 } & 1.47 \pm 0.11 & 34.3 \pm 6.87 & 5.92 \pm 0.19 \\ \text { Fertilizer*WV2*2018 } & 1.60 \pm 0.09 & 33.8 \pm 3.87 & 5.91 \pm 0.25 \\ \text { Fertilizer*WV11*2017 } & 1.50 \pm 0.15 & 33.4 \pm 2.74 & 5.86 \pm 0.22 \\ \text { Fertilizer*WV11*2018 } & 1.45 \pm 0.15 & 39.5 \pm 5.10 & 5.86 \pm 0.34 \\ \text { Fertilizer*WV16*2017 } & 1.64 \pm 0.14 & 25.3 \pm 8.25 & 6.13 \pm 0.10 \\ \text { Fertilizer*WV16*2018 } & 1.44 \pm 0.15 & 33.2 \pm 4.23 & 6.14 \pm 0.17 \\ \text { Mean } & 1.51 \pm 0.14 & 32.7 \pm 6.34 & 5.98 \pm 0.25\end{array}$




$\begin{array}{lccc} & & & \\ \text { Block } & 0.0365 & 0.6189 & 0.8159 \\ \text { Treatment } & 0.3799 & 0.2988 & 0.9360 \\ \text { Site } & 0.2194 & <0.0001 & <0.0001 \\ \text { Year } & 0.0744 & <0.0001 & 0.2460 \\ \text { Treatment*Site } & 0.8558 & 0.6426 & 0.6726 \\ \text { Treatment*Year } & 0.5010 & 0.7727 & 0.1923 \\ \text { Treatment*Site*Year } & 0.0001 & 0.0763 & 0.6714\end{array}$

Same letters in the same columns indicate no statistically significant differences (Least Squares Means) at $\mathrm{p}<0.10$.

Dry aggregate (DA) stability of WV2 was not significantly different $(31.6 \pm 5.9 \mathrm{~mm})$ than WV11 in 2017 , however was significantly lower $(34.3 \pm 3.3 \mathrm{~mm})$ than WV11 and significantly higher than WV16 in 2018. These results are similar to those discussed in Experiment II.

Table 20. Effect of year and site on dry aggregate (DA) and wet aggregate (WA) stability (MWD) (mm).

\begin{tabular}{lcrrr}
\multicolumn{1}{r}{ Site } & DA & WA & DA & WA \\
\hline & \multicolumn{3}{c}{ MWD (mm) } \\
& \multicolumn{5}{c}{2017} \\
WV2 & $31.6 \pm 5.9 \mathrm{a}$ & $5.9 \pm 0.2 \mathrm{~b}$ & $34.3 \pm 3.3 \mathrm{~b}$ & $5.9 \pm 0.3 \mathrm{~b}$ \\
WV11 & $34.6 \pm 4.2 \mathrm{a}$ & $5.8 \pm 0.3 \mathrm{~b}$ & $38.4 \pm 4.5 \mathrm{a}$ & $6.0 \pm 0.3 \mathrm{~b}$ \\
WV16 & $25.7 \pm 7.2 \mathrm{~b}$ & $6.1 \pm 0.1 \mathrm{a}$ & $31.7 \pm 4.7 \mathrm{c}$ & $6.1 \pm 0.2 \mathrm{a}$ \\
\hline
\end{tabular}

Note: Different letters in the columns indicate significant differences between sites at $p<0.10$.

Table 19 presents the Analysis of Variance (ANOVA) for DA-MWD and WAMWD. There was a significant effect of year and site on DA-MWD and WA-MWD. The highest DA-MWD was reported for WV11 followed by WV2, and the lowest in WV16. Although the trend between sites was maintained in 2018, an increase between 2017 and 2018 was observed. The effect of higher precipitation in 2018 and plant growth increased 
the root effect (entanglement) on holding soil particles and creating larger aggregates. Dry aggregate - MWD exhibited a Treatment*Site*Year interaction, regardless of fertilization treatment WV11 and WV16 exhibited an increase in DA-MWD between 2017 and 2018, however WV2 increased DA-MWD in the non-fertilizer treatment and decreased in the fertilized treatment (Table 19). The youngest site had the lowest vegetation development, and fertilization treatment did not improve this condition (this will be discussed in the next sections).

\section{Wet Aggregate Stability}

The ANOVA analysis indicated there was only a site effect on WA-MWD (Table 19). The site effect can be related to the time since reclamation. Wet aggregate stability (WA-MWD) was significantly higher in the oldest site WV16 in $2017(6.1 \pm 0.1 \mathrm{~mm})$ and $2018(6.1 \pm 0.2 \mathrm{~mm})$, compared to the youngest site WV2 $(5.9 \pm 0.2 \mathrm{~mm} ; 5.9 \pm 0.3 \mathrm{~mm})$ and WV11 $(5.8 \pm 0.3 \mathrm{~mm}$; $6.0 \pm 0.3 \mathrm{~mm}$ (Table 20)). These results are similar to those reported and discussed in Experiment II. No statistically significant difference between the two younger sites or an effect of the fertilization treatment was observed. The higher wet aggregate stability in older sites could be related to an increase in pedogenic processes and higher biological activity. Higher aggregate stabilities have been observed with an increase of time under afforestation (An et al., 2013) or systems that have been transitioning into grasslands after disturbance (Pena-Yewtukhiw, et al., 2018). Wet aggregate stability has been related to vegetation (Devine et al., 2014). With more stable vegetation in time and less human intervention, such as that generated in mine soils after reclamation, the size of water-stable aggregates increases. Higher organic matter measured in the oldest side has also been related to increase wet aggregate stability. These results support the data obtained in this experiment. 


\section{Chemical Properties}

pH

Soil $\mathrm{pH}$, also called "soil reaction", is a soil property that explains nutrient availability and biological activity including plant populations (Fuji, 2014). The effect of time on soil pH was not significant (Table 21 and 22), and the only significant effects observed in the experiment were due to block, site and treatment (Table 22). Soil pH in WV11 (5.7 \pm 0.3$)$ was significantly lower in 2017 as compared to WV2 $(6.1 \pm 0.6)$ and WV16 $(6.1 \pm 0.8)$. However, there were no significant differences in $\mathrm{pH}$ across the three sites in 2018, or between treatments in 2017 and 2018 (Table 22). In general, the mine soils in the three sites could be considered suitable because the $\mathrm{pH}$ is higher than 5.5 and lower than 7.5 (USDA-NRCS).

Huggett (1998) discusses in his paper the influence of time and vegetation on soil $\mathrm{pH}$; he stated that $\mathrm{pH}$ decreased linearly for the first 2900 years, however, after this time, biological effects of plant communities have influenced the soil $\mathrm{pH}$ and its evolution. In natural unmanaged soils, as the soil is older in the chronosequence, the $\mathrm{pH}$ is expected to decrease with associated nutrient/fertility loss. However, in altered soils such as reclaimed mine soils, soil $\mathrm{pH}$ may be affected by the age and the vegetation characteristics used in the reclamation. In altered urban systems, younger reclaimed soils tend to have higher $\mathrm{pH}$ than older soils (Setälä et al., 2016).

This trend is similar to that observed in this study between the younger site WV2 and older site WV11, but since site WV16 was managed for several years, the $\mathrm{pH}$ may have been increased with years of liming. 
Table 21. Effect of site and year on $\mathrm{pH}$

\begin{tabular}{lcc}
\multicolumn{1}{c}{ Site } & $\mathbf{p H}$ & $\mathbf{p H}$ \\
\hline & 2017 & 2018 \\
\cline { 2 - 3 } WV2 & $6.1 \pm 0.6^{\mathrm{a}}$ & $5.9 \pm 0.4^{\mathrm{a}}$ \\
WV11 & $5.7 \pm 0.3^{\mathrm{b}}$ & $5.8 \pm 0.5^{\mathrm{a}}$ \\
WV16 & $6.1 \pm 0.8^{\mathrm{a}}$ & $6.0 \pm 0.9^{\mathrm{a}}$ \\
\hline
\end{tabular}

Note: Different letters in the columns indicate significant differences between sites within method at $\mathrm{p}<0.10$.

Table 22. Effect of fertilizer treatment, site and year on $\mathrm{pH}$ and soil organic matter (SOM in mg $\left.\mathrm{kg}^{-1}\right)$.

$\mathrm{pH} \quad \mathrm{SOM}$

$$
\mathrm{mg} \mathrm{kg}^{-1}
$$

\section{Treatment}

No Fertilizer

$$
5.82 \pm 0.61^{\mathrm{b}}
$$

$47.9 \pm 10.4^{\mathrm{a}}$

Fertilizer

$6.01 \pm 0.60^{\mathrm{a}}$

$48.2 \pm 11.3^{\mathrm{a}}$

Site

WV2

$$
5.97 \pm 0.52^{\mathrm{a}}
$$

$52.6 \pm 11.1^{\mathrm{a}}$

WV11

$$
5.74 \pm 0.37^{\mathrm{b}}
$$

$40.8 \pm 7.2^{b}$

WV16

$6.03 \pm 0.83^{\mathrm{a}}$

$50.7 \pm 9.9^{\mathrm{a}}$

Year

2017

$5.96 \pm 0.60^{\mathrm{a}}$

$42.3 \pm 8.3^{b}$

2018

$5.87 \pm 0.62^{\mathrm{a}}$

$53.7 \pm 10.1^{\mathrm{a}}$

Site*Year

$2017 *$ WV2

$6.06 \pm 0.58$

$43.7 \pm 4.19$ 


\begin{tabular}{lcc}
$2017 * \mathrm{WV} 11$ & $5.73 \pm 0.26$ & $36.0 \pm 4.33$ \\
$2017 * \mathrm{WV} 16$ & $6.10 \pm 0.78$ & $47.3 \pm 10.4$ \\
$2018 * \mathrm{WV} 2$ & $5.89 \pm 0.44$ & $61.5 \pm 8.32$ \\
$2018 * \mathrm{WV} 11$ & $5.75 \pm 0.45$ & $45.5 \pm 6.29$ \\
$2018 * \mathrm{WV} 16$ & $5.96 \pm 0.88$ & $54.1 \pm 8.43$ \\
Treatment*Site & & \\
No Fertilizer*WV2 & $5.88 \pm 0.36$ & $53.2 \pm 12.8$ \\
No Fertilizer*WV11 & $5.68 \pm 0.39$ & $42.5 \pm 6.2$ \\
No Fertilizer*WV16 & $5.91 \pm 0.91$ & $48.0 \pm 8.7$ \\
Fertilizer*WV2 & $6.07 \pm 0.63$ & $52.0 \pm 9.5$ \\
Fertilizer*WV11 & $5.81 \pm 0.34$ & $39.1 \pm 7.8$ \\
Fertilizer*WV16 & $6.15 \pm 0.74$ & $53.5 \pm 10.6$ \\
Grand Mean & $5.92 \pm 0.61$ & $48.0 \pm 10.8$ \\
& & \\
\hline Block & $-----------------P r>F----------------$ \\
Treatment & 0.0007 & 0.0473 \\
Site & 0.0953 & 0.8318 \\
Year & 0.0845 & $<0.0001$ \\
Site*Year & 0.3850 & $<0.0001$ \\
Site*Treatment & 0.9079 & $<0.0001$ \\
\hline
\end{tabular}

Same letters in the same columns indicate no statistically significant differences at $\mathrm{p}<0.10$. *Average \pm Standard Deviation

Regardless of time and site, treatment effect can be described as a decrease in $\mathrm{pH}$ when urea is applied (Table 22). No interactions between the factors were observed for $\mathrm{pH}$ (Table 22). The rate of $\mathrm{N}$ applied in this experiment was selected to not affect the soil chemical properties of the soil (not affecting soil health properties), but to obtain a response in plant growth if the "physical 
and chemical" soil health characteristics were appropriate. The increase in $\mathrm{pH}$ could be related to the increase in organic matter in the soil. Pena-Yewtukhiw et al. (2018) observed a comparable increase in $\mathrm{pH}$ related to organic matter or plant growth in a transitioning system.

\section{Soil Organic Matter (SOM)}

Soil organic matter (SOM) could be considered a physical, a chemical and a biological property because it directly affects all soil functions. Organic matter content was affected by site, year, and the interactions of site with year and site and treatment (Table 22). Based on the 2017 SOM, there was an overall increase of $27 \%$ in soil organic matter between 2017 and 2018. The increase in SOM was observed in 2018 compared to 2017. These results support the establishment and addition of vegetation with time. The interaction Site * Year is described in the next paragraph: Site WV11 showed lower SOM in 2017 (36.0 $\left.\pm 4.33 \mathrm{mg} \mathrm{kg}^{-1}\right)$ and $2018\left(45.5 \pm 6.29 \mathrm{mg} \mathrm{kg}^{-1}\right)$ compared to WV2 and WV16 (Table 22). Site WV16 had significantly higher SOM $\left(47.3 \pm 10.4 \mathrm{mg} \mathrm{kg}^{-1}\right)$ in 2017 , however WV2 had significantly higher SOM $\left(61.5 \pm 8.32 \mathrm{mg} \mathrm{kg}^{-1}\right)$ in 2018 which may be contributed to the higher BD and possible root mass at the surface as described previously (Table 22). The Site*Year interaction shows that although all sites show an average increase in SOM, the magnitude of the increment between sites is different. Site WV2 exhibits the highest increment in SOM (41\%) between years, followed by WV11 (26\%) and the lowest was WV16 (14\%). Within a year and for both years, the SOM contents were significantly different (Table 22).

The Site * Treatment interaction indicates that there is difference in the response of the SOM change by sites due to fertilizer application. The younger sites WV2 and WV11 show that fertilizer application caused a slight decrease in SOM of $2.2 \%$ and $8 \%$ respectively. However, 
the oldest site WV16 experienced an increase of $11.5 \%$ in SOM between the fertilizer application treatments (Table 22). The difference may be explained by the different weather conditions, specifically precipitation. Year 2018 was a record high precipitation year in WV (Table 1), and mineralization conditions may have been ideal.

\section{Bioavailable Nutrients}

The following soil bioavailable nutrients (Mehlich III) were measured in the 0-15 cm samples taken at each site before and after the experiment: $\mathrm{Al}, \mathrm{Ca}, \mathrm{Fe}, \mathrm{K}, \mathrm{Mg}, \mathrm{Na}, \mathrm{P}$, and $\mathrm{Zn}$. Bioavailable Ca was only affected by site, and they were significantly different from each other: WV11 $\left(976 \pm 253 \mathrm{mg} \mathrm{kg}^{-1}\right)<\mathrm{WV} 2\left(1257 \pm 367 \mathrm{mg} \mathrm{kg}^{-1}\right)<\mathrm{WV} 16$ $\left(1582 \pm 1049 \mathrm{mg} \mathrm{kg}^{-1}\right)$. The high bioavailable Ca reported in WV2 could be a remaining effect of the liming and seeding that occurred 2 years prior during the reclamation process, and WV16 had been managed for hay with the application lime.

Bioavailable Al, Fe, and K content showed an interaction between site and year (Table 23). The ANOVA analysis indicated that Site WV2 had significantly lower Al (444 $\left.\mathrm{mg} \mathrm{kg}^{1}\right)$ compared to WV11 and WV16 in 2017 (Table 23) and significantly lower (460 $\left.\mathrm{mg} \mathrm{kg}^{1}\right)$ than WV16 in 2018 (Table 23). Bioavailable Iron (Fe), was significantly lower in WV11 compared to WV2 and WV16 in 2017 (Table 23). Site WV16 had significantly lower K (83.2 $\left.\mathrm{mg} \mathrm{kg}^{1}\right)$ compared to WV2 and WV11 in 2018 which was not observed in 2017 (Table 23).

Sodium (Bioavailable Na) was significantly different by site (WV2 $(81.7 \pm 30.6 \mathrm{mg}$ $\left.\mathrm{kg}^{-1}\right)>$ WV16 $\left(73.4 \pm 9.22 \mathrm{mg} \mathrm{kg}^{-1}\right)>$ WV11 $\left(70.5 \pm 10.5 \mathrm{mg} \mathrm{kg}^{-1}\right)$ Appendix C Table C2). We could only speculate that the higher concentration of $\mathrm{Na}$ is related to less leaching in the younger site. Year also affected the Na content in the soil: in 2017 bioavailable Na was 19\% lower $\left(68.5 \pm 16.0 \mathrm{mg} \mathrm{kg}^{-1}\right)$ than in $2018,\left(81.5 \pm 21.1 \mathrm{~kg}^{-1}\right)$. 
Table 23. Effect of site and year on bioavailable $\mathrm{Al}, \mathrm{Ca}, \mathrm{Fe}, \mathrm{K}, \mathrm{Mg}, \mathrm{Na}, \mathrm{P}$, and $\mathrm{Zn}\left(\mathrm{mg} \mathrm{kg}^{-1}\right)$.

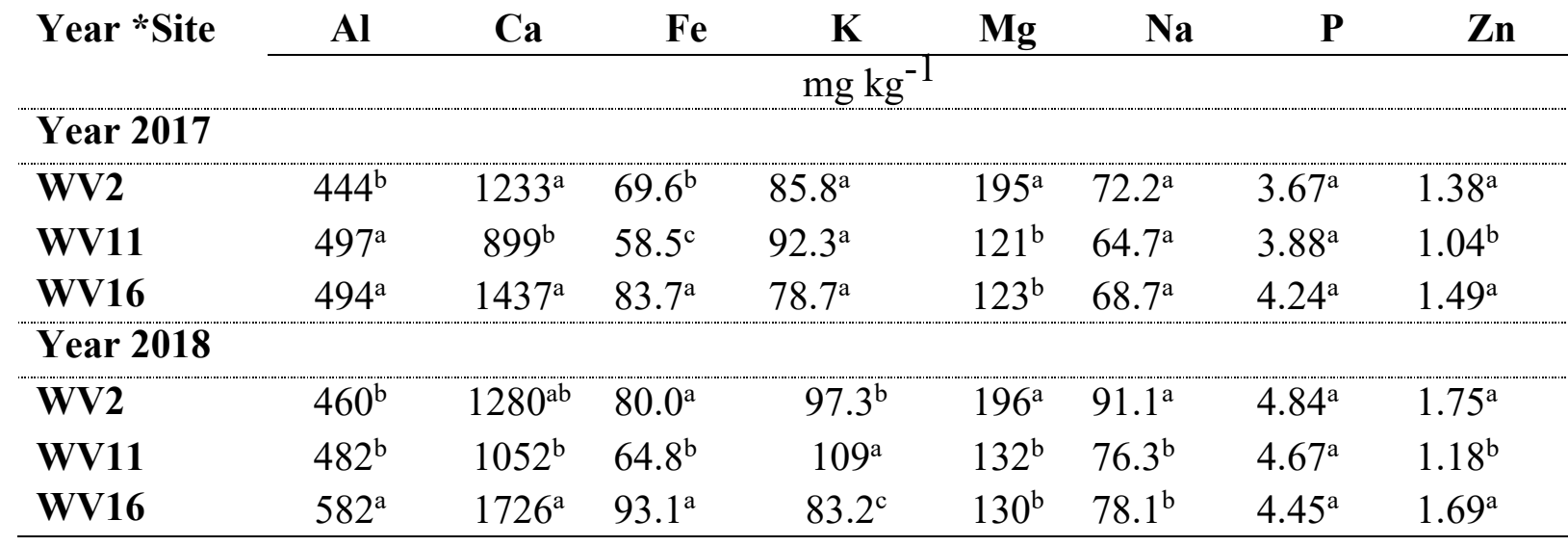

Note: Different letters in the columns indicate significant differences between sites.

Treatment and site affected bioavailable $\mathrm{Mg}$ and $\mathrm{Zn}$. Both elements presented an interaction between site and treatment (Table 24). Bioavailable Mg increased slightly in sites WV11 and WV16 when urea was applied, however in site WV2 there was a larger decrease when fertilizer was applied.

Table 24. Effect of site and treatment on bioavailable $\mathrm{Mg}$, and $\mathrm{Zn}\left(\mathrm{mg} \mathrm{kg}^{-1}\right)$.

\begin{tabular}{|c|c|c|c|c|}
\hline \multirow{3}{*}{ Site } & Mg & Zn & Mg & Zn \\
\hline & \multicolumn{2}{|c|}{ No Fertilizer } & \multicolumn{2}{|c|}{ Fertilizer } \\
\hline & \multicolumn{2}{|c|}{$\mathrm{mg} \mathrm{kg}^{-1}$} & \multicolumn{2}{|c|}{$\mathrm{mg} \mathrm{kg}^{-1}$} \\
\hline WV2 & $206 \pm 19.1^{\mathrm{a}}$ & $1.58 \pm 0.43^{\mathrm{a}}$ & $184 \pm 33.0^{\mathrm{a}}$ & $1.55 \pm 0.38^{\mathrm{a}}$ \\
\hline WV11 & $121 \pm 27.7^{b}$ & $1.17 \pm 0.28^{b}$ & $130 \pm 35.5^{b}$ & $1.05 \pm 0.21^{\mathrm{b}}$ \\
\hline WV16 & $125 \pm 20.4^{b}$ & $1.46 \pm 0.53^{\mathrm{a}}$ & $126 \pm 11.5^{b}$ & $1.73 \pm 0.67^{\mathrm{a}}$ \\
\hline
\end{tabular}

Note: Different letters in the columns indicate significant differences between sites.

Bioavailable Zn decreased in the younger sites WV2 and WV11when fertilizer was applied, however the opposite occurred in the oldest site WV16 (Table 24). Bioavailable P was the only element not related to site, and it was affected only by year. In 2017 the amount of bioavailable P $(3.93 \pm 1.72)$ was significantly different from $4.65 \pm 1.49$ in $2018(\mathrm{p}=0.0164)$. 


\section{Biological Properties}

\section{Vegetative Growth}

The existing vegetation at each site is the result of years of weather and soil and plant interactions at each site. The revegetation for each site started with the same mixture of species (personal communication Dr. Jeffrey Skousen). Assuming the same baseline at time zero of the reclamation for all the sites, the surveys will give a picture of changes that occurred as an effect of time since reclamation. The existing vegetation was subjected to urea fertilization, and changes in biomass and composition were measured.

Before starting the fertilization experiment in spring of 2017, a baseline or initial vegetation survey was performed. The following year, another spring survey was performed. Both surveys were performed before fertilization was applied for that year, however 2018 may have a residual fertilizer effect from 2017.

There was an interaction between treatment and year on legume and grass percentage for the spring survey. This interaction resulted in significantly lower legumes $(22 \%)$ with fertilizer treatment in 2018 compared to no fertilizer (34\%) (Table 25). Legumes are known to fix nitrogen, and therefore with the application of urea fertilizer in 2018, other plant families such as forbs and grasses were able to compete and result in higher percentage across the sites. Grasses were highest (33\%) with fertilizer treatment in 2018 compared to 2017 (Table 25). An interaction was observed between treatment and site on legumes, forbs, and grasses (Table 25). No fertilizer on WV11 had the highest amount of legumes (38 $19 \%)$, and fertilizer on WV16 had the lowest amount of legumes $(27 \pm 14 \%)$. Fertilizer on WV2 had the highest amount of forbs (47 $\pm 14 \%)$, and no fertilizer on WV11 had the lowest amount of forbs $(15 \pm 11 \%)$. Fertilizer on WV11 had the highest amount of grasses $(43 \pm 22 \%)$, and no fertilizer on WV2 had the lowest 
amount of grasses $(14 \pm 6 \%)$.

Table 25. Descriptive statistics and analysis of variance for initial or Spring plant diversity survey.

$\begin{array}{ccc}\text { Legumes } & \text { Forbs } & \text { Grasses } \\ & \% & \end{array}$

\section{Treatment}

No Fertilizer

Fertilizer

Site

WV2

WV11

WV16

Year

2017

2018

\section{Treatment*Site}

No Fertilizer*WV2

No Fertilizer*WV11

No Fertilizer*WV16

Fertilizer*WV2

Fertilizer*WV11

Fertilizer*WV16

Treatment* Year

2017-No Fertilized

2018-No Fertilized

2017-Fertilized

2018-Fertilized

$$
35 \pm 15^{\text {a }}
$$

$31 \pm 16^{\mathrm{b}}$

$29 \pm 15^{\mathrm{a}}$

$34 \pm 20^{\text {a }}$

$28 \pm 17^{\mathrm{a}}$

$28 \pm 20^{\mathrm{a}}$

$32 \pm 16^{\mathrm{ab}}$

$37 \pm 18^{\mathrm{a}}$

$31 \pm 13^{b}$

$39 \pm 15^{\mathrm{a}}$

$28 \pm 14^{b}$

$34 \pm 14$

$38 \pm 19$

$34 \pm 11$

$29 \pm 17$

$36 \pm 18$

$27 \pm 14$

$37 \pm 17$

$34 \pm 13$

$40 \pm 14$

$22 \pm 13$
$43 \pm 13^{\mathrm{a}}$

$16 \pm 13^{\mathrm{c}}$

$36 \pm 14^{\mathrm{b}}$

$27 \pm 16^{b}$

$36 \pm 19^{\mathrm{a}}$

$38 \pm 11$

$15 \pm 11$

$34 \pm 13$

$47 \pm 14$

$16 \pm 15$

$38 \pm 15$

$25 \pm 15$

$33 \pm 15$

$28 \pm 16$

$39 \pm 21$
$27 \pm 18$

$15 \pm 7^{\mathrm{c}}$

$43 \pm 19^{\mathrm{a}}$

$25 \pm 14^{\mathrm{b}}$

$25 \pm 17^{\mathrm{b}}$

$30 \pm 20^{\mathrm{a}}$

$14 \pm 6$

$43 \pm 15$

$25 \pm 14$

$15 \pm 8$

$43 \pm 22$

$25 \pm 15$

$28 \pm 16$

$23 \pm 15$

$33 \pm 22$ 
Grand Mean

B.

Block

Treatment

Site

Year

Treatment*Site

Treatment*Year
$33 \pm 16$

$31 \pm 18$

$28 \pm 18$

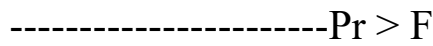

0.0268

0.6464

0.4349

0.0853

0.0623

0.8694

0.1295

$<0.0001$

$<0.0001$

$<0.0001$

0.0003

0.0447

$<0.0001$

0.0003

0.0447

0.0086

0.0890

Same letters in the same columns indicate no statistically significant differences at $\mathrm{p}<0.10$. *Average \pm Standard Deviation

An interaction of year on forbs was observed (Table 25). Forbs were higher (36\%) in 2018 compared to 2017 (27\%). The application of urea and increased precipitation recorded in 2018 allowed forbs to compete with legumes and resulted in increased growth.

An overall analysis of the second plant family diversity survey for 2017 and 2018 shows an interaction of treatment on legumes (Table 26). A significantly lower percentage of legumes $(18 \pm 12 \%)$ was observed with fertilizer application compared to no fertilizer $(28 \pm 17 \%)$. These results are similar to those in the initial vegetation survey. Site also had an effect on legumes, where WV11 had the most legumes $(32 \pm 20 \%)$ and WV2 had the least $(16 \pm 10 \%)$.

An interaction between treatment and site was observed in the amount of forbs and grasses (Table 26). Fertilizer on WV2 had the greatest amount of forbs $(68 \pm 9 \%)$, and fertilizer on WV11 had the lowest amount of forbs $(17 \pm 13 \%)$. Site WV2 with no fertilizer showed the least amount of

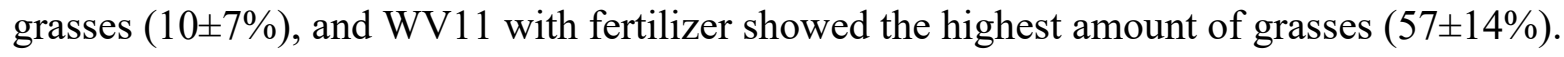

Site and year also affected the growth of forbs and grasses (Table 26). In 2017, WV2 had the highest amount of forbs $(62 \pm 12 \%)$ and WV11 had the lowest amount $(13 \pm 12 \%)$. There was an opposite reaction for grasses, with WV11 presenting the most grass $(47 \pm 20 \%)$ and WV2 
presenting the least $(11 \pm 5 \%)$. These results are similar to those reported in Experiment II.

Table 26. Descriptive statistics and analysis of variance for second, or Fall, plant diversity survey

$\begin{array}{ccc}\text { Legumes } & \begin{array}{c}\text { Forbs } \\ \%\end{array} & \text { Grasses } \\ & \end{array}$

\section{Treatment}

No Fertilizer

Fertilizer

Site

WV2

WV11

WV16

Year

2017

2018

\section{Treatment*Site}

No Fertilizer*WV2

No Fertilizer*WV11

No Fertilizer*WV16

Fertilizer*WV2

Fertilizer*WV11

Fertilizer*WV16

Site*Year

$2017 *$ WV2

2017*WV11

$2017 *$ WV16

2018*WV2

2018*WV11
$28 \pm 17^{\mathrm{a}^{*}}$

$18 \pm 12^{b}$

$16 \pm 10^{\mathrm{c}}$

$32 \pm 20^{\mathrm{a}}$

$23 \pm 9^{b}$

$24 \pm 16^{\mathrm{a}}$

$23 \pm 14^{\mathrm{a}}$

$21 \pm 10$

$41 \pm 22$

$25 \pm 9$

$12 \pm 8$

$23 \pm 14$

$20 \pm 8$

$16 \pm 9$

$33 \pm 23$

$22 \pm 9$

$16 \pm 11$

$30 \pm 18$
$38 \pm 21^{\mathrm{a}}$

$37 \pm 25^{\mathrm{a}}$

$26 \pm 18^{b}$

$41 \pm 21^{\mathrm{a}}$

$14 \pm 7^{b}$

$44 \pm 19^{\mathrm{a}}$

$44 \pm 16^{\mathrm{a}}$

$28 \pm 15^{b}$

$33 \pm 22^{a}$

$35 \pm 20^{a}$

$40 \pm 22^{\mathrm{a}}$

$10 \pm 7$

$30 \pm 15$

$39 \pm 17$

$17 \pm 8$

$57 \pm 14$

$50 \pm 13$

$27 \pm 15$

$62 \pm 12$

$11 \pm 5$

$13 \pm 12$

$47 \pm 20$

$29 \pm 14$

$41 \pm 15$

$65 \pm 8$

$16 \pm 9$

$26 \pm 14$ 


$\begin{array}{lccc}2018 * \text { WV16 } & 23 \pm 9 & 28 \pm 16 & 47 \pm 16 \\ \text { Grand Mean } & 23 \pm 15 & 37 \pm 23 & 34 \pm 21 \\ & ----------------P r & \text { F----------------- } \\ \text { Block } & 0.4432 & 0.2340 & 0.5027 \\ \text { Treatment } & <0.0001 & 0.8649 & <0.0001 \\ \text { Site } & <0.0001 & <0.0001 & <0.0001 \\ \text { Year } & 0.9216 & 0.0305 & 0.5247 \\ \text { Treatment*Year } & 0.6335 & 0.1328 & 0.6177 \\ \text { Treatment*Site } & 0.1226 & 0.0510 & 0.0021 \\ \text { Site*Year } & 0.9239 & 0.0485 & 0.0421\end{array}$

Same letters in the same columns indicate no statistically significant differences at $\mathrm{p}<0.10$. *Average \pm Standard Deviation

\section{Aboveground Biomass}

Aboveground biomass was harvested at each of the eighteen (18) sample points on all three sites for 2017 and 2018. An interaction of Site*Year was observed for the spring cut prefertilization (Table 27, Figure 16). Site WV16 (6.17 $\left.\pm 1.19 \mathrm{Mg} \mathrm{ha}^{-1}\right)$ showed the highest amount of aboveground biomass for 2017, followed by WV11(5.33 $\left.\pm 1.32 \mathrm{Mg} \mathrm{ha}^{-1}\right)$ and WV2 (3.42 \pm 0.58 $\mathrm{Mg} \mathrm{ha}^{-1}$ ). The results in 2017 for cut one were expected due to it being the first biomass harvest. Sites were assumed to have little to no disturbance since reclamation, affecting soil development and vegetation establishment on the oldest and youngest sites. However, in 2018, WV11 showed the highest vegetation regrowth, followed by WV16, and WV2. These results may be due to the type of vegetation present on each site and growth rate of species.

The fall cut (post-fertilization) was impacted by the interaction of Site*Treatment*Year (Table 27). In 2017, WV11 exhibited the highest biomass for cut two without fertilizer, 
however WV2 showed the highest biomass with fertilizer treatment (Figure 17). In 2018, the second biomass harvest showed significantly higher biomass in the oldest site for both fertilizer and no fertilizer treatments, followed by the two youngest sites (Figure 18). These results show that after two years of fertilizer application, the oldest site produced the most biomass compared to the two younger sites, which was expected due to soil development and productivity over time. Regardless of treatment, the oldest site shows continuous increase in aboveground biomass with each cut after the initial 2017 baseline (Figure 16).

Table 27. Descriptive statistics and analysis of variance for biomass

Cut 1

Treatment

No Fertilizer

Fertilizer

Site

WV2

WV11

WV16

Year

2017

2018

Treatment*Site

No Fertilizer*WV2

No Fertilizer*WV11

No Fertilizer*WV16

Fertilizer*WV2

Fertilizer*WV11

Fertilizer*WV16
$4.10 \pm 1.63^{\mathrm{a}}$

$4.00 \pm 1.59^{\mathrm{a}}$

$\mathrm{Mg} \mathrm{ha}^{-1}$
Cut 2

$\begin{array}{cc}\mathrm{Mg} \mathrm{ha}^{-1} & \\ 4.10 \pm 1.63^{\mathrm{a}} & 2.40 \pm 0.99^{\mathrm{b}} \\ 4.00 \pm 1.59^{\mathrm{a}} & 2.64 \pm 1.09^{\mathrm{a}}\end{array}$

$2.92 \pm 0.72^{b^{*}}$

$2.42 \pm 0.81^{\mathrm{b}}$

$4.66 \pm 1.35^{\mathrm{a}}$

$2.28 \pm 0.70^{\mathrm{b}}$

$4.56 \pm 1.89^{\mathrm{a}}$

$2.84 \pm 1.40^{\mathrm{a}}$

$4.97 \pm 1.57^{\mathrm{a}}$

$2.05 \pm 0.73^{b}$

$3.13 \pm 0.99^{b}$

$3.01 \pm 1.10^{\mathrm{a}}$

$3.04 \pm 0.82$

$2.09 \pm 0.73$

$4.75 \pm 1.53$

$2.44 \pm 0.77$

$4.53 \pm 1.87$

$2.68 \pm 1.29$

$2.81 \pm 0.60$

$2.76 \pm 0.76$

$4.58 \pm 1.18$

$2.15 \pm 0.62$

$4.60 \pm 1.97$

$3.00 \pm 1.53$ 
Grand Mean

Block

Treatment

0.7919

0.4363

Site

0.5647

0.0971

Year

$<0.0001$

0.0057

$<0.0001$

$<0.0001$

Treatment*Site

0.7837

0.0437

Site*Year

$<0.0001$

$<0.0001$

Site*Treatment*Year

0.6764

0.0503

Same letters in the same columns indicate no statistically significant differences at $\mathrm{P}<0.10$. $*$ Average \pm Standard Deviation

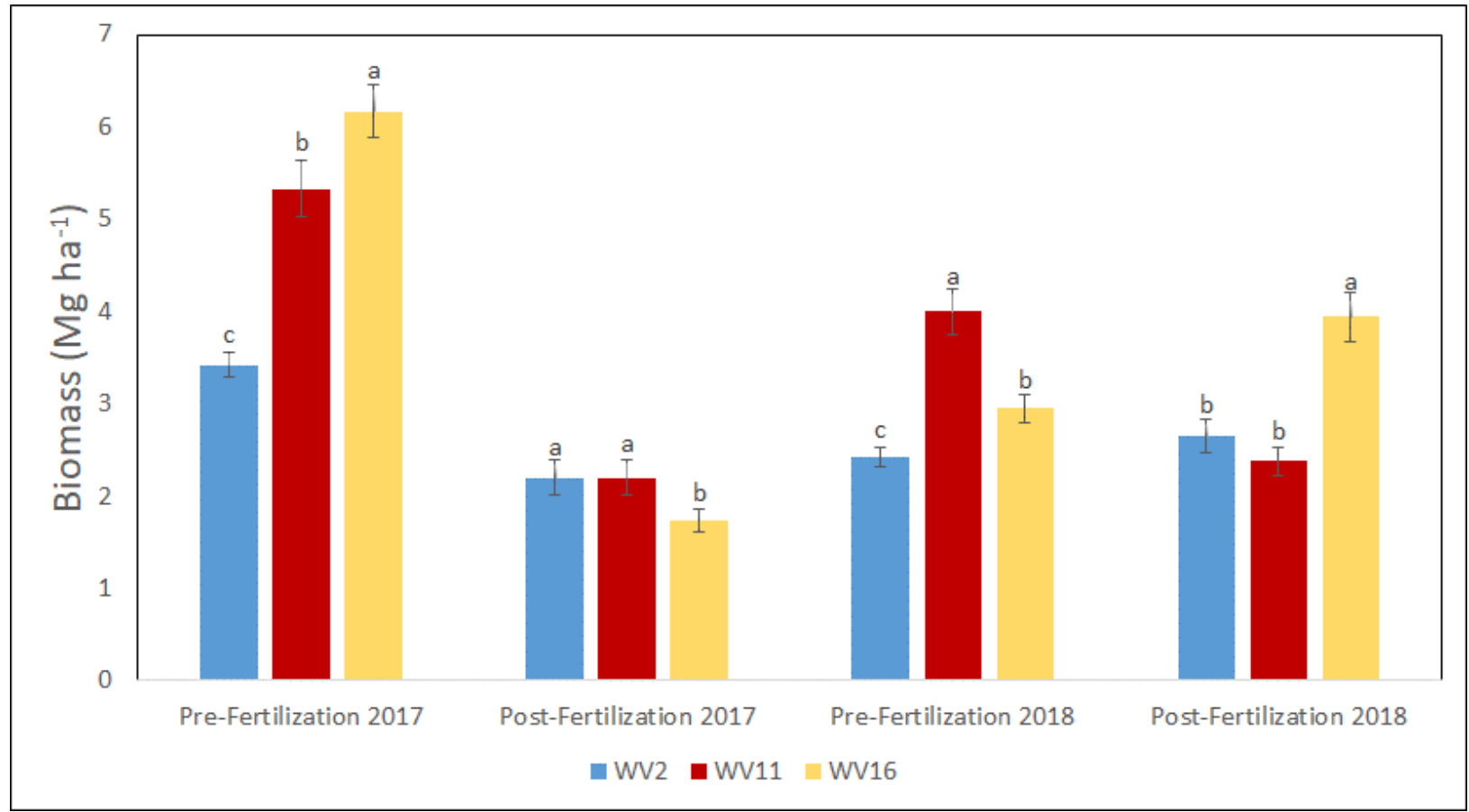

Figure 16. Comparison of aboveground biomass by site, year, and harvest. 


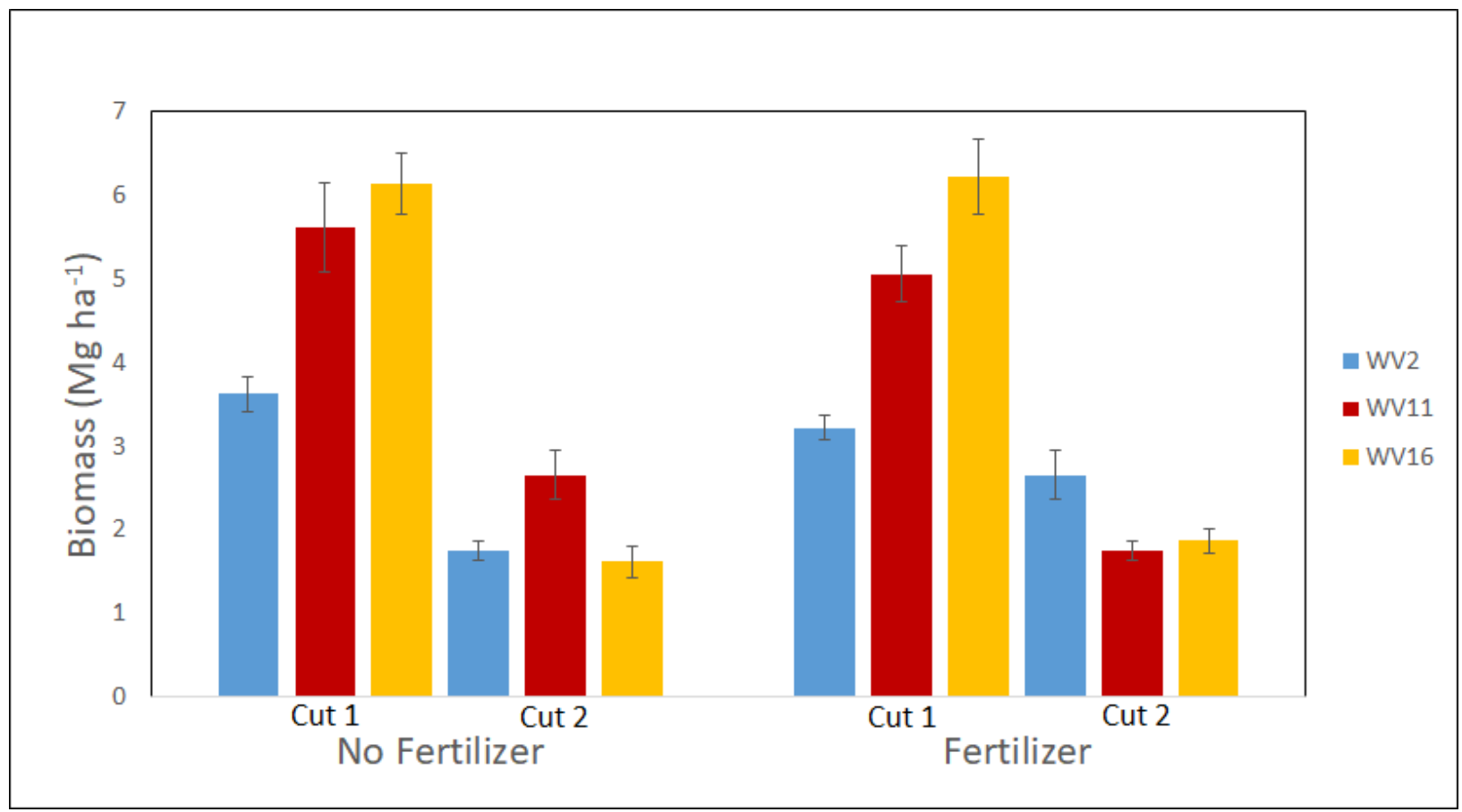

Figure 17. Interaction of Site*Treatment*Year on biomass for 2017.

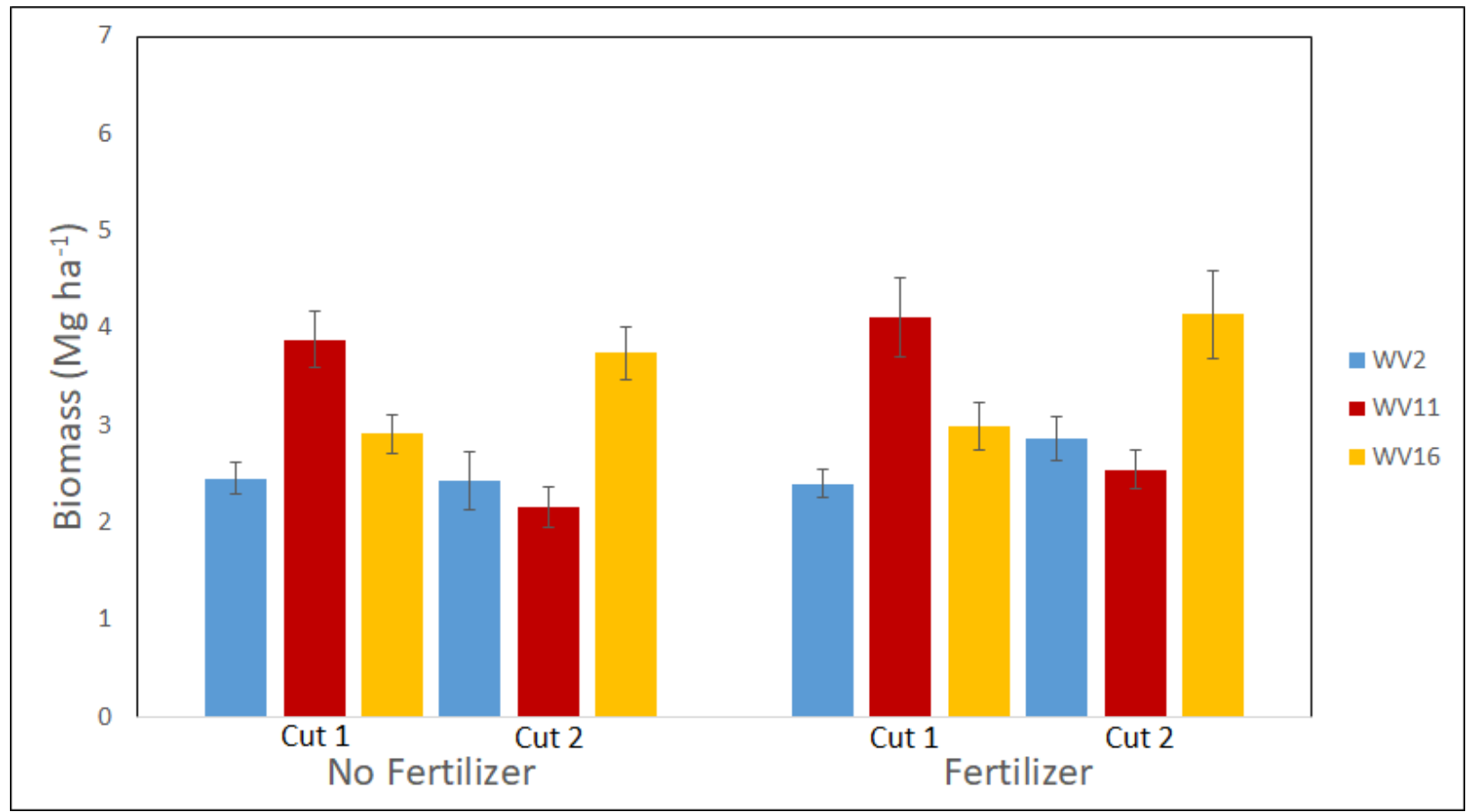

Figure 18. Interaction of Site*Treatment*Year on biomass for 2018. 


\section{CHAPTER 5. CONCLUSIONS}

The findings of this research increase the knowledge and understanding of soil health in reclaimed mine soils and methods that are suitable to be used in these disturbed soils. Even with the decline of coal mining, many areas that have been mined and reclaimed are now being sold to local landowners and farmers with the intent of production. With the potential use of reclaimed lands by landowners, it is important to understand the pedologic processes and resulting soil health indicators with time since reclamation to estimate potential production. Few studies have conducted methodology assessments and production response on reclaimed mine soils of various ages.

The results obtained with the NRCS Soil Quality Test Kit assessment methods, showed similar trends to the standard methods for physical, chemical and biological indicators, however were less sensitive to differences between sites and tended to underestimate measurements. It was observed that the NRCS Soil Quality Test Kit resulted in similar trends but significantly lower BD values compared to the standard method for WV2, WV11, WV16 and WV32 with BD of $1.37 \pm 0.11 \mathrm{Mg} \mathrm{m}^{-3}$ and $1.53 \pm 0.15 \mathrm{Mg} \mathrm{m}^{-3} ; 1.34 \pm 0.06 \mathrm{Mg} \mathrm{m}^{-3}$ and $1.48 \pm 0.12 \mathrm{Mg} \mathrm{m}^{-3}$; $1.35 \pm 0.15 \mathrm{Mg} \mathrm{m}^{-3}$ and $1.45 \pm 0.11 \mathrm{Mg} \mathrm{m}^{-3} ; 1.12 \pm 0.17 \mathrm{Mg} \mathrm{m}^{-3}$ and $1.37 \pm 0.32 \mathrm{Mg} \mathrm{m}^{-3}$ respectively. These results were also observed for EC, and were likely consequence of the sampling depth at which measurements were taken for each method. Saturated hydraulic conductivity, $\mathrm{pH}$, and respiration showed similar results for both methods. This study successfully compared the NRCS Soil Quality Test Kit methods with standard methods, and supports the objectives of Experiment I. The results indicate that some NRCS Soil Quality Test Kit methods are representative of standard methods, however not all test kit methods were as sensitive to determine differences between sites. 
Regarding time since reclamation effect on soil health indicators, the older site showed improved soil health indicators compared to the younger site. It was observed that corrected BD was significantly lower in WV16 $\left(1.46 \pm 0.12 \mathrm{Mg} \mathrm{m}^{-3}\right)$ compared to WV2 $\left(1.51 \pm 0.15 \mathrm{Mg} \mathrm{m}^{-3}\right)$. Similar trends were measured in WA and SOM, with WV16 having significantly higher waterstable aggregates than WV11 and WV2, and significantly more SOM than WV11. These results are explained by the increased soil development and pedologic processes that occurred with time since reclamation, and support the hypothesis of Experiment II that soil health indicators will improve with time since reclamation. However, not all the indicators behaved the same, $\mathrm{pH}$ and SOM were observed to be significantly lower in WV11 compared to WV2 and WV16. The pH may be explained by differences in dominant and mixed parent material of sandstone and shale, and the application of lime on WV2 during reclamation and WV16 during management. The lower $\mathrm{pH}$ in WV11 may directly affect biological activity resulting in lower SOM. Vegetation is a soil health indicator that was studied in Experiment II, and represents the interaction weather, soil, and management. At the beginning of this study in spring 2017, the vegetation surveys that were conducted, indicated that WV2 exhibited a significantly higher percentage of forbs (36.7\%) and lower grasses (16.7\%) compared to WV11 and WV16. These results may be explained by higher BD observed in WV2, which may have limited the growth of legumes and grasses, as well as the concept of pioneer species (including weedy plants) colonizing disturbed areas. By 2018, grasses had significantly increased on WV2 and legumes had decreased. This may be explained by time increasing and allowing the growth and establishment of grasses on the youngest site, and the fact that 2018 had record breaking rainfall which seemed to affect the growth of legumes and grasses. The oldest site showed more equal parts of legumes, forbs, and grasses compared to WV2 showing more forbs, and WV11 showing more grasses. This observation may be due to 
increased soil development and established soil health able to support diverse plant populations. These results support the hypothesis that plant diversity would increase with time since reclamation.

When management represented by $\mathrm{N}$ fertilizer rate, was imposed to the different age mine sites, the different treatment did not significantly affect physical or chemical soil health indicators. However, indicators such as BD, DA, and SOM improved over the course of this study between 2017 and 2018. The older sites, WV11 and WV16, also showed improved indicators with time since reclamation. Growth of legumes was affected by fertilizer treatment for both spring and fall surveys, with higher legumes observed without treatment compared to with fertilizer treatment. These results were expected due to applied urea allowing non-nitrogen fixers to compete with the legumes. Legumes, forbs, and grasses were impacted by treatment and site for the spring survey with no fertilizer on WV11 having more legumes, fertilizer on WV2 having more forbs, and fertilizer on WV11 having more grasses.

Initial aboveground biomass showed an interaction between site with WV16 $(6.17 \pm 1.19$ $\left.\mathrm{Mg} \mathrm{ha}^{-1}\right)$ having the most biomass, followed by WV11 (5.33 $\left.\pm 1.32 \mathrm{Mg} \mathrm{ha}^{-1}\right)$ and WV2 $(3.42 \pm 0.58$ $\left.\mathrm{Mg} \mathrm{ha}^{-1}\right)$. A significant steady increase of biomass was observed in the oldest site as a response to the fertilizer application, compared to WV2 and WV11. These results support hypothesis of Experiment III that with time since reclamation, soil development will improve, and as a result higher vegetative growth will be observed. However, although some evidence was observed as described in the previous paragraph, Experiment III was not able to conclude that time since reclamation affected the potential for agricultural land use and management.

The results of this research show the effectiveness of the NRCS Soil Quality Test Kit to standard methods in reclaimed mine soils. The NRCS Soil Quality Test Kit may be used 
qualitatively in these disturbed soils, and improvements or modifications could be made to improve quantitative outcomes of the test kit methods.

Overall results show improvement in soil health indicators and higher response to management with time since reclamation, which supports soil development over time. These results are specific to the WV reclaimed mine sites used in this study, however the methods discussed may be used in other disturbed soils. This research is may be applied when determining soil health measurement methods, management practices in reclaimed mine soils, and potential agricultural productivity for these areas. 


\section{REFERENCES}

Abu-hamdeh, N.H. 2003. Compaction and subsoiling effects on corn growth and soil bulk density. Soil Sci. Soc. Am. J. 67:1213-1219.

An, Sh-Sh, F. Darboux, and M. Cheng. 2013. Revegetation as an efficient means of increasing soil aggregate stability on the Loess Plateau (China). .Geoderma 209-210: 75-85

Andrews, S.S., D.L. Karlen, and C.A. Cambardella. 2004. The soil management assessment framework: A quantitative soil quality evaluation method. Soil Sci. Soc. Am. J. 68:1945 1962.

Arshad, M.A., Martin, S. 2002. Identifying critical limits for soil quality indicators in agro ecosystems. Agriculture, Ecosystems and Environment 88: 153-160.

Bendfeldt, E.S., J.A. Burger, and W.L. Daniels. 2001. Quality of amended mine soils after sixteen years. Soil Sciences Society of American Journal. 65:1736-1744.

Berg, G. and K. Smalla. 2009. Plant species and soil type cooperatively shape the structure and function of microbial communities in the rhizosphere. FEMS Microbiol Ecol. 68:1-13.

Bi, Y., H. Zou and Ch. Zhu. 2014. Dynamic monitoring of soil bulk density and infiltration rate during coal mining in sandy land with different vegetation. International Journal of Coal Science \& Technology. 1:198-206. DOI 10.1007/s40789-014-0025-2

Brady, N.C. and R.R. Weil. 2004. Elements of the Nature and properties of Soils. Prentice hall, Upper Saddle River, NJ. Pp. 363.

Bunemann, E.K., Bongiorno, G., Bai, Z., Creamer, R.E., De Deyn, G., de Goede, R., Flekens, L., Geissen, V., Kuyper, T.W., Mader, P., Pulleman, M., Sukkel, W., van Groenigen, J.W.,and L. Brussaard. 2018. Soil quality - A critical review. Soil Biology and Biochemistry 
120:105-125.

Bussler, B.H., W.R. Byrnes, P.E. Pope and W.R. Chaney. 1984. Properties of minesoil reclaimed for forest land use. Soil Sci. Soc. Am. J. 48:178-184.

Chan, K.Y. and C.E. Mullins. 1994. Slaking characteristics of some Australian and British soils. European J. of Soil Sci. 45:273-283.

Chaudhuri, S., Pena-Yewtukhiw, E.M., McDonald, L.M., Skousen, J., and M. Sperow. 2011. Land use effects on sample size requirements for soil organic carbon stock estimations. Soil Sci. 176:110-114.

Chaudhuri, S., Pena-Yewtukhiw, E.M., McDonald, L.M., Skousen, J., and M. Sperow. 2012. Early C sequestration rate changes for reclaimed minesoils. Soil Sci. 00:1-8.

Childs, H. 2015. A brief community and economic profile Morgantown and Monongalia County, West Virginia. Retrieved March 28, 2018, from http://moncpc.org/wp content/uploads/2017/03/2015-Community-Profile.pdf

Ciolkosz, E.J., Cronce, R.C., Cunninghman, R.L., and G.W. Petersen. 1985. Characteristics, genesis, and classification of Pennsylvania minesoils. Soil Sci. 139(3):232-238.

Cornell University Cooperative Extension. 2008. Soil Organic Matter. Retrieved January 7, 2019 from http://franklin.cce.cornell.edu/resources/soil-organic-matter-fact-sheet

Cornell University. 2010. PO 39. Describe how soil $\mathrm{pH}$ affects the availability of each nutrient. Retrieved February 12, 2019. https://nrcca.cals.cornell.edu/nutrient/CA5/CA0539.php Curtin, D., Campbell, C.A., Jalil, A. 1998. Effects of acidity on mineralization: pH-dependence of organic matter mineralization in weakly acid soils. Soil Biology \& Biochemistry 30(1):57-64.

Dane, J.H., and Topp, G.C., editors. 2002. Methods of soil analysis: Part 4 physical methods. 
SSSA Book Ser. 5. SSSA, Madison, WI. p. 273-278.

Diaz-Zorita, M., Perfect, E., Grove, J.H. 2002. Disruptive methods for assessing soil structure.

Soil \& Tillage Research 64: 3-22.

Doran. J.W. and T.B. Parkin. 1994. Defining and assessing soil quality. Defining Soil Quality for a Sustainable Environment. SSSA 35:3-21.

Doran, J.W and T.B. Parkin. 1996. Quantitative indicators of soil quality. In: Doran J.W., Coleman, D.C., Bezdieck, D.F., Stewart, B.A., (Eds.), Defining soil quality for a sustainable environment, Madison, WI. Soil Science Society of America 35: 3-21.

Doran, J.W. and M. Safely. 1997. Defining and assessing soil health and sustainable productivity. Biological Indicators of Soil health. CAB International. 1-28.

Doran, J.W., Ketler, T., and M. Tsivou. 1997. Field and laboratory Solvita soil test evaluation. USDA-ARS, University of Nebraska, Lincoln, Nebraska.

Doran, J.W. and M.R. Zeiss. 2000. Soil health and sustainability: managing the biotic component of soil quality. Applied Soil Ecology 15: 3-11.

Edwards, C. A. 2001. The Living Soil: Earthworms. USDA-NRCS Soil Biology Primer.

Retrieved January 6, 2019. ttp:/www.nrcs.usda.gov/wps/portal/nrcs/ main/soils/health/biology/ The Ohio State University.

EIA. 2017. West Virginia profile overview. Retrieved February 5, 2018, from https://www.eia.gov/state/?sid=WV

Fierer N \& Jackson RB (2006) The diversity and biogeography of soil bacterial communities. P Natl Acad Sci USA 103: 626-631

Follett, R.H., Westfall, D.G., and R.L. Croissant. 1987. Soil test recommendation comparison study. J. Agron. Educ. 16(2):73-76. 
Fuji, K. 2014. Soil acidification and adaptations of plants and microorganisms in Bornean tropical forests. Ecological Research 29: 371-381 DOI 10.1007/s11284-014-1144-3

Gamie, R. and F. De Smedt. 2018. Experimental and statistical study of saturated hydraulic conductivity and relations with other soil properties of a desert soil. European Journal of Soil Science. 69: 256-264.

Garcia-Palacios, P., F.T. Maestre, R.D. Bardgett, and H. de Kroon. 2012 Plant responses to soil heterogeneity and global environment. Journal of Ecology. 100: 1303-1314. doi:10.1111/j.1365-2745.2012.02014.x

García-Gutiérrez, C, Y. Pachepsky, and M.A, Martín. 2018. Technical note: Saturated hydraulic conductivity and textural heterogeneity of soils. Hydrology and Earth System Sciences. 22: 3923-3932.

Gildon, A., and Rimmer, D.L. 1993. Soil respiration on reclaimed coal-mine spoil. Biology and Fertility of Soils 16(1):41-44.

Gillison, A.N., Jones, D.T., Susilo, F.X., Bignell, D.E. 2003. Vegetation indicates diversity of soil macroinvertebrates: a case study with termites along a land-use intensification gradient in lowland Sumatra. Organisms Diversity \& Evolution 3(2): 111-126.

Gregory, J.H., Dukes, M.D., Jones, P.H., and G.L. Miller. 2006. Effect of urban soil compaction on infiltration rate. Journal of Soil and Water Conservation 61(3):117-124.

Grisso, R., Alley, M., Holshouser, D., and W. Thomason. 2009. Precision farming tools: Soil electrical conductivity. Retrieved January 8, 2019 fromhttps://pdfs.semanticscholar.org/ e88b/d71059c64b1dac601981c439aa9708993abf.pdf Virginia Tech University.

Groninger, J., Skousen, J., Angel, P., Barton, C., Burger, J., and C. Zipper. 2007. Chapter 8: Mine reclamation practices to enhance forest development through natural succession. In 
Forest Reclamation Advisory 5:1-7.

Haering, K.C., Daniels, W.L., and Roberts, J.A. 1993. Changes in mine soil properties resulting from overburden weathering. J. Environ. Qual. 22:194-200.

Haering, K.C., Daniels, W.L., Galbraith, J.M. 2004. Appalachian mine soil morphology and properties: effects of wreathing and mining method. Soil Science Society of America Journal 68:1315-1325.

Haney, R.L., Brinton, W.F., Evans, E. 2008. Soil CO2 respiration: Comparison of chemical titration, CO2 IRGA analysis and the Solvita gel system. Renewable Agriculture and Food Systems 23(2): 171-176.

Harris, R.F., Karlen, D.L., Mulla, D.J. 1996. A conceptual framework for assessment and management of soil quality and health. Soil Science Society of America Journal 49:61 82.

Heiri, O., Lotter, A.F., Lemcke, G. 2001. Loss on ignition as a method for estimating organic and carbonate content in sediments: reproducibility and comparability of results. Journal of Paleolimnology 25: 101-110.

Hilgard E.W. 1914. Soils, their formation, properties, composition, and relations to climate and plant growth in the humid and arid regions. The Macmillan Company, New York.

Hillel, D. 1982. Introduction to soil physics. 2nd ed. Academic Press, San Diego, CA.

Howell, D.M., D. Gupta. B.D. Pinno, and M.D. MacKenzie. 2017. Reclaimed soils, fertilizer, and bioavailable nutrients: Determining similarity with natural benchmarks over time. Canadian Journal of Soil Science. 2017. 97: 149-158.

Huggett, R.J. 1998. Soil chronosequences, soil development, and soil evolution: a critical review. Catena 32:155-172.

Indorante, S.J., Grantham, D.R., Dunker, R.E., Darmody, R.G. 1992. Mapping and classification 
of minesoils: Past, present, and future. p. 233-241. In R.E. Dunker et al. (ed.) Prime farmland reclamation. Proc. 1992 Natl. Symp. prime farmland reclamation, St. Louis, MO, 10-14 Aug. Dep. Agron., Univ. Illinois, Urbana.

Janzen, H.H. 1993. Soluble salts. p. 161-166. In: M.R. Carter (ed.) Soil sampling and methods of analysis. Canadian Society of Soil Science. Lewis Publ., Boca Raton.

Jastrow, J.D. 1987. Changes in soil aggregation associated with tallgrass prairie restoration. Amer. J. Bot. 74(11):1656-1664.

Kibblewhite, M.G., Ritz, K., and M.J. Swift. 2007. Soil health in agricultural systems. Phil. Trans. R. Soc. 363:685-701.

Kidd, J. P. Manning, J. Simkin, S. Peacock, and E. Stockdale. 2017. Impacts of 120 years of fertilizer addition on a temperate grassland ecosystem. PLoS ONE 12: e0174632. https://doi.org/10.1371/journal.pone.0174632. Retrieved July 24, 2018.

Laishram, J., Saxena, K.G., Maikhuri, R.K., Rao, K.S. 2012. Soil quality and health: a review. International Journal of Ecology and Environmental Sciences 38(1): 19-37.

Lange, M., Eisenhauer, N., Sierra, C.A., Bessler, H., Engels, C., Griffiths, R.I., Mellado Vazquez, P.G., Malik, A.A., Roy, J., Scheu, S., Steinbeiss, S., Thomson, B.C., Trumbore, S.E., and G. Gleixner. 2015. Plant diversity increases soil microbial activity and soil carbon storage. Nature Communications. DOI: 10.1038/ncomms7707.

Larson, W.E., and F.J. Pierce. 1991. Conservation and enhancement of soil quality. In Evaluation for sustainable land management in the developing world. Vol. 2. Technical papers. IBSRAM Proceedings No. 12 (2). Board for Soil Res. and Manage. Bangkok, Thailand. Lehman, M.R., Cambardella, C.A., Stott, D.E., Acosta-Martinez, V., Manter, D.K., Buyer, J.S., Maul, J.E., Smith, J.L., Collins, H.P., Halvorson, J.J., Kremer, R.J., Lundgren, J.G., Ducey, 
T.F., Jin, V.L., and D.L. Karlen. 2015. Understanding and enhancing soil biological health: The solution for reversing soil degradation. Sustainability. 7:988-1027.

Liebig, M.A, Doran, J.W., and J.C. Gardner. 1996. Evaluation of field test kit for measuring selected soil quality indicators. Agron. J. 88:683-686.

Mausel, P.W., 1971. Soil quality in Illinois—an example of a soils geography resource analysis. The Professional Geographer 23, 127-136.

Mehlich, A. 1984. Mehlich 3 soil test extractant: A modification of Mehlich 2 extractant. Communications in Soil Science and Plant Analysis 15(12): 1409-1416.

Moebius-Clune, B.N., Moebius-Clune, D.J., Gugino, B.K., Idowu, O.J., Schindelbeck, R.R., Ristow, A.J., van Es, H.M., Thies, J.E., Shayler, H.A., McBride, M.B., Kurtz, K.S.M., Wolfe, D.W., and G.S. Abawi. 2017. Comprehensive assessment of soil health. The Cornell Framework. Third Ed. The Cornell University. Ithaca, New York.

Moldenke, A. R. 2001. The Living Soil: Arthropods. USDA-NRCS Soil Biology Primer. Retrieved January 6, 2019.www.nrcs.usda.gov/wps/portal/nrcs/main/soils/health/biology/ Oregon State University.

Moujahid, L.E., Le Roux, X., Michalet, S., Bellver, F., Weigelt, A., and F. Poly. 2017. Effect of plant diversity on the diversity of soil organic compounds. PLoS ONE 12(2): e0170494. doi:10.1371/journal.pone. 0170494

Mukhopadhyay, S., Maiti, S.K., and R.E. Masto. 2014. Development of mine soil quality index (MSQI) for evaluation of reclamation success: a chronosequence study. Ecological Engineering 71: 10-20.

Mukhopadhyay, S., Masto, R.E., Yadav, A., George, J., Ram, L.C., and S.P. Shukla. 2016. Soil quality index for evaluation of reclaimed coal mine spoil. Science of the Total Environment 
542: $540-550$.

NRCS-USDA. 2014. Inherent factors affecting bulk density and available water. Guides for Educators.https://www.nrcs.usda.gov/Internet/FSE_DOCUMENTS/nrcs142p2_053260. df (Accessed 4-19-2019)

NRCS-USDA. 2014. Inherent factors affecting Soil EC. Guides for Educators. https://www.nrcs.usda.gov/Internet/FSE_DOCUMENTS/nrcs142p2_053260.pdf (Accessed 419-2019)

OSMRE. 2017. Compilation of the Surface Mining Control and Reclamation Act of 1977. Retrieved January 29, 2018, from https://www.osmre.gov/lrg/docs/SMCRA.pdf Pachepsky, Y. and Y. Park. 2015. Saturated Hydraulic Conductivity of US Soils Grouped According to Textural Class and Bulk Density. Soil Sciences Society of American Journal. 79-1094-1100.

Page-Dumroese, D.S., Jurgensen, M.F., Brown, R.E., and G.D. Mroz, 1999. Comparison of methods for determining bulk densities of rocky forest soils. Soil Science Society of America Journal 63: 379-383.

Parisi, V., Menta, C., Gardi, C., Jacomini, C., and E Mozzanica. 2005. Microarthropod communities as a tool to assess soil quality and biodiversity: a new approach in Italy. Agriculture, Ecosystems and Environment 105: 323-333.

Parkin, T.B., Doran, J.W., and E. Franco-Vizcaino. 1996. Field and laboratory tests of soil respiration. Methods for assessing soil quality, SSSA, Madison, WI. 49: 231-245.

Pedersen, T.A., Rogowski, A.S., and R. Pennock, Jr. 1980. Physical characteristics of some minesoils. Soil Sc. Soc. Am. J. 44:321-328.

Pena-Yewtukhiw, E.M., Grove, J.H., Beck, E.G., and J.S. Dinger. 2009. Nitrate contamination of 
a domestic well by an abandoned feedlot: I. Detection and characterization of the nitrate sourcing area. Soil Science 174:56-64.

Pena-Yewtukhiw, E.M., Romano, E.L., Waterland, N.L., and J.H. Grove. 2017. Soil health indicators during transition from row crops to grass-legume sod. Soil Science Society of America Journal. doi:10.2136/sssaj2016.12.0439

Pohl, M., Alig, D., and C. Korner. 2009. Higher plant diversity enhances soil stability in disturbed alpine ecosystems. Plant Soil. 324:91-102.

Riley, J. 2001. Multidisciplinary indicators of impact and change: Key issues for identification and summary. Agriculture, Ecosystems and Environment 87: 245-259.

Roberts, J.A., Daniels, W.L., Bell, J.C., and J.A. Burger. 1988. Early stages of mine soil genesis in a Southwest Virginia spoil litho-sequence. Soil Sci. Soc. Am. J. 52:716-723.

SARE. 2012. Soil Microorganisms. Retrieved December 20, 2018.

https://www.sare.org/Learning-Center/Books/Building-Soils-for-Better-Crops-3 ${ }^{\text {rd }}$ Edition/Text-Version/The-Living-Soil/Soil-Microorganisms

SAS Institute Inc. 2009. SAS/STAT 9.2 User's Guide, Second Edition: Statistics 6th ed. Vol. 2. SAS Institute Inc., Cary, NC, USA.

Sencindiver, J.C. and J.T. Ammons. 2000. Minesoil genesis and classification. Reclamation of Drastically Disturbed Lands, Agronomy Monograph. 41:595-613.

Shrestha, R.K. and R. Lal. 2011. Changes in physical and chemical properties of soil after surface mining and reclamation. Geoderma. 161:168-176.

Schoeneberger, P.J., D.A. Wysocki, E.C. Benham, and Soil Survey Staff. 2012. Field book for describing and sampling soils, Version 3.0. Natural Resources Conservation Service, National Soil Survey Center, Lincoln, NE. 
Setälä H. M., G. Francini, J.A. Allen, N. Hui, A. Jumpponen, and D.J. Kotze. 2016. Vegetation type and age drive changes in soil properties, nitrogen, and carbon sequestration in urban parks under cold climate. Frontiers in Ecology. 4:93. doi: 10.3389/fevo.2016.00093

Skousen, J. and C.E. Zipper. 2014. Post-mining policies and practices in the Eastern USA coal region. International Journal of Coal Science \& Technology 1(2): 135-151.

Smith, J.L. and J.W. Doran. 1996. Measurement and use of $\mathrm{pH}$ and electrical conductivity for oil quality analysis. Methods for Assessing Soil Quality, SSSA 49:169-185.

Sobek, A.A., Skousen, J.G., and S.E. Fisher, Jr. 2000. Chemical and physical properties of overburdens and minesoils. DOI: 10.2134/agronmonogr41.c4.

Soil Health Institute. 2019. National soil health measurements to accelerate agricultural transformation. Retrieved April 14, 2019, https://soilhealthinstitute.org/national-soil healthmeasurements-accelerate-agricultural-transformation/

Soil Quality for Environmental Health. 2011. Retrieved January 4, 2019. http://soilquality.org/indicators/respiration.html

Soil Survey Staff. 1993. Soil survey manual. United States Department of Agriculture. Hnbk no.18. U.S. Gov. Printing Office, Washington, DC.

Sparks, D.L., editor. 1996. Methods of soil analysis: Part 3 chemical methods. SSSA Book Ser. 5. SSSA, Madison, WI. p. 487 and p. 420.

Stoddard, C.S., M. S. Coyne, and J. H. Grove. 1998. Fecal Baterial Survival and Infiltration through a Shallow Agricultural Soil: Timing and Tillage Effects. Journal of Environmental Quality. 27:1516-1523.

Stroo, H.F. and E.M. Jencks. 1982. Enzyme activity and respiration in minesoils. Soil Sci. Soc. Am. J. 46:548-553. 
Thomas, K.A., Sencindiver, J.C., Skousen, J.G., and J.M. Gorman. 2000. Soil horizon development on mountaintop surface mine in southern West Virginia. Retrieved January 8, 2019.https://www.researchgate.net/publication/281378942_Soil_horizon_development_on mountaintop_surface_mine_in_Southern_West_Virginia/citations

Thurman, N.C. and J.C. Sencindiver. 1986. Properties, classification, and interpretations of minesoils at two sites in West Virginia. Soil Science Society of America Journal 50:181185.

Tilman, D.G. 1984. Plant dominance along an experimental nutrient gradient. Ecology. 65(5):1445-1453.

Twum, E.K., and S. Nii-Annang, 2015. Impact of Soil Compaction on Bulk Density and Root Biomass of Quercus petraea L. at Reclaimed Post-Lignite Mining Site in Lusatia, Germany. Applied and Environmental Soil Science 2015(1):1-5. DOI:

$10.1155 / 2015 / 504603$

U.S. Climate Data. 2019. Retrieved April 29, 2019 from https://www.usclimatedata.com/climate/morgantown/west-virginia/united states/uswv0507/2018/12

USDA-NASS, Census of Agriculture. West Virginia State and County Data. 2014. Retrieved February 5, 2018, from https:/www.agcensus.usda.gov/Publications/2012/Full_Report/ Volume_1,_Chapter__State_Level/West_Virginia/wvv1.pdf

USDA-NRCS. Soil Health. Retrieved August 20, 2017, from https://www.nrcs.usda.gov/wps/portal/nrcs/main/soils/health/

USDA-NRCS. Soil Formation and Classification. Retrieved March 28, 2018, from https://www.nrcs.usda.gov/wps/portal/nrcs/detail/soils/edu/?cid=nrcs142p2_054278 
USDA-NRCS. 2001. Soil Quality Test Kit Guide. Retrieved February 11, 2018, from https://www.nrcs.usda.gov/Internet/FSE_DOCUMENTS/nrcs142p2_050956.pdf

USDA. 2019 Saturated hydraulic conductivity relation with soil texture. https://www.nrcs.usda.gov/wps/portal/nrcs/detail/soils/survey/office/ssr10/tr/?cid=nrcs1 4p2_074846. Accessed 4/19/2019.

Visser, S., Griffiths, C.L., and D. Parkinson. 1983. Effects of mining on the microbiology of a prairie site in Alberta, Canada. Can J Soil Sci 63:177-189.

Whittaker, C.W., M.S. Anderson, and R.F. Reitemeier. 1959. Liming soils, an aid to better farming. USDA Farmers Bul. 2124.

Wick, A.F., Ingram, L.J., and P.D. Stahl. 2009. Aggregate and organic matter dynamics in reclaimed soils as indicated by stable carbon isotopes. Soil Biology and Biochemistry. 41(2):201-209.

Wooding, R.A. 1968. Steady infiltration from a shallow circular pond. Water Resources Research 4(6): 1259-1273.

Woods End Research. 1997. Guide to solvita testing and managing your soil. Woods End Research Laboratory, Inc., Mt. Vernon, ME.

WVGES. 2017. History of West Virginia Mineral Industries - Coal. Retrieved February 4, 2018, from http://www.wvgs.wvnet.edu/www/geology/geoldvco.htm

WVMHST. 2015. Statistical Report and Directory of Mines. Retrieved January 15, 2018, from http://www.wvminesafety.org/PDFs/2015\%20Annual\%20Report\%20-\%20CY.pdf

Yoder, R.E. 1936. A direct method of aggregate analysis of soils and a study of the physical nature of erosion losses. J. Am. Soc. Agron. 28:337-351.

Zak, D.R., Holmes, W.E., White, D.C., Peacock, A.D., and D. Tilman. 2003. Plant diversity, soil 
microbial communities, and ecosystem function: Are there any links? Ecology. 84(8):2042-2050.

Zhang, R. and B.J. Wienhold. 2002. The effect of soil moisture on mineral nitrogen, soil electrical conductivity, and pH. Nutrient Cycling in Agroecosystems. 63:651-254. 


\section{APPENDIX A}

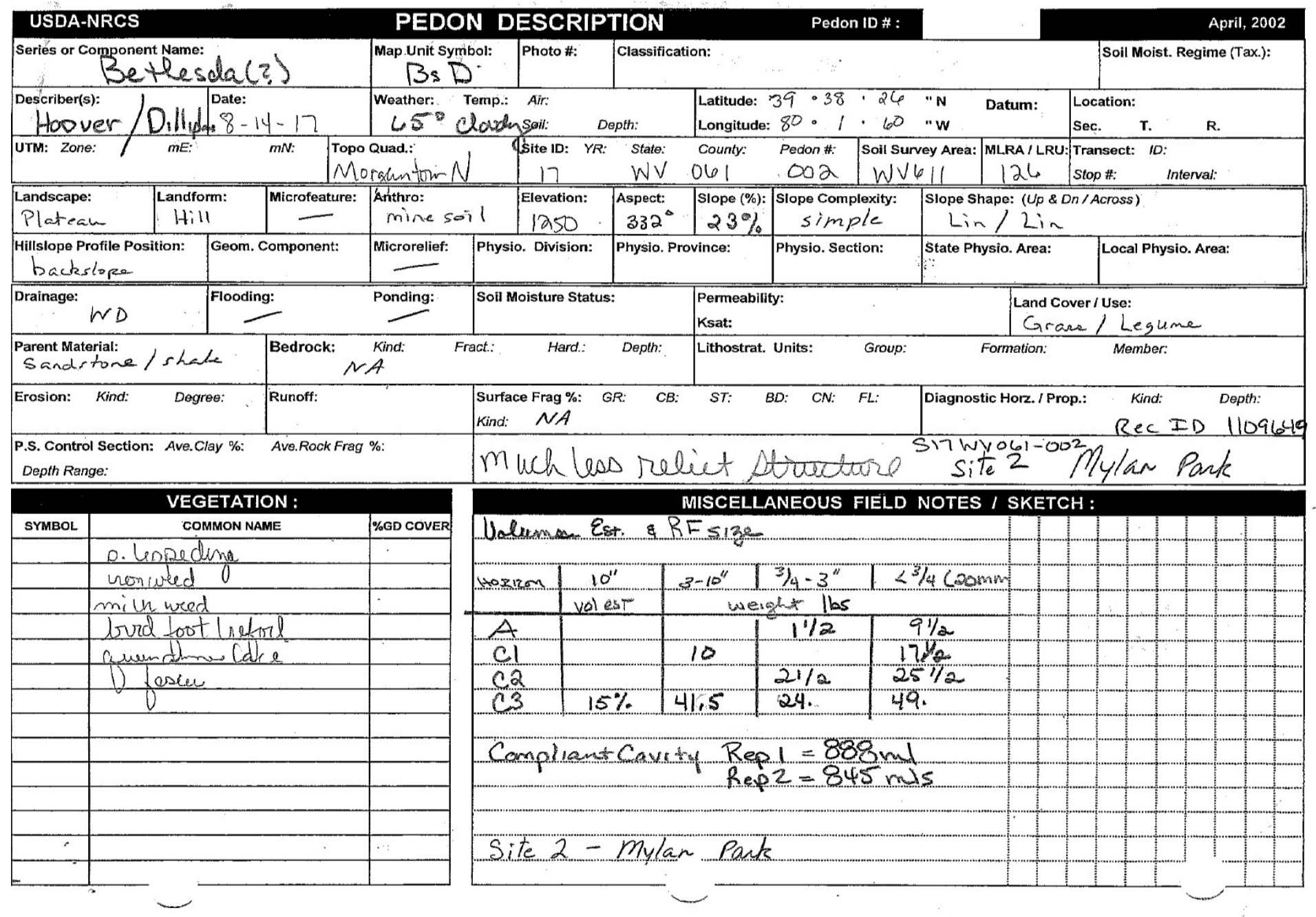

Figure A1a. NRCS pedon description of WV32 mine site. 


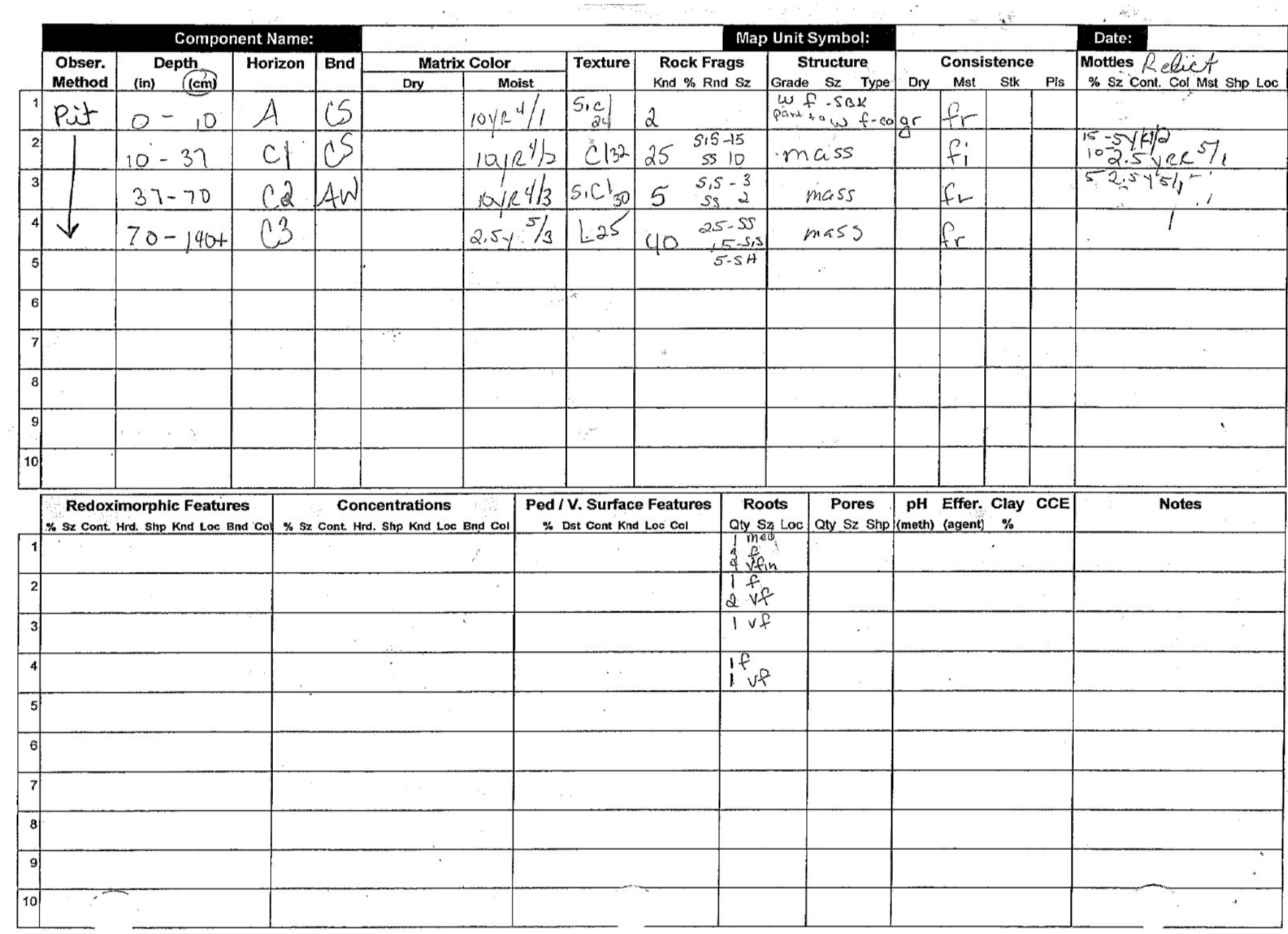

Figure A1b. Continued NRCS pedon description of WV32 mine site. 




Figure A2a. NRCS pedon description of WV16 mine site. 


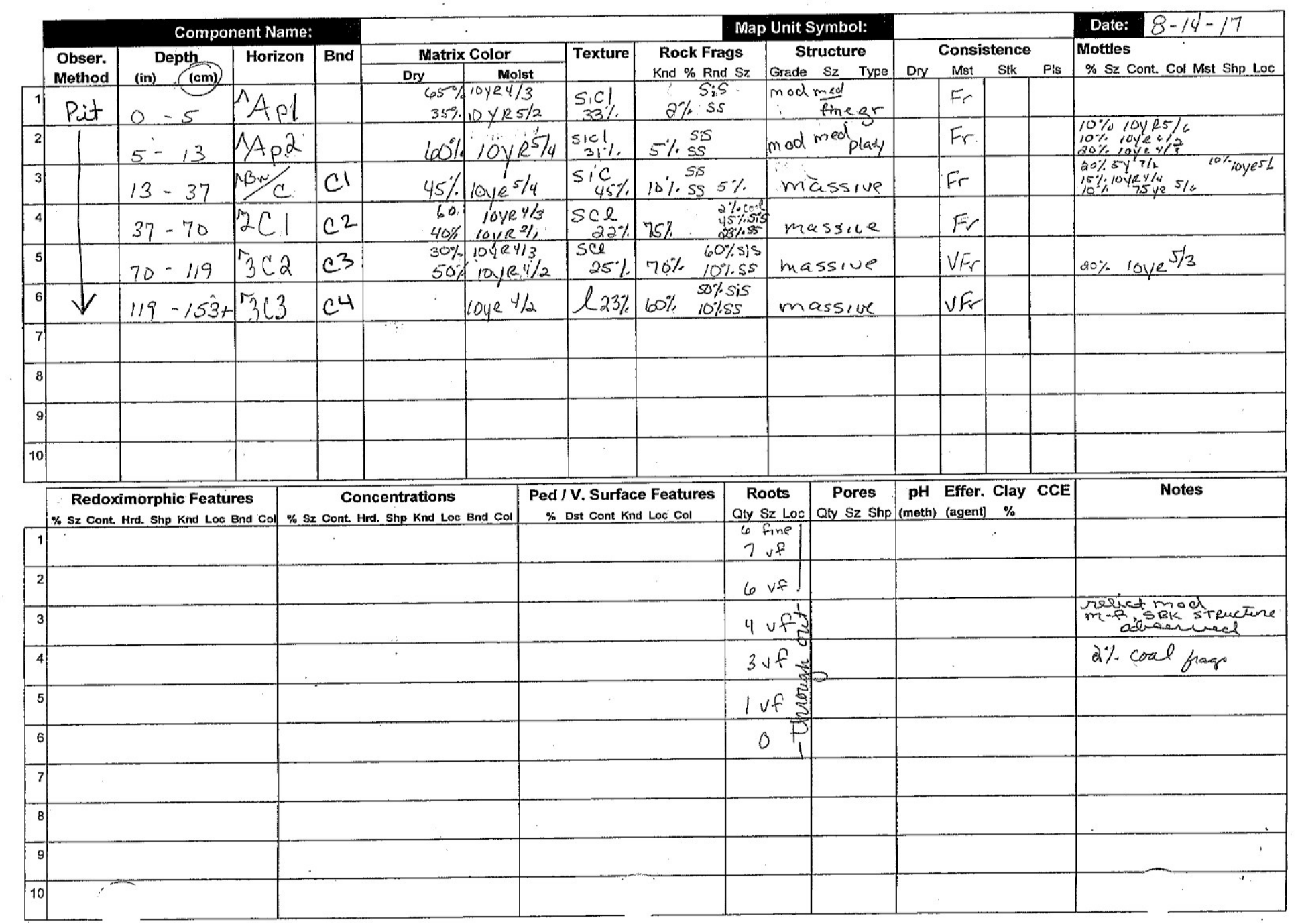

Figure A2b. Continued NRCS pedon description of WV16 mine site. 


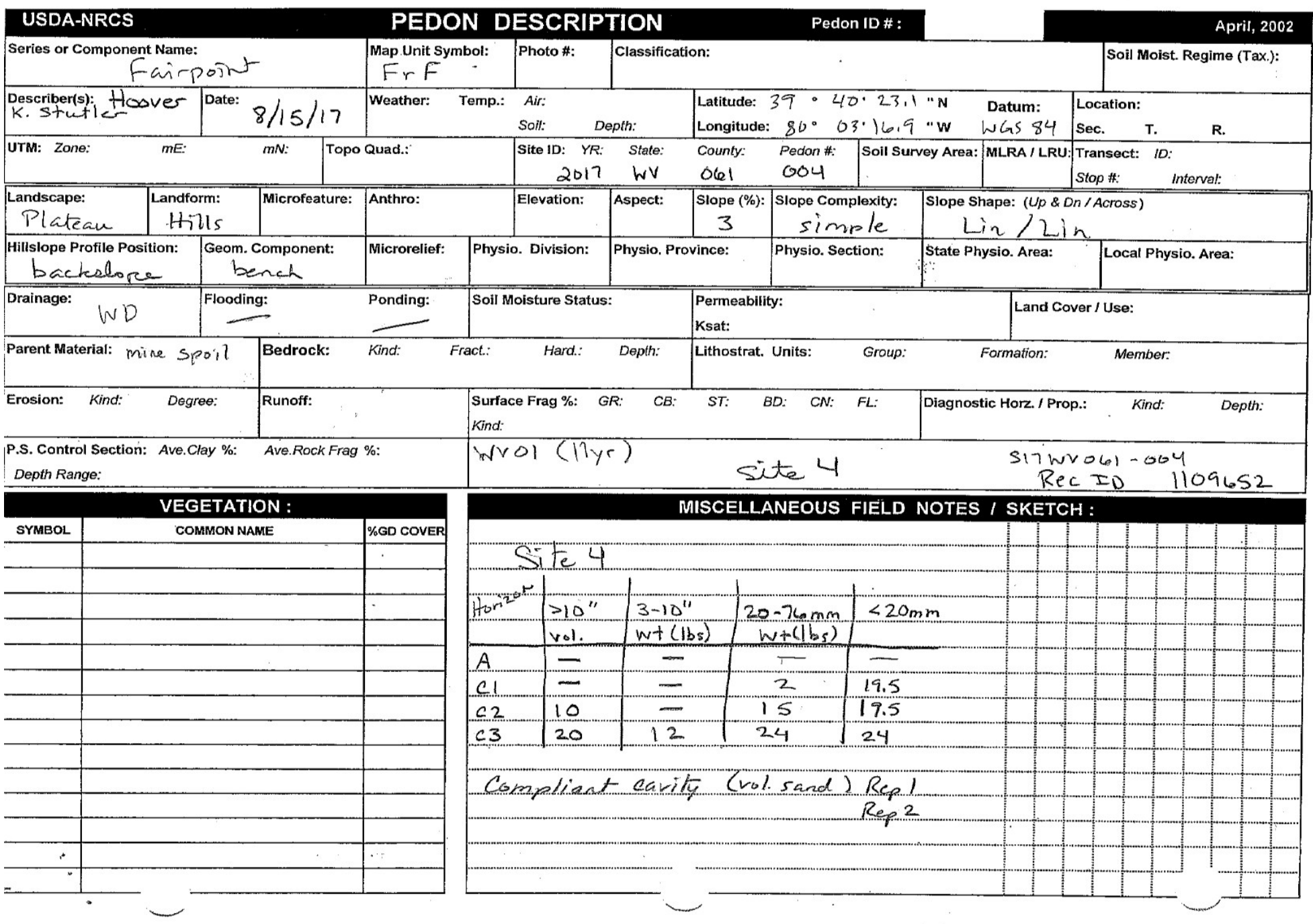

Figure A3a. NRCS pedon description of WV11 mine site. 


\begin{tabular}{|c|c|c|c|c|c|c|c|c|c|c|c|c|c|c|c|}
\hline & \multicolumn{5}{|c|}{ Component Name: } & & & \multicolumn{7}{|c|}{\begin{tabular}{|l|l} 
& Map Unit Symbol: \\
\end{tabular}} & \multirow{3}{*}{$\begin{array}{l}\text { Date: } 8 / 4 / 17 \\
\text { Mottles } \\
\% \text { Sz Cont. Col Mst Shp Loc }\end{array}$} \\
\hline \multirow{2}{*}{\multicolumn{2}{|c|}{$\begin{array}{l}\text { Obser. } \\
\text { Method }\end{array}$}} & Depth & \multirow{2}{*}{\multicolumn{2}{|c|}{\begin{tabular}{l|l} 
Horizon & E
\end{tabular}}} & Bnd & \multicolumn{3}{|c|}{ Matrix Color } & \multirow{2}{*}{ Texture } & \multirow{2}{*}{\multicolumn{2}{|c|}{$\begin{array}{c}\text { Rock Frags } \\
\text { Knd \% Rnd Sz } \\
\end{array}$}} & \multirow{2}{*}{\begin{tabular}{|l|}
\multicolumn{2}{c|}{ Structure } \\
Grade $\mathrm{Sz}$ Type \\
\end{tabular}} & \multirow{2}{*}{\multicolumn{2}{|c|}{ 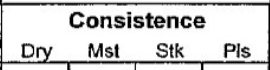 }} & \\
\hline & & (in) (cm) & & & & Dry & Moi & & & & & & & & \\
\hline & pit & $0-3$ & A & & w & & 104 & $24 / 3$ & sil & & & 1 vf $g r$ & fr & & \\
\hline 2 & 1 & $3-38$ & $C_{1}$ & & As & & $10 y R$ & & sil & & & MASS & $f_{i}$ & & $26 \cdot 0^{2 R^{3 / 3}}$ \\
\hline 3 & & $38-60$ & $c$ ? & c & $w$ & & LOYR & $5 / 4$ & si & & & Mass & $u f_{r}$ & & \\
\hline 4 & $T$ & $60-150$ & $c 3$ & & & & $10 \%$ & $4 / 3$ & si & & & MASS & Vifr & & \\
\hline 5 & & & & & & & 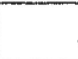 & . & & & & & & & \\
\hline 6 & & & & & & & & & & & & & & & \\
\hline 7 & & & & & & & & & & & & & & & \\
\hline 8 & & & & & & & & & & & & & & & \\
\hline 9 & & & & & & & & & & & & & & & \\
\hline 10. & & & & & & & & & & & & & & & \\
\hline & $\begin{array}{l}\text { Redoxi } \\
\% \text { sz cont } 1\end{array}$ & $\begin{array}{l}\text { norphic Featur } \\
\text { rd. Shp Knd Loc B }\end{array}$ & & $6 \mathrm{Sx}$ con & $\begin{array}{l}\text { Conce } \\
\text { nt Hrd. }\end{array}$ & $\begin{array}{l}\text { ntrations } \\
\text { inp Knd Loc E }\end{array}$ & & $\begin{array}{r}\text { Ped } l \\
\% 0\end{array}$ & $\begin{array}{l}\text { V. Surface } \\
\text { ost cont Kne }\end{array}$ & $\begin{array}{l}\text { e Features } \\
\text { L Loc col }\end{array}$ & $\begin{array}{r}\text { Roots } \\
\text { Qty Sz Lo }\end{array}$ & \begin{tabular}{|c|c|} 
ts & Pores \\
Loc & $\mathrm{Oty}$ Sz Shp \\
\end{tabular} & $\begin{array}{c}\mathrm{pH} \text { Effer. } \\
\text { (meth) (agent) }\end{array}$ & $\begin{array}{l}\text { Clay CCE } \\
\%\end{array}$ & Notes \\
\hline 1 & & & & & & & & & & & $20 v f$ & & & 21 & \\
\hline 2 & & & & & & & & & & & $3 \times f$ & & & 26 & \\
\hline 3 & & & & & & & & & & & Zvf & & & 11 & ocen si $19 \%$ \\
\hline 4 & & & & & & & & & & & $<1, f$ & & & 10 & \\
\hline 5 & & & & & & & & & . & & & & & & \\
\hline 6 & & & & & & & & & & & & & & & \\
\hline 7 & & & & & & & & & & & & & & & \\
\hline 8 & & & & & & & & & & & & & & & \\
\hline 9 & & & & & & & & & & & & & & & $\therefore$ \\
\hline 10 & & & & & & & & & & & & & & & " \\
\hline
\end{tabular}

Figure A3b. Continued NRCS pedon description of WV11 mine site. 


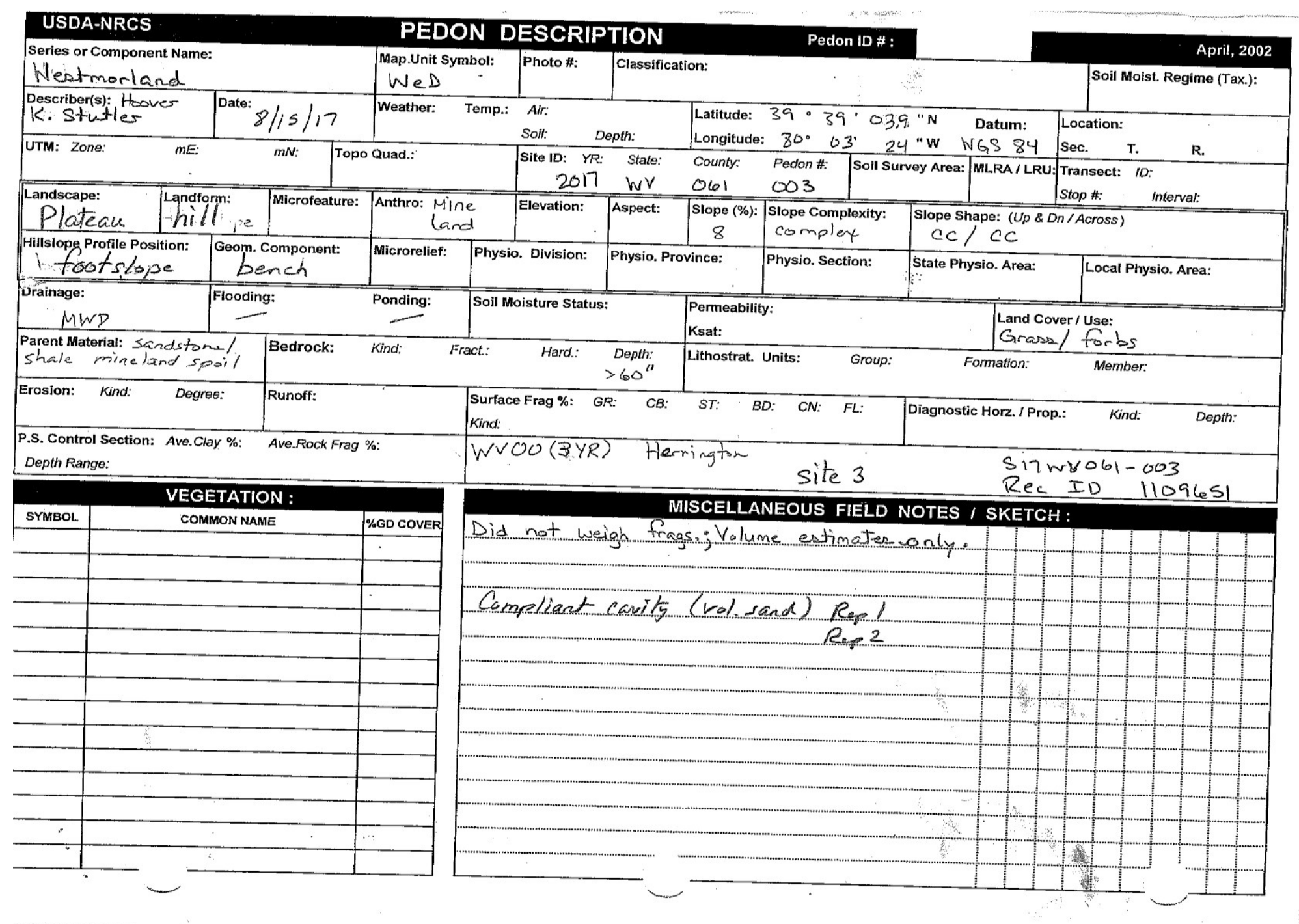

Figure A4a. NRCS pedon description of WV2 mine site. 


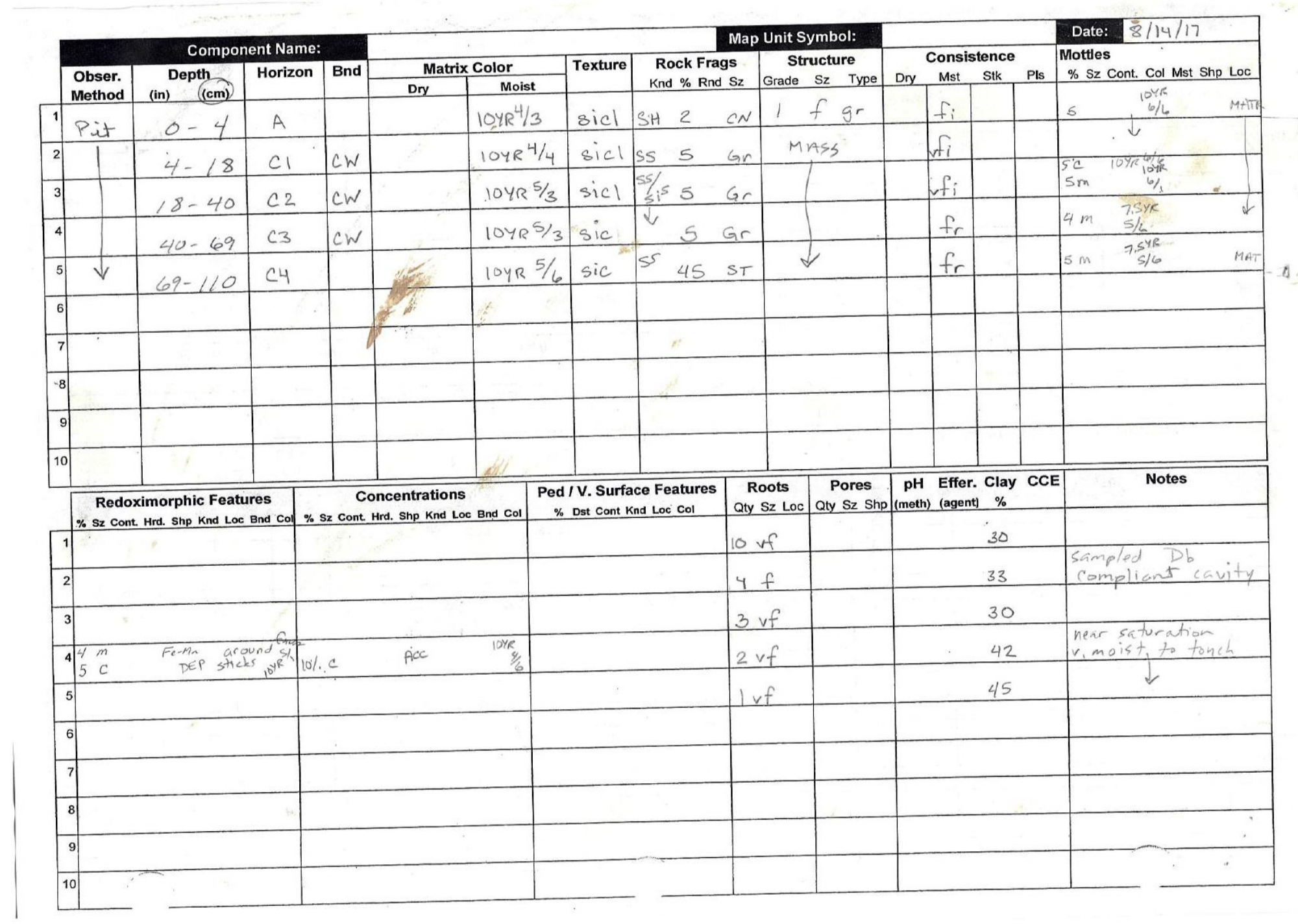

Figure A4b. Continued NRCS pedon description of WV2 mine site. 
Table A1. Experiment I descriptive statistics for all measured indicators across sites.

\begin{tabular}{|c|c|c|c|c|c|}
\hline Indicator & Mean & $\begin{array}{l}\text { Standard } \\
\text { Deviation }\end{array}$ & Mode & Minimum & Maximum \\
\hline Test Kit BD $\left(\mathrm{g} \mathrm{cm}^{-3}\right)$ & 1.29 & 0.16 & 1.25 & 0.91 & 1.61 \\
\hline Standard BD $\left(\mathrm{g} \mathrm{cm}^{-3}\right)$ & 1.46 & 0.20 & & 0.93 & 2.16 \\
\hline Test Kit $K_{s}\left(\mathrm{~cm} \mathrm{~min}^{-}\right)$ & 0.11 & 0.09 & 0.05 & 0.00 & 0.29 \\
\hline Standard $K_{s}\left(\mathrm{~cm} \mathrm{~min}^{-}\right)$ & 0.11 & 0.11 & 0.01 & -0.09 & 0.40 \\
\hline Test Kit pH & 6.44 & 0.73 & 6.10 & 5.10 & 7.60 \\
\hline Standard pH & 6.35 & 0.72 & 6.20 & 5.10 & 7.50 \\
\hline Test Kit EC (dS m) & 0.11 & 0.05 & 0.07 & 0.04 & 0.24 \\
\hline Standard EC (dS m-) & 0.23 & 0.15 & 0.23 & 0.06 & 0.65 \\
\hline $\begin{array}{l}\text { Test Kit Respiration } \\
\text { (lb } \mathrm{CO}_{2} \text { ac day) }\end{array}$ & 40.40 & 16.97 & 20.40 & 20.38 & 90.19 \\
\hline $\begin{array}{l}\text { Standard Respiration (mg kg- } \\
\text { ) }\end{array}$ & 174.74 & 131.59 & 165.00 & 12.00 & 400.00 \\
\hline
\end{tabular}

Table A2. Bulk density (BD in $\mathrm{g} \mathrm{cm}^{-3}$ ) descriptive statistics using the NRCS Soil Quality Test Kit method and standard method for all four sites.

\begin{tabular}{|c|c|c|c|c|c|c|c|c|}
\hline Site & Mean & $\begin{array}{l}\text { Standard } \\
\text { Deviation }\end{array}$ & Minimum & Maximum & Mean & $\begin{array}{l}\text { Standard } \\
\text { Deviation }\end{array}$ & Minimum & Maximum \\
\hline & \multicolumn{4}{|c|}{ Soil Test Kit BD } & \multicolumn{4}{|c|}{ Standard BD } \\
\hline WV2 & 1.37 & 0.11 & 1.25 & 1.57 & 1.53 & 0.15 & 1.33 & 1.82 \\
\hline WV11 & 1.34 & 0.06 & 1.25 & 1.43 & 1.48 & 0.12 & 1.23 & 1.67 \\
\hline WV16 & 1.35 & 0.15 & 1.25 & 1.61 & 1.45 & 0.11 & 1.26 & 1.68 \\
\hline WV32 & 1.12 & 0.17 & 0.91 & 1.43 & 1.37 & 0.32 & 0.93 & 2.16 \\
\hline
\end{tabular}


Table A3. Saturated hydraulic conductivity (Ks in $\left.\mathrm{cm} \mathrm{min}^{-}\right)$descriptive statistics using the NRCS Soil Quality Test Kit method and standard method for all four sites

\begin{tabular}{ccccccccc}
\hline Site & Mean & $\begin{array}{c}\text { Standard } \\
\text { Deviation }\end{array}$ & Minimum & Maximum & Mean & $\begin{array}{c}\text { Standard } \\
\text { Deviation }\end{array}$ & Minimum Maximum \\
\hline WV2 & 0.077 & 0.062 & 0.007 & 0.142 & & 0.073 & 0.111 & 0.009 \\
WV11 & 0.073 & 0.064 & 0.001 & 0.191 & 0.075 & 0.087 & -0.092 & 0.347 \\
WV16 & 0.144 & 0.096 & 0.021 & 0.290 & 0.175 & 0.114 & 0.012 & 0.395 \\
WV32 & 0.175 & 0.104 & 0.069 & 0.288 & 0.099 & 0.105 & -0.037 & 0.316 \\
\hline
\end{tabular}

Table A4. $\mathrm{pH}$ descriptive statistics using the NRCS Soil Quality Test Kit method and standard method for all four sites.

\begin{tabular}{|c|c|c|c|c|c|c|c|c|}
\hline Site & Mean & $\begin{array}{l}\text { Standard } \\
\text { Deviation }\end{array}$ & Minimum & Maximum & Mean & $\begin{array}{l}\text { Standard } \\
\text { Deviation }\end{array}$ & Minimum & Maximum \\
\hline & \multicolumn{4}{|c|}{ Soil Test Kit $\mathrm{pH}$} & \multicolumn{4}{|c|}{ Standard $\mathrm{pH}$} \\
\hline WV2 & 6.03 & 0.42 & 5.20 & 6.50 & 6.05 & 0.51 & 5.20 & 7.00 \\
\hline WV11 & 5.81 & 0.42 & 5.10 & 6.50 & 5.82 & 0.46 & 5.10 & 6.60 \\
\hline WV16 & 6.53 & 0.56 & 5.80 & 7.10 & 6.26 & 0.58 & 5.40 & 7.00 \\
\hline WV32 & 7.34 & 0.26 & 6.90 & 7.60 & 7.27 & 0.25 & 6.70 & 7.50 \\
\hline
\end{tabular}

Table A5. Electrical conductivity (EC in $\mathrm{dS} \mathrm{m}^{-}$) descriptive statistics using the NRCS Soil Quality Test Kit method and standard method for all four sites.

\begin{tabular}{|c|c|c|c|c|c|c|c|c|}
\hline Site & Mean & $\begin{array}{l}\text { Standard } \\
\text { Deviation }\end{array}$ & Minimum & Maximum & Mean & $\begin{array}{l}\text { Standard } \\
\text { Deviation }\end{array}$ & Minimum & Maximum \\
\hline & \multicolumn{4}{|c|}{ Soil Test Kit EC } & \multicolumn{4}{|c|}{ Standard EC } \\
\hline WV2 & 0.089 & 0.037 & 0.040 & 0.130 & 0.201 & 0.083 & 0.110 & 0.376 \\
\hline WV11 & 0.081 & 0.025 & 0.060 & 0.140 & 0.097 & 0.024 & 0.060 & 0.125 \\
\hline WV16 & 0.128 & 0.042 & 0.050 & 0.180 & 0.169 & 0.066 & 0.100 & 0.311 \\
\hline WV32 & 0.154 & 0.050 & 0.110 & 0.240 & 0.438 & 0.125 & 0.324 & 0.646 \\
\hline
\end{tabular}


Table A6. Respiration descriptive statistics using the NRCS Soil Quality Test Kit method and standard method for all four sites.

\begin{tabular}{cccccccccc}
\hline Site & Mean & $\begin{array}{c}\text { Standard } \\
\text { Deviation }\end{array}$ & Minimum & Maximum & & Mean $\begin{array}{c}\text { Standard } \\
\text { Deviation }\end{array}$ & Minimum Maximum \\
\hline WV2 & 41.93 & 12.28 & 26.76 & 58.58 & & & \multicolumn{3}{c}{ Standard Respiration $(\mathrm{mg} / \mathrm{kg})$} \\
\cline { 2 - 7 } WV11 & 25.94 & 6.06 & 20.38 & 38.67 & & 77.20 & 49.55 & 12.00 & 165.00 \\
WV16 & 48.39 & 18.50 & 27.12 & 89.77 & & 167.25 & 130.37 & 50.00 & 400.00 \\
WV32 & 45.36 & 19.63 & 27.04 & 90.19 & & 240.00 & 142.48 & 70.00 & 400.00 \\
\hline
\end{tabular}

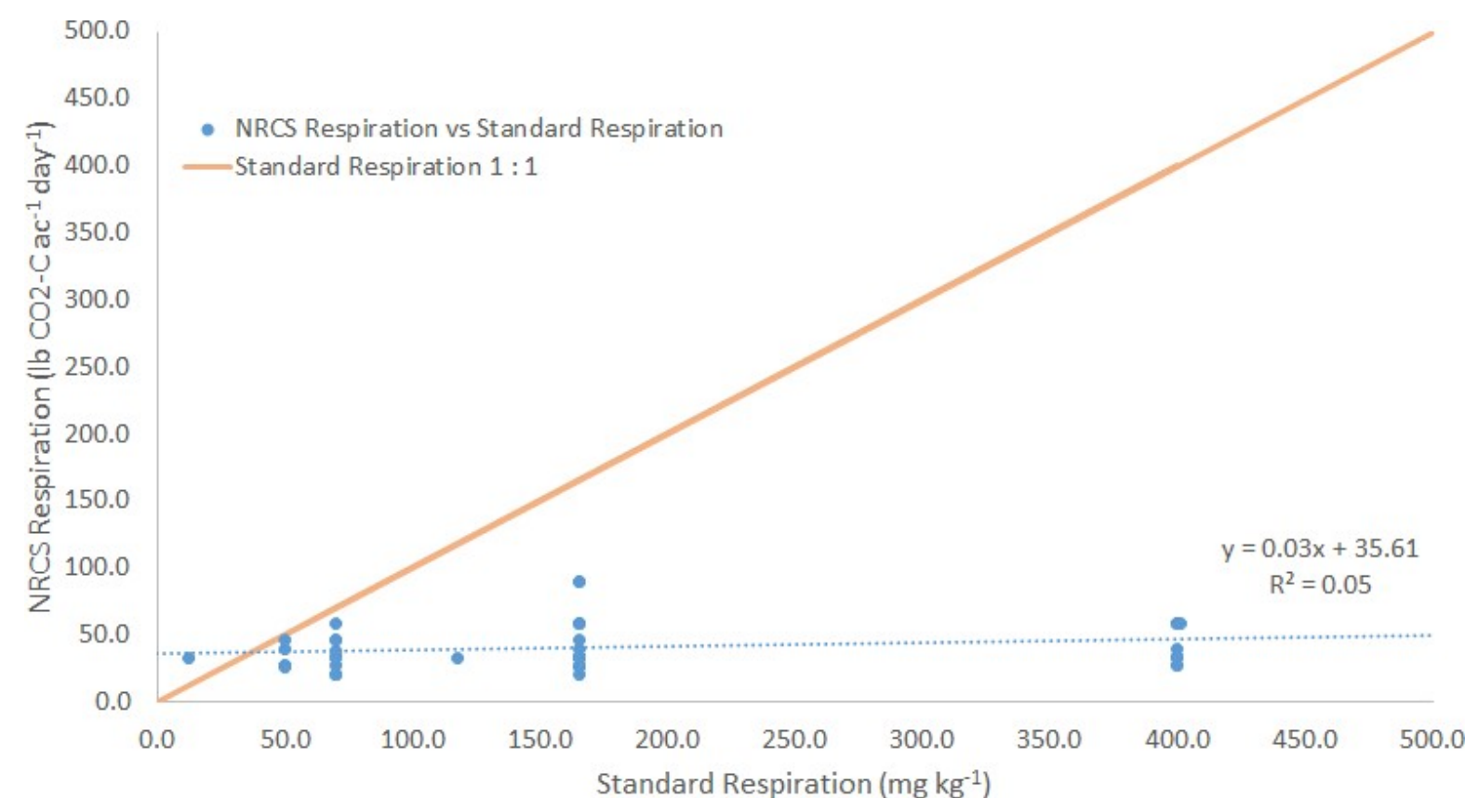

Figure A5. Overall (all sites) comparison of respiration obtained with the Standard and NRCS methods. In the overall site comparison respiration methods, a 1:1 linear regression was used to determine whether there was a deviation of slope between the test kit and standard methods and the 1:1 linear regression of the standard method. Figure 14 shows the linear relationship between the two methods and the 1:1 linear regression 


\section{APPENDIX B}

Table B1. Experiment II physical property descriptive statistics among all sites

\begin{tabular}{|c|c|c|c|c|c|c|}
\hline Indicator & Mean & $\begin{array}{l}\text { Standard } \\
\text { Deviation }\end{array}$ & $\begin{array}{c}\text { Standard } \\
\text { Error }\end{array}$ & Mode & Minimum & Maximum \\
\hline Corrected BD $\left(\mathrm{g} \mathrm{cm}^{-3}\right)$ & 1.481 & 0.145 & 0.012 & 1.450 & 1.120 & 1.9 \\
\hline Percent Fines & 90.459 & 3.855 & 0.315 & 89.300 & 73.100 & 97 \\
\hline Clay $\left(\mathrm{mg} \mathrm{kg}^{-1}\right)$ & 264.490 & 31.695 & 2.588 & 240.400 & 119.700 & 341.7 \\
\hline Dry Aggregate MWD & 33.368 & 6.179 & 0.505 & 28.564 & 16.909 & 45.945 \\
\hline Dry Aggregate GMD & 19.016 & 5.042 & 0.412 & 14.759 & 7.655 & 31.889 \\
\hline Dry Aggregate logGSD & 1.321 & 0.084 & 0.007 & 1.269 & 1.051 & 1.703 \\
\hline Wet Aggregate MWD & 5.900 & 0.319 & 0.026 & 5.707 & 4.854 & 6.302 \\
\hline Wet Aggregate GMD & 5.555 & 0.473 & 0.039 & 5.943 & 4.098 & 6.186 \\
\hline
\end{tabular}


Table B2. Experiment II chemical property descriptive statistics among all sites

\begin{tabular}{|c|c|c|c|c|c|c|}
\hline Indicator & Mean & $\begin{array}{l}\text { Standard } \\
\text { Deviation }\end{array}$ & $\begin{array}{c}\text { Standard } \\
\text { Error }\end{array}$ & Mode & Minimum & Maximum \\
\hline OM $\left(\mathrm{mg} \mathrm{kg}^{-1}\right)$ & 50.017 & 10.477 & 0.855 & 38.600 & 29.900 & 82 \\
\hline pH & 6.014 & 0.605 & 0.049 & 5.600 & 5.010 & 7.63 \\
\hline Al $\left(\mathrm{mg} \mathrm{kg} \mathbf{~}^{-1}\right)$ & 510.242 & 125.277 & 10.229 & 512.100 & 128.400 & 1095 \\
\hline Ca $\left(\mathrm{mg} \mathrm{kg}^{-1}\right)$ & 1436.780 & 784.613 & 64.063 & 1108.000 & 407.700 & 5567 \\
\hline $\mathrm{Fe}\left(\mathrm{mg} \mathrm{kg} \mathrm{kg}^{-1}\right)$ & 76.850 & 27.801 & 2.270 & 57.420 & 36.820 & 182.9 \\
\hline K (mg kg-1) & 102.147 & 26.977 & 2.203 & 69.300 & 45.310 & 191.42 \\
\hline $\operatorname{Mg}\left(\mathrm{mg} \mathrm{kg}^{-1}\right)$ & 151.924 & 48.252 & 3.940 & 108.900 & 64.750 & 282.04 \\
\hline $\mathrm{Na}\left(\mathrm{mg} \mathrm{kg} \mathbf{~}^{-1}\right)$ & 73.763 & 18.214 & 1.487 & 71.470 & 37.670 & 170.9 \\
\hline $\mathbf{P}\left(\mathbf{m g ~ k g} \mathbf{~}^{-1}\right)$ & 6.170 & 4.457 & 0.364 & 3.600 & 1.770 & 39.84 \\
\hline $\mathrm{Zn}\left(\mathrm{mg} \mathrm{kg}^{-1}\right)$ & 1.558 & 0.674 & 0.055 & 1.220 & 0.680 & 4.56 \\
\hline
\end{tabular}


Table B3. Experiment II vegetation survey descriptive statistics among all sites

\begin{tabular}{|c|c|c|c|c|c|c|}
\hline Indicator & Mean & $\begin{array}{l}\text { Standard } \\
\text { Deviation }\end{array}$ & $\begin{array}{c}\text { Standard } \\
\text { Error }\end{array}$ & Mode & Minimum & Maximum \\
\hline Surface Cover 2017 & 0.999 & 0.005 & 0.000 & 1.000 & 0.960 & 1 \\
\hline Dead Material_2017 & 0.107 & 0.071 & 0.006 & 0.040 & 0.000 & 0.51 \\
\hline Moss 2017 & 0.008 & 0.004 & 0.000 & 0.010 & 0.000 & 0.01 \\
\hline Canopy Cover 2017 & 0.904 & 0.102 & 0.008 & 1.000 & 0.250 & 1 \\
\hline Legumes 2017 & 0.359 & 0.164 & 0.013 & 0.260 & 0.000 & 0.82 \\
\hline Forbs 2017 & 0.220 & 0.160 & 0.013 & 0.000 & 0.000 & 0.56 \\
\hline Grass 2017 & 0.325 & 0.210 & 0.017 & 0.260 & 0.010 & 0.95 \\
\hline Moss Only 2017 & 0.016 & 0.060 & 0.005 & 0.000 & -0.060 & 0.44 \\
\hline Bare Soil 2017 & 0.001 & 0.005 & 0.000 & 0.000 & 0.000 & 0.04 \\
\hline Surface Cover 2018 & 0.993 & 0.082 & 0.007 & 1.000 & 0.000 & 1 \\
\hline Dead Material 2018 & 0.068 & 0.121 & 0.010 & 0.000 & 0.000 & 0.84 \\
\hline Moss 2018 & 0.008 & 0.004 & 0.000 & 0.010 & 0.000 & 0.01 \\
\hline Canopy Cover 2018 & 0.893 & 0.168 & 0.014 & 1.000 & 0.000 & 1 \\
\hline Legumes 2018 & 0.222 & 0.175 & 0.014 & 0.170 & 0.000 & 0.81 \\
\hline Forbs 2018 & 0.227 & 0.197 & 0.016 & 0.000 & 0.000 & 0.82 \\
\hline Grass_2018 & 0.472 & 0.209 & 0.017 & 0.490 & 0.000 & 0.94 \\
\hline Moss Ō Only 2018 & 0.006 & 0.019 & 0.002 & 0.000 & 0.000 & 0.1 \\
\hline Bare Soil 2018 & 0.007 & 0.082 & 0.007 & 0.000 & 0.000 & 1 \\
\hline
\end{tabular}


Table B4. Experiment II physical properties descriptive statistics site WV2

\begin{tabular}{|c|c|c|c|c|c|c|}
\hline Indicators & Mean & $\begin{array}{l}\text { Standard } \\
\text { Deviation }\end{array}$ & $\begin{array}{c}\text { Standard } \\
\text { Error }\end{array}$ & Mode & Minimum & Maximum \\
\hline Uncorrected BD $\left(\mathrm{g} \mathrm{cm}^{-3}\right)$ & 1.582 & 0.133 & 0.019 & 1.610 & 1.290 & 1.880 \\
\hline Corrected BD $\left(\mathrm{g} \mathrm{cm}^{-3}\right)$ & 1.511 & 0.146 & 0.021 & 1.380 & 1.170 & 1.820 \\
\hline Percent Rock & 10.274 & 4.220 & 0.597 & 5.900 & 3.300 & 26.900 \\
\hline Percent Fines & 89.726 & 4.220 & 0.597 & 88.200 & 73.100 & 96.700 \\
\hline Clay $\left(\mathrm{mg} \mathrm{kg}^{-1}\right)$ & 280.604 & 25.930 & 3.667 & 291.000 & 216.900 & 341.700 \\
\hline Sand $\left(\mathrm{mg} \mathrm{kg}^{-1}\right)$ & 197.610 & 29.195 & 4.129 & . & 131.700 & 279.200 \\
\hline Silt $\left(\mathrm{mg} \mathrm{kg}^{-1}\right)$ & 521.786 & 29.704 & 4.201 & 517.900 & 470.100 & 619.700 \\
\hline Dry Aggregate MWD & 36.056 & 5.239 & 0.741 & . & 23.511 & 44.579 \\
\hline Dry Aggregate GMD & 20.710 & 4.795 & 0.678 & . & 11.154 & 29.347 \\
\hline Dry Aggregate logGSD & 1.357 & 0.096 & 0.014 & 1.269 & 1.227 & 1.703 \\
\hline Wet Aggregate MWD & 5.746 & 0.277 & 0.039 & . & 5.164 & 6.219 \\
\hline Wet Aggregate GMD & 5.319 & 0.418 & 0.059 & 5.297 & 4.545 & 6.048 \\
\hline Wet Aggregate logGSD & 0.501 & 0.116 & 0.016 & 0.475 & 0.321 & 0.928 \\
\hline
\end{tabular}


Table B5. Experiment II chemical properties descriptive statistics site WV2

\begin{tabular}{|c|c|c|c|c|c|c|}
\hline Indicator & Mean & $\begin{array}{l}\text { Standard } \\
\text { Deviation }\end{array}$ & $\begin{array}{c}\text { Standard } \\
\text { Error }\end{array}$ & Mode & Minimum & Maximum \\
\hline OM (mg kg $\left.{ }^{-1}\right)$ & 52.776 & 10.502 & 1.485 & 38.100 & 35.200 & 80.700 \\
\hline pH & 6.050 & 0.552 & 0.078 & 5.600 & 5.090 & 7.240 \\
\hline $\mathrm{Al}\left(\mathrm{mg} \mathrm{kg}^{-1}\right)$ & 490.090 & 112.837 & 15.958 & 512.100 & 128.400 & 675.200 \\
\hline $\mathrm{Ca}\left(\mathrm{mg} \mathrm{kg}^{-1}\right)$ & 1575.190 & 852.883 & 120.616 & . & 694.400 & 4728.940 \\
\hline Fe $\left(m g k^{-1}\right)$ & 87.612 & 22.663 & 3.205 & . & 57.420 & 175.800 \\
\hline $\mathrm{K}\left(\mathrm{mg} \mathrm{kg}^{-1}\right)$ & 104.068 & 23.945 & 3.386 & . & 58.390 & 147.300 \\
\hline $\operatorname{Mg}\left(\mathrm{mg} \mathrm{kg}^{-1}\right)$ & 201.482 & 42.898 & 6.067 & . & 124.600 & 282.040 \\
\hline $\left.\mathrm{Na}(\mathrm{mg} \mathrm{kg})^{-1}\right)$ & 71.263 & 11.606 & 1.641 & . & 46.750 & 112.420 \\
\hline$P\left(\mathrm{mg} \mathrm{kg}^{-1}\right)$ & 8.888 & 6.383 & 0.903 & 5.500 & 2.350 & 39.840 \\
\hline $\mathrm{Zn}\left(\mathrm{mg} \mathrm{kg}{ }^{-1}\right)$ & 1.972 & 0.706 & 0.100 & 1.270 & 0.910 & 4.560 \\
\hline
\end{tabular}


Table B6. Experiment II \% vegetation descriptive statistics WV2

\begin{tabular}{|c|c|c|c|c|c|c|}
\hline Indicator & Mean & $\begin{array}{l}\text { Standard } \\
\text { Deviation }\end{array}$ & $\begin{array}{c}\text { Standard } \\
\text { Error }\end{array}$ & Mode & Minimum & Maximum \\
\hline Surface Cover 2017 & 99.74 & 0.80 & 0.11 & 100.00 & 96.00 & 100.00 \\
\hline Dead Material_2017 & 10.18 & 5.64 & 0.80 & 4.00 & 2.00 & 29.00 \\
\hline Moss 2017 & 1.00 & 0.00 & 0.00 & 1.00 & 1.00 & 1.00 \\
\hline Canopy Cover 2017 & 89.54 & 5.62 & 0.79 & 87.00 & 71.00 & 98.00 \\
\hline Legumes_2017 & 36.26 & 13.39 & 1.89 & 47.00 & 0.00 & 67.00 \\
\hline Forbs 2017 & 36.66 & 8.65 & 1.22 & 42.00 & 17.00 & 56.00 \\
\hline Grass 2017 & 16.70 & 10.08 & 1.43 & 14.00 & 1.00 & 41.00 \\
\hline Moss Only 2017 & 0.08 & 0.44 & 0.06 & 0.00 & 0.00 & 3.00 \\
\hline Bare Soil 2017 & 0.26 & 0.80 & 0.11 & 0.00 & 0.00 & 4.00 \\
\hline Surface Cover 2018 & 99.96 & 0.28 & 0.04 & 100.00 & 98.00 & 100.00 \\
\hline Dead Material 2018 & 5.62 & 7.28 & 1.03 & 0.00 & 0.00 & 35.00 \\
\hline Moss 2018 & 1.00 & 0.00 & 0.00 & 1.00 & 1.00 & 1.00 \\
\hline Canopy Cover 2018 & 90.48 & 8.56 & 1.21 & 100.00 & 65.00 & 100.00 \\
\hline Legumes 2018 & 13.58 & 7.59 & 1.07 & 15.00 & 2.00 & 34.00 \\
\hline Forbs 2018 & 35.48 & 16.55 & 2.34 & 24.00 & 12.00 & 74.00 \\
\hline Grass 2018 & 45.12 & 19.72 & 2.79 & 21.00 & 6.00 & 85.00 \\
\hline Moss Only 2018 & 0.02 & 0.14 & 0.02 & 0.00 & 0.00 & 1.00 \\
\hline Bare Soil 2018 & 0.04 & 0.28 & 0.04 & 0.00 & 0.00 & 2.00 \\
\hline
\end{tabular}


Table B7. Experiment II physical properties descriptive statistics site WV11

\begin{tabular}{|c|c|c|c|c|c|c|}
\hline Indicator & Mean & $\begin{array}{l}\text { Standard } \\
\text { Deviation }\end{array}$ & $\begin{array}{l}\text { Standard } \\
\text { Error }\end{array}$ & Mode & Minimum & Maximum \\
\hline Uncorrected BD $\left(\mathrm{g} \mathrm{cm}^{-3}\right)$ & 1.526 & 0.163 & 0.023 & 1.510 & 1.160 & 1.960 \\
\hline Corrected BD $\left(\mathrm{g} \mathrm{cm}^{-3}\right)$ & 1.472 & 0.166 & 0.024 & 1.470 & 1.120 & 1.900 \\
\hline Percent Rock & 8.084 & 2.804 & 0.396 & 6.700 & 3.700 & 17.100 \\
\hline Percent Fines & 91.916 & 2.804 & 0.396 & 93.300 & 82.900 & 96.300 \\
\hline Clay $\left(\mathrm{mg} \mathrm{kg}^{-1}\right)$ & 263.176 & 14.989 & 2.120 & . & 237.700 & 320.200 \\
\hline Sand $\left(\mathrm{mg} \mathrm{kg}^{-1}\right)$ & 256.944 & 25.140 & 3.555 & 255.000 & 153.500 & 294.900 \\
\hline Silt (mg kg-1) & 479.884 & 14.061 & 1.989 & . & 454.300 & 526.300 \\
\hline Dry Aggregate MWD & 32.929 & 7.053 & 0.997 & . & 16.909 & 45.945 \\
\hline Dry Aggregate GMD & 19.221 & 5.632 & 0.797 & . & 10.097 & 31.889 \\
\hline Dry Aggregate logGSD & 1.282 & 0.068 & 0.010 & 1.241 & 1.051 & 1.445 \\
\hline Wet Aggregate MWD & 5.843 & 0.374 & 0.053 & 6.102 & 4.854 & 6.270 \\
\hline Wet Aggregate GMD & 5.469 & 0.537 & 0.076 & 5.950 & 4.098 & 6.120 \\
\hline Wet Aggregate logGSD & 0.457 & 0.126 & 0.018 & 0.383 & 0.290 & 0.851 \\
\hline
\end{tabular}


Table B8. Experiment II chemical properties descriptive statistics WV11

\begin{tabular}{|c|c|c|c|c|c|c|}
\hline Indicator & Mean & $\begin{array}{l}\text { Standard } \\
\text { Deviation }\end{array}$ & $\begin{array}{c}\text { Standard } \\
\text { Error }\end{array}$ & Mode & Minimum & Maximum \\
\hline OM (mg kg-1) & 42.190 & 6.138 & 0.868 & 38.600 & 29.900 & 57.500 \\
\hline pH & 5.838 & 0.413 & 0.058 & 5.750 & 5.080 & 6.910 \\
\hline $\mathrm{Al}\left(\mathrm{mg} \mathrm{kg}^{-1}\right)$ & 499.620 & 59.555 & 8.422 & 526.600 & 383.400 & 631.200 \\
\hline $\mathrm{Ca}\left(\mathrm{mg} \mathrm{kg}{ }^{-1}\right)$ & 982.480 & 244.480 & 34.575 & . & 407.700 & 1544.150 \\
\hline $\mathrm{Fe}\left(\mathrm{mg} \mathrm{kg}^{-1}\right)$ & 59.492 & 7.238 & 1.024 & . & 43.410 & 78.030 \\
\hline $\mathrm{K}\left(\mathrm{mg} \mathrm{kg}^{-1}\right)$ & 104.598 & 20.521 & 2.902 & . & 69.300 & 152.700 \\
\hline $\operatorname{Mg}\left(\mathrm{mg} \mathrm{kg}^{-1}\right)$ & 119.625 & 24.933 & 3.526 & 111.800 & 70.380 & 226.630 \\
\hline $\mathrm{Na}\left(\mathrm{mg} \mathrm{kg}^{-1}\right)$ & 70.623 & 17.683 & 2.501 & . & 37.670 & 170.900 \\
\hline$P\left(\mathrm{mg} \mathrm{kg}^{-1}\right)$ & 4.307 & 1.673 & 0.237 & 4.230 & 1.950 & 12.440 \\
\hline $\mathrm{Zn}\left(\mathrm{mg} \mathrm{kg} \mathrm{kg}^{-1}\right)$ & 1.058 & 0.239 & 0.034 & 0.970 & 0.680 & 1.710 \\
\hline
\end{tabular}


Table B9. Experiment II \% vegetation descriptive statistics WV11

\begin{tabular}{|c|c|c|c|c|c|c|}
\hline Indicator & Mean & $\begin{array}{l}\text { Standard } \\
\text { Deviation }\end{array}$ & $\begin{array}{c}\text { Standard } \\
\text { Error }\end{array}$ & Mode & Minimum & Maximum \\
\hline Surface Cover 2017 & 100.00 & 0.00 & 0.00 & 100.00 & 100.00 & 100.00 \\
\hline Dead Material 2017 & 10.82 & 8.88 & 1.26 & 4.00 & 0.00 & 51.00 \\
\hline Moss 2017 & 0.58 & 0.50 & 0.07 & 1.00 & 0.00 & 1.00 \\
\hline Canopy Cover 2017 & 95.34 & 10.59 & 1.50 & 100.00 & 42.00 & 100.00 \\
\hline Legumes_2017 & 34.28 & 18.96 & 2.68 & 29.00 & 5.00 & 82.00 \\
\hline Forbs 2017 & 10.82 & 12.46 & 1.76 & 0.00 & 0.00 & 49.00 \\
\hline Grass 2017 & 50.14 & 20.75 & 2.93 & 46.00 & 9.00 & 95.00 \\
\hline Moss Only 2017 & 2.16 & 7.82 & 1.11 & 0.00 & 0.00 & 44.00 \\
\hline Bare Soil 2017 & 0.00 & 0.00 & 0.00 & 0.00 & 0.00 & 0.00 \\
\hline Surface Cover 2018 & 100.00 & 0.00 & 0.00 & 100.00 & 100.00 & 100.00 \\
\hline Dead Material 2018 & 7.14 & 11.07 & 1.57 & 0.00 & 0.00 & 66.00 \\
\hline Moss 2018 & 0.72 & 0.45 & 0.06 & 1.00 & 0.00 & 1.00 \\
\hline Canopy Cover 2018 & 92.86 & 11.07 & 1.57 & 100.00 & 34.00 & 100.00 \\
\hline Legumes_2018 & 29.06 & 22.08 & 3.12 & 7.00 & 2.00 & 79.00 \\
\hline Forbs 2018 & 14.54 & 17.90 & 2.53 & 0.00 & 0.00 & 82.00 \\
\hline Grass 2018 & 49.88 & 22.13 & 3.13 & 51.00 & 11.00 & 94.00 \\
\hline Moss Only 2018 & 0.02 & 0.14 & 0.02 & 0.00 & 0.00 & 1.00 \\
\hline Bare Soil 2018 & 0.00 & 0.00 & 0.00 & 0.00 & 0.00 & 0.00 \\
\hline
\end{tabular}


Table B10. Experiment II physical properties descriptive statistics site WV16

\begin{tabular}{|c|c|c|c|c|c|c|}
\hline Indicator & Mean & $\begin{array}{l}\text { Standard } \\
\text { Deviation }\end{array}$ & $\begin{array}{c}\text { Standard } \\
\text { Error }\end{array}$ & Mode & Minimum & Maximum \\
\hline Uncorrected BD $\left(\mathrm{g} \mathrm{cm}^{-3}\right)$ & 1.543 & 0.130 & 0.018 & 1.500 & 1.280 & 1.900 \\
\hline Corrected BD $\left(\mathrm{g} \mathrm{cm}^{-3}\right)$ & 1.461 & 0.118 & 0.017 & 1.450 & 1.210 & 1.790 \\
\hline Percent Rock & 10.264 & 4.034 & 0.571 & 6.300 & 3.000 & 25.100 \\
\hline Percent Fines & 89.736 & 4.034 & 0.571 & 88.600 & 74.900 & 97.000 \\
\hline Clay $\left(\mathrm{mg} \mathrm{kg}^{-1}\right)$ & 249.690 & 40.835 & 5.775 & . & 119.700 & 325.700 \\
\hline Sand $\left(\mathrm{mg} \mathrm{kg}^{-1}\right)$ & 284.116 & 85.106 & 12.036 & . & 195.700 & 586.800 \\
\hline Silt $\left(\mathrm{mg} \mathrm{kg}^{-1}\right)$ & 466.196 & 53.138 & 7.515 & . & 293.500 & 541.500 \\
\hline Dry Aggregate MWD & 31.119 & 5.115 & 0.723 & . & 17.663 & 41.973 \\
\hline Dry Aggregate GMD & 17.117 & 3.994 & 0.565 & 18.013 & 7.655 & 27.517 \\
\hline Dry Aggregate logGSD & 1.324 & 0.070 & 0.010 & 1.323 & 1.196 & 1.531 \\
\hline Wet Aggregate MWD & 6.113 & 0.140 & 0.020 & 6.139 & 5.402 & 6.302 \\
\hline Wet Aggregate GMD & 5.877 & 0.216 & 0.031 & 5.943 & 4.887 & 6.186 \\
\hline Wet Aggregate logGSD & 0.367 & 0.081 & 0.011 & 0.329 & 0.260 & 0.659 \\
\hline
\end{tabular}


Table B11. Experiment II chemical properties descriptive statistics WV16

\begin{tabular}{|c|c|c|c|c|c|c|}
\hline Indicator & Mean & $\begin{array}{l}\text { Standard } \\
\text { Deviation }\end{array}$ & $\begin{array}{c}\text { Standard } \\
\text { Error }\end{array}$ & Mode & Minimum & Maximum \\
\hline OM (mg kg-1) & 55.086 & 9.450 & 1.337 & 50.100 & 36.500 & 82.000 \\
\hline pH & 6.153 & 0.765 & 0.108 & 5.460 & 5.010 & 7.630 \\
\hline $\mathrm{Al}\left(\mathrm{mg} \mathrm{kg} \mathbf{k g}^{-1}\right)$ & 541.015 & 173.057 & 24.474 & . & 274.500 & 1095.000 \\
\hline $\left.\mathrm{Ca}(\mathrm{mg} \mathrm{kg})^{-1}\right)$ & 1752.680 & 867.654 & 122.705 & . & 569.700 & 5567.000 \\
\hline $\mathrm{Fe}\left(\mathrm{mg} \mathrm{kg} \mathrm{kg}^{-1}\right)$ & 83.447 & 36.252 & 5.127 & . & 36.820 & 182.900 \\
\hline K $\left(\mathbf{m g ~ k g}{ }^{-1}\right)$ & 97.775 & 34.483 & 4.877 & . & 45.310 & 191.420 \\
\hline $\operatorname{Mg}\left(m g k^{-1}\right)$ & 134.663 & 27.264 & 3.856 & 119.300 & 64.750 & 205.160 \\
\hline $\mathrm{Na}\left(\mathrm{mg} \mathrm{kg} \mathrm{g}^{-1}\right)$ & 79.402 & 22.639 & 3.202 & . & 48.990 & 169.370 \\
\hline P (mg kg-1) & 5.313 & 2.244 & 0.317 & 3.770 & 1.770 & 10.900 \\
\hline $\mathrm{Zn}\left(\mathrm{mg} \mathrm{kg} \mathbf{~}^{-1}\right)$ & 1.643 & 0.622 & 0.088 & 1.260 & 0.780 & 3.490 \\
\hline
\end{tabular}


Table B12. Experiment II \% vegetation descriptive statistics WV16

\begin{tabular}{|c|c|c|c|c|c|c|}
\hline Indicator & Mean & $\begin{array}{l}\text { Standard } \\
\text { Deviation }\end{array}$ & $\begin{array}{c}\text { Standard } \\
\text { Error }\end{array}$ & Mode & Minimum & Maximum \\
\hline Surface Cover 2017 & 99.98 & 0.14 & 0.02 & 100.00 & 99.00 & 100.00 \\
\hline Dead Material 2017 & 11.20 & 6.40 & 0.90 & 6.00 & 0.00 & 24.00 \\
\hline Moss 2017 & 0.68 & 0.47 & 0.07 & 1.00 & 0.00 & 1.00 \\
\hline Canopy Cover 2017 & 86.38 & 11.39 & 1.61 & 94.00 & 25.00 & 100.00 \\
\hline Legumes 2017 & 37.20 & 16.58 & 2.34 & 28.00 & 5.00 & 81.00 \\
\hline Forbs 2017 & 18.62 & 13.92 & 1.97 & 0.00 & 0.00 & 54.00 \\
\hline Grass 2017 & 30.62 & 15.31 & 2.17 & 26.00 & 3.00 & 71.00 \\
\hline Moss Only 2017 & 2.68 & 6.61 & 0.93 & 0.00 & 0.00 & 32.00 \\
\hline Bare Soil 2017 & 0.02 & 0.14 & 0.02 & 0.00 & 0.00 & 1.00 \\
\hline Surface Cover 2018 & 98.00 & 14.14 & 2.00 & 100.00 & 0.00 & 100.00 \\
\hline Dead Material 2018 & 7.64 & 16.30 & 2.31 & 0.00 & 0.00 & 84.00 \\
\hline Moss 2018 & 0.70 & 0.46 & 0.07 & 1.00 & 0.00 & 1.00 \\
\hline Canopy Cover 2018 & 84.42 & 24.87 & 3.52 & 100.00 & 0.00 & 100.00 \\
\hline Legumes 2018 & 24.08 & 15.93 & 2.25 & 13.00 & 0.00 & 81.00 \\
\hline Forbs 2018 & 18.02 & 18.03 & 2.55 & 0.00 & 0.00 & 70.00 \\
\hline Grass 2018 & 46.68 & 21.01 & 2.97 & 64.00 & 0.00 & 85.00 \\
\hline Moss Only 2018 & 1.64 & 3.11 & 0.44 & 0.00 & 0.00 & 10.00 \\
\hline Bare Soil 2018 & 2.00 & 14.14 & 2.00 & 0.00 & 0.00 & 100.00 \\
\hline
\end{tabular}


APPENDIX C

Table C1. Descriptive statistics and analysis of variance for particle size distribution

\begin{tabular}{|c|c|c|c|}
\hline & Sand & $\begin{array}{c}\text { Silt } \\
\mathrm{mg} / \mathrm{kg}\end{array}$ & Clay \\
\hline \multicolumn{4}{|l|}{ Treatment } \\
\hline No Fertilizer & $234^{\mathrm{a}}$ & $494^{\mathrm{a}}$ & $273^{\mathrm{a}}$ \\
\hline Fertilizer & $236^{\mathrm{a}}$ & $499^{\mathrm{a}}$ & $265^{\mathrm{a}}$ \\
\hline \multicolumn{4}{|l|}{ Block } \\
\hline 1 & $246^{\mathrm{a}}$ & $509^{a}$ & $258^{\mathrm{b}}$ \\
\hline 2 & $226^{\mathrm{b}}$ & $499^{a}$ & $275^{\mathrm{a}}$ \\
\hline 3 & $233^{\mathrm{ab}}$ & $480^{\mathrm{b}}$ & $274^{\mathrm{a}}$ \\
\hline \multicolumn{4}{|l|}{ Site } \\
\hline WV2 & $182 \pm 27^{\mathrm{c}^{*}}$ & $533 \pm 60^{\mathrm{a}}$ & $285 \pm 40^{\mathrm{a}}$ \\
\hline WV11 & $251 \pm 29^{b}$ & $490 \pm 15^{b}$ & $259 \pm 17^{b}$ \\
\hline WV16 & $272 \pm 53^{\mathrm{a}}$ & $465 \pm 35^{\mathrm{c}}$ & $262 \pm 32^{b}$ \\
\hline \multicolumn{4}{|l|}{ Year } \\
\hline 2017 & $233 \pm 54^{\mathrm{a}}$ & $497 \pm 63^{a}$ & $270 \pm 35^{\mathrm{a}}$ \\
\hline 2018 & $237 \pm 55^{\mathrm{a}}$ & $496 \pm 32^{\mathrm{a}}$ & $268 \pm 31^{\mathrm{a}}$ \\
\hline \multirow[t]{2}{*}{ Grand Mean } & 235 & 496 & 269 \\
\hline & & $-\operatorname{Pr}>$ F-- & \\
\hline Treatment & 0.7425 & 0.4937 & 0.1676 \\
\hline Block & 0.0569 & 0.0067 & 0.0162 \\
\hline Site & $<0.0001$ & $<0.0001$ & 0.0002 \\
\hline Year & 0.6484 & 0.9001 & 0.6650 \\
\hline
\end{tabular}

Same letters in the same columns indicate no statistically significant differences at $\mathrm{P}<0.10 .{ }^{*}$ Average \pm Standard Deviation 
Table C2. Descriptive statistics and analysis of variance for available nutrients

\begin{tabular}{|c|c|c|c|c|c|c|c|c|}
\hline & Al & $\mathbf{C a}$ & $\mathrm{Fe}$ & $\mathbf{K}$ & $\mathrm{Mg}$ & $\mathbf{N a}$ & $\mathbf{P}$ & $\mathbf{Z n}$ \\
\hline & \multicolumn{8}{|c|}{$\mathrm{mg} \mathrm{kg}^{-1}$} \\
\hline \multicolumn{9}{|l|}{ Treatment } \\
\hline No Fertilizer & $506^{\mathrm{a}}$ & $1255^{\mathrm{a}}$ & $74^{\mathrm{a}}$ & $91^{\mathrm{a}}$ & $151^{\mathrm{a}}$ & $75^{\mathrm{a}}$ & $4.08^{\mathrm{a}}$ & $1.41^{\mathrm{a}}$ \\
\hline Fertilizer & $481^{\mathrm{a}}$ & $1287^{\mathrm{a}}$ & $76^{\mathrm{a}}$ & $91^{\mathrm{a}}$ & $147^{\mathrm{a}}$ & $75^{\mathrm{a}}$ & $4.50^{\mathrm{a}}$ & $1.44^{\mathrm{a}}$ \\
\hline \multicolumn{9}{|l|}{ Block } \\
\hline 1 & $488^{b}$ & $991^{\mathrm{c}}$ & $74^{\mathrm{b}}$ & $92^{\mathrm{a}}$ & $132^{\mathrm{c}}$ & $74^{\mathrm{a}}$ & $3.74^{\mathrm{b}}$ & $1.29^{\mathrm{b}}$ \\
\hline 2 & $454^{\mathrm{b}}$ & $1241^{b}$ & $66^{c}$ & $94^{\mathrm{a}}$ & $150^{\mathrm{b}}$ & $73^{\mathrm{a}}$ & $4.08^{b}$ & $1.29^{\mathrm{b}}$ \\
\hline 3 & $538^{a}$ & $1582^{\mathrm{a}}$ & $86^{\mathrm{a}}$ & $87^{\mathrm{a}}$ & $166^{\mathrm{a}}$ & $78^{\mathrm{a}}$ & $5.06^{\mathrm{a}}$ & $1.70^{\mathrm{a}}$ \\
\hline \multicolumn{9}{|l|}{ Site } \\
\hline WV2 & $452 \pm 56^{\mathrm{c}^{*}}$ & $1257 \pm 367^{b}$ & $75 \pm 16^{b}$ & $92 \pm 27^{\mathrm{a}}$ & $195 \pm 29^{a}$ & $82 \pm 31^{a}$ & $4.26 \pm 1.15^{\mathrm{a}}$ & $1.57 \pm 0.40^{\mathrm{a}}$ \\
\hline WV11 & $490 \pm 54^{\mathrm{b}}$ & $976 \pm 253^{c}$ & $62 \pm 8^{c}$ & $101 \pm 24^{\mathrm{a}}$ & $126 \pm 32^{b}$ & $71 \pm 10^{\mathrm{b}}$ & $4.27 \pm 2.18^{\mathrm{a}}$ & $1.11 \pm 0.25^{\mathrm{b}}$ \\
\hline WV16 & $538 \pm 159^{a}$ & $1582 \pm 1049^{a}$ & $88 \pm 32^{a}$ & $81 \pm 21^{b}$ & $126 \pm 16^{\mathrm{a}}$ & $73 \pm 9^{\mathrm{b}}$ & $4.35 \pm 1.47^{\mathrm{a}}$ & $1.59 \pm 0.61^{\mathrm{a}}$ \\
\hline \multicolumn{9}{|l|}{ Year } \\
\hline 2017 & $478 \pm 72^{\mathrm{a}}$ & $1190 \pm 448^{a}$ & $71 \pm 18^{\mathrm{b}}$ & $86 \pm 28^{b}$ & $146 \pm 40^{\mathrm{a}}$ & $69 \pm 16^{\mathrm{b}}$ & $3.93 \pm 1.72^{\mathrm{b}}$ & $1.30 \pm 0.50^{\mathrm{b}}$ \\
\hline 2018 & $508 \pm 132^{\mathrm{a}}$ & $1353 \pm 877^{a}$ & $79 \pm 27^{\mathrm{a}}$ & $96 \pm 21^{\mathrm{a}}$ & $152 \pm 44^{\mathrm{a}}$ & $82 \pm 21^{a}$ & $4.65 \pm 1.49^{\mathrm{a}}$ & $1.54 \pm 0.47^{\mathrm{a}}$ \\
\hline Grand Mean & 493 & 1271 & 75 & 91 & 149 & 75 & 4.29 & 1.42 \\
\hline
\end{tabular}




\begin{tabular}{lcccccccc} 
Treatment & 0.1712 & 0.7939 & 0.5888 & 0.9294 & 0.4179 & 0.8628 & 0.1563 & 0.6318 \\
Block & 0.0012 & 0.0006 & 0.0002 & 0.4473 & $<0.0001$ & 0.5412 & 0.0013 & $<0.0001$ \\
Site & 0.0009 & 0.0004 & $<0.0001$ & 0.0037 & $<0.0001$ & 0.0312 & 0.9646 & $<0.0001$ \\
Year & 0.1048 & 0.1786 & 0.0233 & 0.0217 & 0.1224 & 0.0003 & 0.0164 & 0.0017 \\
\hline
\end{tabular}

Same letters in the same columns indicate no statistically significant differences at $\mathrm{P}<0.10$. *Average \pm Standard Deviation

Table C3. Descriptive statistics and analysis of variance for available nutrients

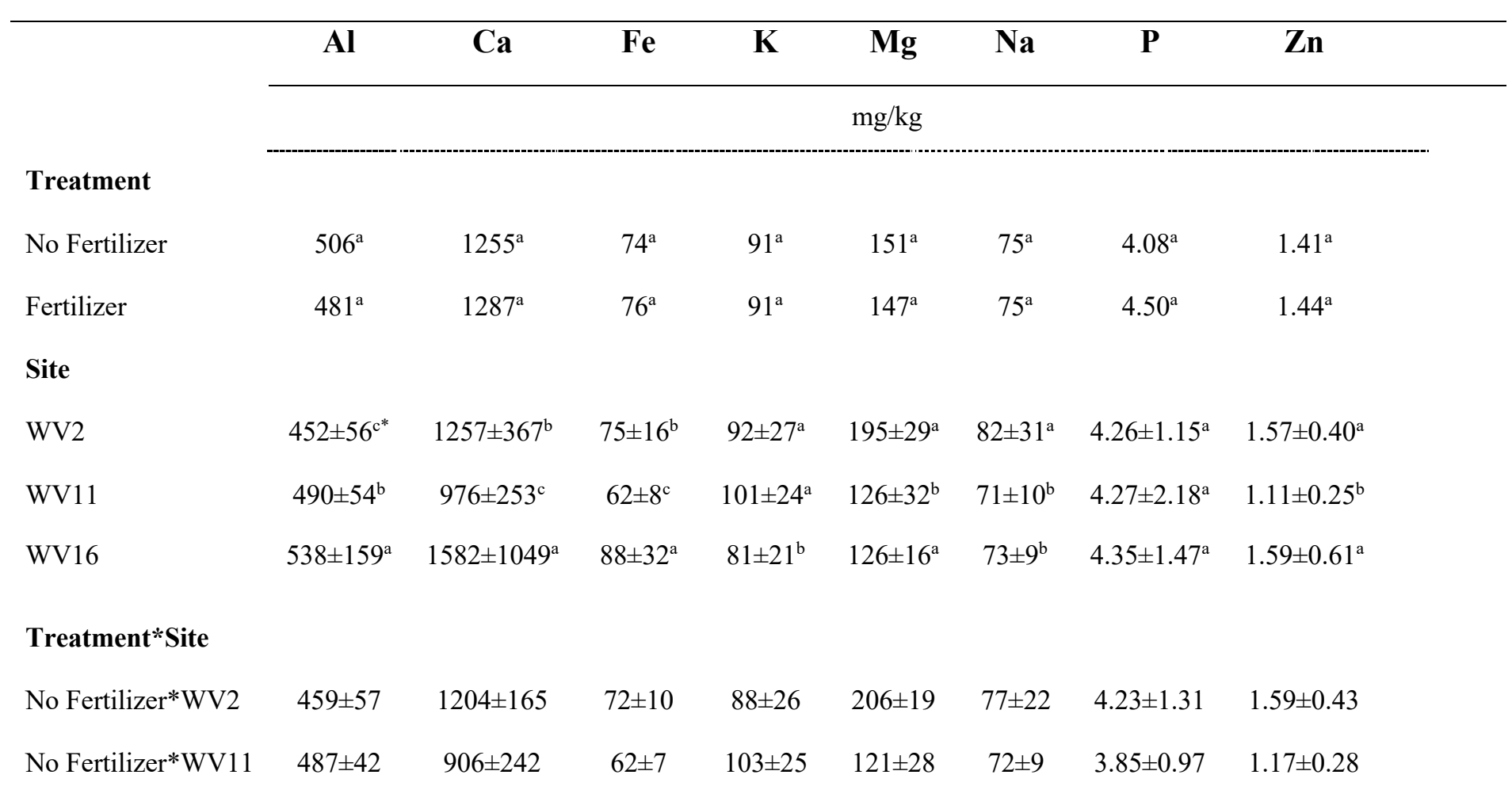




\begin{tabular}{lcccccccc} 
No Fertilizer*WV16 & $571 \pm 181$ & $1656 \pm 1435$ & $89 \pm 36$ & $81 \pm 20$ & $125 \pm 20$ & $76 \pm 7$ & $4.17 \pm 1.74$ & $1.46 \pm 0.53$ \\
Fertilizer*WV2 & $445 \pm 55$ & $1309 \pm 495$ & $78 \pm 20$ & $95 \pm 28$ & $185 \pm 33$ & $87 \pm 38$ & $4.28 \pm 1.01$ & $1.55 \pm 0.38$ \\
Fertilizer*WV11 & $492 \pm 65$ & $1045 \pm 250$ & $62 \pm 9$ & $98 \pm 24$ & $131 \pm 36$ & $69 \pm 12$ & $4.70 \pm 2.90$ & $1.05 \pm 0.21$ \\
Fertilizer*WV16 & $505 \pm 131$ & $1508 \pm 442$ & $88 \pm 29$ & $81 \pm 22$ & $127 \pm 11$ & $71 \pm 10$ & $4.53 \pm 1.16$ & $1.73 \pm 0.67$ \\
Grand Mean & 493 & 1271 & 75 & 91 & 149 & 75 & 4.29 & 1.42 \\
& & & & & & & & \\
& & & & $------------------\operatorname{Pr}>$ F-------------------- & \\
Treatment & 0.1712 & 0.7939 & 0.5888 & 0.9294 & 0.4179 & 0.8628 & 0.1563 & 0.6318 \\
Site & 0.0009 & 0.0004 & $<0.0001$ & 0.0037 & $<0.0001$ & 0.0312 & 0.9646 & $<0.0001$ \\
Treatment*Site & 0.2596 & 0.5719 & 0.7134 & 0.5210 & 0.0086 & 0.1819 & 0.5438 & 0.0699 \\
\hline
\end{tabular}

Same letters in the same columns indicate no statistically significant differences at $\mathrm{P}<0.10$. *Average \pm Standard Deviation 